\title{
Arbeidsmarktmonitor Metalektro 2014
}

Citation for published version (APA):

Gerards, R., de Grip, A., de Hoon, M. L. A., Künn-Nelen, A. C., \& Poulissen, D. (2015).

Arbeidsmarktmonitor Metalektro 2014. ROA. ROA Reports No. 002

https://doi.org/10.26481/umarep.2015002

Document status and date:

Published: 01/01/2015

DOI:

10.26481/umarep.2015002

Document Version:

Publisher's PDF, also known as Version of record

\section{Please check the document version of this publication:}

- A submitted manuscript is the version of the article upon submission and before peer-review. There can be important differences between the submitted version and the official published version of record.

People interested in the research are advised to contact the author for the final version of the publication, or visit the DOI to the publisher's website.

- The final author version and the galley proof are versions of the publication after peer review.

- The final published version features the final layout of the paper including the volume, issue and page numbers.

Link to publication

\footnotetext{
General rights rights.

- You may freely distribute the URL identifying the publication in the public portal. please follow below link for the End User Agreement:

www.umlib.nl/taverne-license

Take down policy

If you believe that this document breaches copyright please contact us at:

repository@maastrichtuniversity.nl

providing details and we will investigate your claim.
}

Copyright and moral rights for the publications made accessible in the public portal are retained by the authors and/or other copyright owners and it is a condition of accessing publications that users recognise and abide by the legal requirements associated with these

- Users may download and print one copy of any publication from the public portal for the purpose of private study or research.

- You may not further distribute the material or use it for any profit-making activity or commercial gain

If the publication is distributed under the terms of Article $25 \mathrm{fa}$ of the Dutch Copyright Act, indicated by the "Taverne" license above, 


\section{ARBEIDSMARKTMONITOR METALEKTRO 2014}

ROA-R-2015/2

Ruud Gerards

Andries de Grip

Marloes de Hoon

Annemarie Künn-Nelen

Davey Poulissen

De Arbeidsmarktmonitor wordt mede mogelijk gemaakt door een bijdrage vanuit het Europees Sociaal Fonds (ESF) 


\section{Colofon}

(C) Researchcentrum voor Onderwijs en Arbeidsmarkt (ROA). Niets uit deze uitgave mag op enige manier worden verveelvoudigd zonder voorafgaande schriftelijke toestemming van de directeur van het ROA.

\section{Researchcentrum voor Onderwijs en Arbeidsmarkt}

School of Business and Economics

Maastricht University

\section{Vormgeving}

ROA secretariaat, Maastricht

\section{Verkoop}

Researchcentrum voor Onderwijs en Arbeidsmarkt email: secretary-roa-sbe@maastrichtuniversity.nl

website: www.roa.nl

ISBN: 978-90-5321-539-5 


\section{INHOUD}

\section{Voorwoord}

Management summary

01 Dynamiek in de Metalektro 1

1.1 Positieve conjunctuurontwikkelingen in de Metalektro 2

1.2 Werkgelegenheid in de Metalektro licht gestegen 3

1.3 Vergrijzing in de Metalektro 5

1.4 Gemiddelde opleidingsniveau in de Metalektro verder gestegen 6

1.5 Innovaties in de Metalektro vooral gericht op verbeteringen van producten, processen en diensten $\quad 7$

02 Arbeidsmarktontwikkelingen Metalektro 2014

2.1 Per saldo meer bedrijven met instroom dan bedrijven met uitstroom van personeel

2.2 Eventuele krimp in werkgelegenheid voornamelijk opgevangen met flexibele schil

2.3 Daling in omvang flexibele schil na bereiken van record in juli 2014

2.4 Kleine krimp in de flexibele schil in 2e helft 2014 betrof vooral uitvoerende en ondersteunende technici

03 Vacatures en werving

3.1 Percentage bedrijven met vacatures relatief stabiel in 2014

3.2 Toename van hoeveelheid werk belangrijkste ontstaansreden vacatures

3.3 Grote verschillen in gebruik en effectiviteit van wervingskanalen

3.4 Internetwerving populairder en effectiever voor werving van hoger opgeleide technici

3.5 Linkedln populairste sociale mediakanaal voor werven van technici

3.6 Weer minder bedrijven met wervingsproblemen in 2014

3.7 De oorzaken en gevolgen van wervingsproblemen

3.8 Aanpassingen in werving en selectie om moeilijk vervulbare vacatures op te vullen

3.9 Interne aanpassingen om moeilijk vervulbare vacatures op te vullen 
4.2 Aantal dagen besteed aan opleiding ook gestegen 45

4.3 Initiatief voor trainingen en stimuleren van betrokkenheid personeel $\quad 46$

4.4 Meeste trainingen vaktechnisch, sterke toename in veiligheidstrainingen $\quad 49$

4.5 Helft van de bedrijven ervaart (geen) belemmeringen bij scholing technisch personeel

4.6 Gebruik HR-instrumenten in 2014

05 Organisatie van het werk binnen de Metalektro

5.1 Vaakst genoemde organisatorische verandering is de variabele inzet van technisch personeel

5.2 Behoefte van bedrijven aan breed inzetbaar personeel verschilt sterk per functiecategorie

5.3 Arbeidsautonomie in de Nederlandse Metalektro: een vergelijking met andere landen en sectoren

5.4 Externe samenwerking als organisatorische verandering

06 Vergrijzing en duurzame inzetbaarheid

6.1 Leeftijdsopbouw Metalektro

6.2 Vervangingsproblemen

6.3 Duurzame inzetbaarheid

6.4 Voorkomen en beperken van vervangingsproblemen

07 Metalektro in de toekomst

7.1 Bedrijven positief over verwachte ontwikkeling werkgelegenheid

7.2 Verwachte werkgelegenheidsontwikkeling verschilt tussen MKB-bedrijven en grote bedrijven

7.3 Het belang van gedragsmatige competenties voor technische functies blijft toenemen

7.4 Bevorderen van de inzetbaarheid van het personeel belangrijkste speerpunt voor de komende jaren

7.5 Functioneringsgesprek populairste instrument voor realiseren speerpunten

7.6 Knelpunten van speerpunten

08 Agenda voor de toekomst

8.1 Positieve economische ontwikkelingen en een lichte werkgelegenheidsgroei

8.2 Eisen aan personeel worden hoger: de sector beweegt naar een 'smart industry'

8.3 Welke knelpunten en uitdagingen ervaren bedrijven bij de ontwikkeling van hun personeel?

8.4 Hoe faciliteren en motiveren bedrijven hun werknemers om zich te ontwikkelen?

8.5 Concluderend: In de ontwikkeling naar een 'smart industry' neemt de rol van de HR afdeling toe 


\section{VOORWOORD}

Met genoegen bieden de auteurs van het Researchcentrum voor Onderwijs en Arbeidsmarkt (ROA) en opdrachtgever Stichting $\mathrm{A}+\mathrm{O}$ Metalektro u de Arbeidsmarktmonitor Metalektro 2014 aan. De monitor bevat analyses van de actuele en toekomstige ontwikkelingen op personeels- en arbeidsmarktgebied in de Nederlandse Metalektro. De uitkomsten van deze analyses kunnen als input dienen bij het ontwikkelen van personeels- en arbeidsmarktbeleid door metalektrobedrijven, de sociale partners en andere partijen.

De rapportage die voor u ligt vormt het sluitstuk van een onderzoek waarbij gedurende een heel jaar op verschillende momenten gegevens zijn verzameld. De hoofdmoot van de bevindingen in de Arbeidsmarktmonitor Metalektro is gebaseerd op de uitgebreide internetvragenlijst die in 2014 aan het begin van ieder kwartaal door het werkgeverspanel is ingevuld. In elke meting zijn vragen beantwoord met betrekking tot de in- en uitstroom en vacatures. Hierop is de werkgelegenheidsbarometer gebaseerd. Daarnaast was in 2014 een aantal centrale thema's verdeeld over vier vragenlijsten. Om meer duiding te kunnen bieden bij de bevindingen uit de vragenlijsten is ook een aantal metalektrobedrijven geïnterviewd. Tot slot is voor verdieping en verbreding gebruik gemaakt van gegevens afkomstig van het CBS, PME en de European Social Survey.

Wij willen op deze plaats alle bedrijven die de vragenlijsten hebben ingevuld bedanken voor hun bijdrage aan de monitor en hopen dat het rapport en de bedrijfsscan die zij ontvangen hen waardevolle benchmarkinformatie oplevert. Een speciaal woord van dank is daarbij gericht aan de bedrijven die bereid waren om deel te nemen aan de verdiepende gesprekken. Het expertpanel, bestaande uit Monique de Haan en Manon Lubbers (Stichting A+O Metalektro), Willie Berentsen en Rien Smit (FME-CWM), Ruud van den Bergh (FNV Bondgenoten), Pjotr Hoekstra (Boon Edam), Henk Meeuwissen (CSI), Jacqueline van Gessel (Bosch) en Jaap Blankestijn (Thales) wordt hartelijk bedankt voor hun constructieve feedback. Het veldwerk, de dataverzameling- en verwerking voor deze monitor zijn verricht door Sander Dijksman (ROA). 



\section{MANAGEMENT SUMMARY}

Het economisch herstel dat in de Metalektro vanaf 2013 duidelijk te zien is, heeft zich in 2014 zichtbaar doorgezet. De positieve ontwikkeling van de omzet en de conjunctuurindicatoren vertalen zich ook in een toename van de werkgelegenheid. In 2014 waren er in alle kwartalen meer bedrijven die hun werkgelegenheid zagen toenemen dan bedrijven die hun werkgelegenheid zagen afnemen (Hoofdstuk 1). Per saldo was er over 2014 als geheel een overschot van bedrijven met een instroom van nieuwe medewerkers, maar dit komt volledig op conto van de eerste helft van het jaar toen het percentage bedrijven met instroom het percentage bedrijven met uitstroom ruimschoots overtrof. In de tweede helft van het jaar was het percentage bedrijven met instroom van nieuwe medewerkers vrijwel gelijk aan het percentage bedrijven met uitstroom. Het grootste overwicht van bedrijven met instroom over bedrijven met uitstroom vinden we over heel 2014 bezien bij de engineering en R\&D functies, waar relatief gezien de sterkste netto instroom plaats vond. In de eerste helft van 2014 groeide ook de flexibele schil sterk, vooral door een toename van het aantal medewerkers met een tijdelijk contract. In de tweede helft van het jaar kromp de flexibele schil echter weer door een afname van het percentage tijdelijke contracten. Signalen van bedrijven uit de sector wijzen er op dat een deel van de tijdelijke contracten in vaste contracten is omgezet als gevolg van de tot dan toe aanhoudende positieve economische ontwikkelingen (Hoofdstuk 2).

\section{Werving van personeel}

Vacatures ontstonden in 2014 vooral door de toename van het werk. Hoewel vacatures met name in de laatste maanden van 2014 gemiddeld iets langer open blijken te staan, is er een lichte afname van de wervingsproblemen die de bedrijven ervaren. Mogelijk komt dit doordat vacatures steeds vaker in een vroeg stadium proactief worden geopend. De wervingsproblemen die er zijn, concentreren zich met name op de uitvoerende technische functies en de engineering en R\&D functies en worden vooral toegeschreven aan het feit dat de sollicitanten over onvoldoende competenties beschikken. Om met moeilijk vervulbare vacatures om te gaan, zetten metalektrobedrijven hun huidige personeel vaak flexibel in of laten ze hun medewerkers overuren draaien. Mede als gevolg hiervan geven bedrijven aan dat wervingsproblemen veelal leiden tot een toename van de werkdruk. 
De meest gebruikte en effectiefste wervingskanalen waren net als in voorgaande jaren het uitzendbureau (voor lager en middelbaar opgeleide technici) en het commercieel werving- en selectiebureau (voor hoger opgeleide technici). Het gebruik van online vacaturebanken en sociale media voor de werving van nieuw personeel speelt bij de meeste bedrijven hooguit een bijrol in het scala aan beschikbare wervingskanalen. Hoofdstuk 3 gaat uitgebreid in op het thema werving.

\section{Opleidingsinspanningen, competenties en speerpunten toekomstig personeelsbeleid}

Voor het eerst sinds 2009 stegen in 2014 de gemiddelde out-of-pocket uitgaven van metalektrobedrijven aan opleiding en training voor technische medewerkers. Ook het gemiddeld aantal dagen training per werknemer steeg in 2014. De stijging in de trainingsdeelname is bijzonder sterk bij de medewerkers in de flexibele schil. Hoewel het trainen van de flexibele schil hiermee een flinke inhaalslag heeft gemaakt, worden vaste medewerkers nog altijd meer getraind dan medewerkers met een tijdelijk contract, die op hun beurt weer vaker training ontvangen dan ingeleende medewerkers. De stijgende uitgaven aan opleiding en training zien we op vrijwel alle trainingsgebieden terug. De toename is het grootst voor trainingen in veilig gedrag en trainingen in communicatieve vaardigheden. Ook werden in 2014 bij meer metalektrobedrijven dan in 2013 trainingen gegeven in andere 'soft skills' zoals plannen en organiseren, werken in teamverband, procesgericht werken en commerciële vaardigheden (zie Hoofdstuk 4). Dit onderstreept het nog altijd stijgende belang van gedragsmatige competenties, in de Metalektro ook wel PROFI competenties genoemd: Probleemoplossend vermogen, Relatie met klanten, Omgaan met veranderingen, Flexibiliteit en Initiatief. Een meerderheid van de bedrijven denkt dat deze gedragsmatige competenties in de toekomst nog belangrijker worden dan ze al zijn. Het verder ontwikkelen van deze competenties bij medewerkers draagt bij aan het realiseren van het populairste speerpunt van het personeelsbeleid van metalektrobedrijven: het bevorderen van de inzetbaarheid van het personeel (Hoofdstuk 7). Het initiatief voor trainingen werd zoals in voorgaande jaren in de meeste gevallen genomen door de leidinggevende en werknemer samen, maar het belang van de afdeling HR bij het initiëren van trainingen en cursussen neemt toe.

\section{Vervangingsproblematiek en duurzame inzetbaarheid}

Het personeel in de Metalektro ontgroent en vergrijst. Hoewel de gemiddelde leeftijd van de werkenden in de sector al sinds jaren onafgebroken toeneemt en in 2014 op 44,7 jaar lag, blijven de door de bedrijven voor de komende jaren verwachte vervangingsproblemen van personeel dat met pensioen gaat afnemen. Een mogelijke verklaring voor deze paradox ligt in de verplaatsing van werkzaamheden naar het buitenland of automatisering of robotisering van werkzaamheden. Daarnaast is het mogelijk dat pensioenuitstroom wordt gebruikt om een natuurlijk verlopende krimp vorm te geven, door niet al het uittredende personeel te vervangen. Bedrijven zijn nu echter ook beter ingesteld en voorbereid op de verwachte uitstroom van medewerkers die met pensioen gaan (Hoofdstuk 6). De helft van de metalektrobedrijven nam één of meerdere maatregelen 
die specifiek gericht waren op het beperken van de verwachte vervangingsproblemen. Daarbij was het aannemen en zelf opleiden van nieuwe werknemers het meest populair. Daarnaast hebben steeds meer metalektrobedrijven aandacht voor de duurzame inzetbaarheid van hun personeel. Dit uit zich in een toenemend gebruik van active-aging instrumenten zoals het breder inzetbaar maken van medewerkers en aandacht voor hun (fysieke) belasting.

\section{Technologische innovaties en organisatorische veranderingen}

De meeste metalektrobedrijven realiseerden ook in 2014 weer innovaties. Deze innovaties zijn momenteel, maar ook in de nabije toekomst meer gericht op verbetering van bestaande producten, processen en diensten, dan op compleet nieuwe producten of productieprocessen. Daarnaast heeft een kleine meerderheid van de bedrijven in 2014 één of meerdere organisatorische veranderingen doorgevoerd. Evenals in voorgaande jaren concentreerden organisatorische veranderingen zich in 2014 niet zozeer op de manier waarop het bedrijf wordt geleid, maar vooral op de manier waarop het werk wordt georganiseerd. Voor de komende drie jaar worden de variabele inzet van het eigen technisch personeel en het projectmatig werken het meest genoemd als verwachte organisatorische vernieuwingen (Hoofdstuk 5).

\section{Agenda voor de Toekomst}

Eind 2014 heeft de Nederlandse maakindustrie de Actieagenda Smart Industry gelanceerd. 'Smart industry' is daarbij de verzamelnaam die een aantal trends samenvat die al enige tijd gaande zijn in de Metalektro en waarvan verwacht kan worden dat ze de komende jaren verder door zullen zetten. Deze trends zijn onder meer de snelle technologische ontwikkeling in bijvoorbeeld robotica en sensortechnologie, de toenemende samenwerking van bedrijven in ketens en netwerken en de alsmaar stijgende eisen die mede hierdoor aan het personeel in de Metalektro gesteld worden. Dit is bijvoorbeeld zichtbaar in het percentage hoog opgeleiden in de sector - dat in 2014 toenam tot $28 \%$ van alle medewerkers (Hoofdstuk 1 ) - en aan het hoge percentage bedrijven dat verwacht dat gedragsmatige competenties in de toekomst nog belangrijker worden (Hoofdstuk 7). Ook heeft bijna 70\% van de metalektrobedrijven in (zeer) sterke mate behoefte aan breed inzetbare uitvoerende technici, waarbij $47 \%$ van de bedrijven 'product- en/of procesvernieuwing' als één van de redenen noemt voor de behoefte aan breed inzetbare technici (Hoofdstuk 5).

Dit illustreert dat de beweging naar een 'smart industry' de stuwende kracht is onder de toenemende vraag naar hoger opgeleiden, PROFI skills en brede inzetbaarheid. Human capital is hiermee de motor van de sector geworden. Voor de bedrijven is het essentieel dat hun personeel zo goed mogelijk mee komt, en mee wordt genomen, met deze beweging richting een 'smart industry'. Dit geldt vanzelfsprekend ook voor de medewerkers zelf. Tot op heden is deze brede inzetbaarheid echter een punt waarop nog veel bedrijven knelpunten ervaren. Bedrijven geven bijvoorbeeld aan dat het verbeteren van 
de inzetbaarheid nogal eens belemmerd wordt doordat medewerkers vaak moeilijk kunnen omgaan met veranderingen of onvoldoende bereid zijn in zichzelf te investeren. Ook wervingsproblemen en de vergrijzing kunnen een knelpunt vormen in de beweging naar een 'smart industry'.

Metalektrobedrijven proberen hun werknemers op verschillende manieren te faciliteren en motiveren om zich te blijven ontwikkelen. Zo proberen steeds meer bedrijven een leerrijke werkomgeving te creëren en hebben steeds meer bedrijven aandacht voor duurzame inzetbaarheid en vervangingsproblemen. Daarbij komt het initiatief voor het volgen van trainingen steeds vaker bij de HR afdeling te liggen. Momenteel biedt bijna 90\% van de metalektrobedrijven zijn medewerkers trainingen aan in vaktechnische kennis en vaardigheden. De investeringen in trainingen en opleidingen namen in 2014 licht toe, net als de aandacht voor de ontwikkeling van 'soft skills', maar beide blijven achter bij wat nodig lijkt te zijn voor de ontwikkeling tot een 'smart industry'. Ook zien we dat bedrijven doorgaans veel minder aandacht besteden aan het op peil houden van de kennis en vaardigheden van medewerkers in de flexibele schil dan bij de medewerkers die in vaste dienst zijn, hoewel de verschillen de afgelopen twee jaar wel kleiner zijn geworden. Door de cruciale rol die het human capital speelt in de beweging naar een 'smart industry' zal de rol van de HR afdeling de komende jaren alleen nog maar toenemen en zal de concurrentiekracht van de bedrijven in de Metalektro in toenemende mate worden bepaald door de professionaliteit van het gevoerde HR-beleid. 


\section{1 \\ DYNAMIEK \\ IN DE METALEKTRO}

Het economisch herstel dat in de Metalektro vanaf 2013 duidelijk te zien is heeft zich in 2014 zichtbaar doorgezet. De positieve ontwikkeling van de omzet en de conjunctuurindicatoren vertalen zich ook in een toename van de werkgelegenheid. In 2014 waren er in alle kwartalen meer bedrijven die hun werkgelegenheid zagen toenemen dan bedrijven die hun werkgelegenheid zagen afnemen. Ook cijfers van de Raad van Overleg Metalektro (ROM) bevestigen een (licht) gestegen werkgelegenheid in de Metalektro. Een grote meerderheid van de metalektrobedrijven realiseerde ook in 2014 weer innovaties. Deze zijn momenteel en in de nabije toekomst meer gericht op verbetering van bestaande producten, processen en diensten, dan op compleet nieuwe ontwikkelingen. Ten slotte zijn zowel de gemiddelde leeftijd als het gemiddelde opleidingsniveau van de werknemers in de sector verder gestegen. Het aandeel hoger opgeleiden is weer verder toegenomen. 


\subsection{Positieve conjunctuurontwikkelingen in de Metalektro}

Het economisch herstel dat in de Metalektro vanaf 2013 duidelijk te zien is heeft in 2014 zichtbaar doorgezet. Figuur 1.1 laat zien dat de sector in alle kwartalen van 2014 een positieve omzetgroei heeft gerealiseerd. $\mathrm{Na}$ een sterk eerste kwartaal met $8 \%$ omzetgroei kende de sector drie kwartalen op rij met ruim boven de $3 \%$ groei. De Metalektro is een van de sectoren die nadrukkelijk profijt heeft van de stijgende Nederlandse export. Volgens het CBS conjunctuurbericht van 13 februari 2015 groeide de export in het vierde kwartaal van 2014 met 4,4\%. Het CBS noemt hierbij nadrukkelijk de belangrijke bijdrage van gestegen uitvoer van vervoermiddelen, metaal(producten) en machines.' Ook uit de meeste oudere conjunctuurberichten die over de eerdere maanden en kwartalen van 2014 gaan, blijkt dat de export in bijna alle maanden van 2014 is gestegen ten opzichte van 2013 en dat industriële producten, machines en vervoermiddelen hierin een sleutelrol speelden. Als een van de uitzonderingen geldt de maand mei 2014, waarin de totale Nederlandse exportwaarde lager was dan in mei 2013, maar waarin de uitvoer van industriële producten, machines en transportmiddelen wél hoger was dan in mei 2013.²

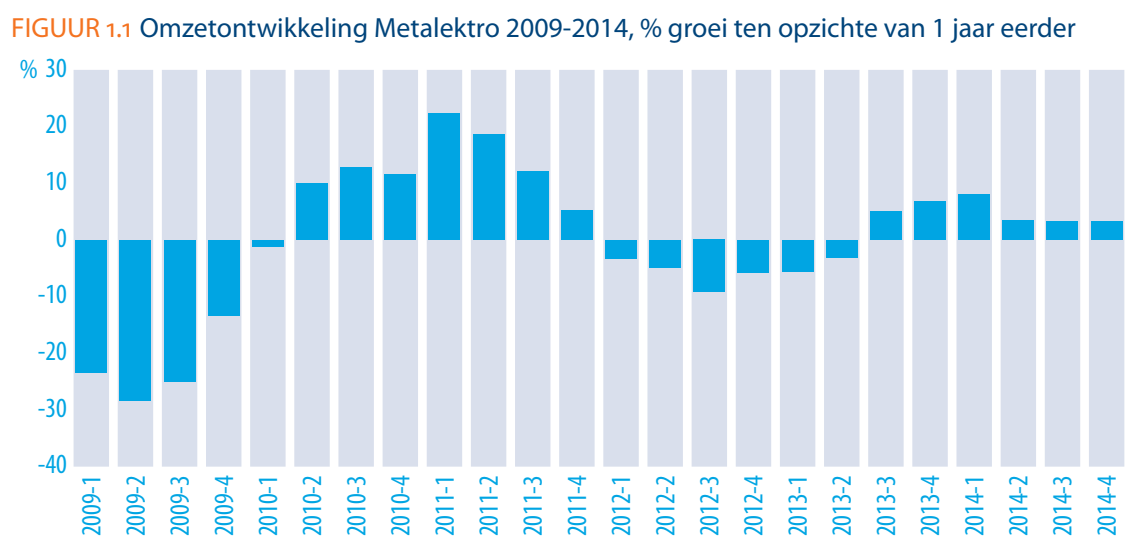

Bron: CBS, Nijverheidsstatistiek, 2009-2014

De positieve economische ontwikkelingen in de Metalektro zijn tevens zichtbaar in de conjunctuurindicatoren in Figuur 1.2. Het percentage bedrijven dat geen productiebelemmeringen kent is tussen januari 2013 en januari 2015 toegenomen. Fluctuaties daargelaten is de trend opwaarts. Voor het percentage bedrijven dat met onvoldoende vraag te maken heeft geldt een vergelijkbaar patroon. Ondanks fluctuaties, is de trend sinds 2013 dat er minder bedrijven zijn die met onvoldoende vraag te maken hebben. Het percentage bedrijven dat met belemmeringen kampt als gevolg van personeelste-

1 http://www.cbs.nl/nl-NL/menu/themas/dossiers/conjunctuur/publicaties/conjunctuurbericht/inhoud/ kwartaal/economie-groeit-in-vierde-kwartaal.htm

2 http://www.cbs.nl/nl-NL/menu/themas/internationale-handel/publicaties/artikelen/archief/2014/2014-0715-mo2.htm 
korten schommelt de laatste twee jaar rond de vijf procent, en dook daar in januari 2015 met $4,2 \%$ weer duidelijk onder.

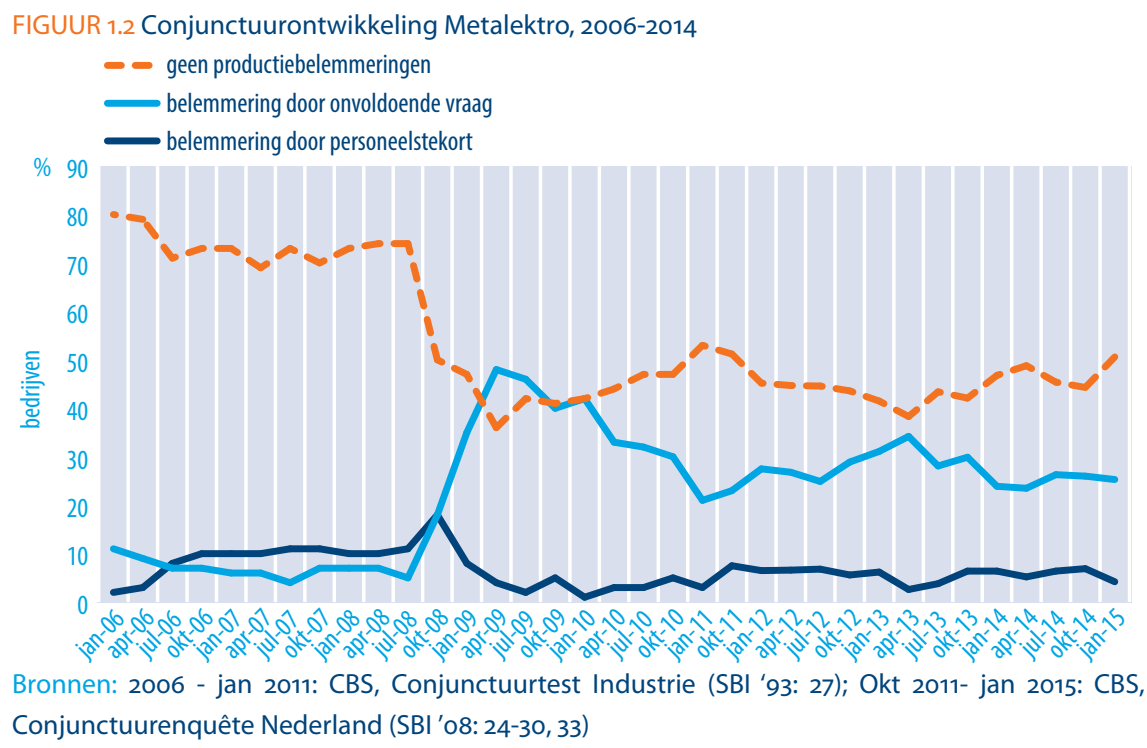

\subsection{Werkgelegenheid in de Metalektro licht gestegen}

De positieve ontwikkelingen in omzet en conjunctuurindicatoren vertalen zich ook naar positieve effecten op de werkgelegenheid in de Metalektro. Dit toont Figuur 1.3. Deze figuur toont allereerst weer de omzetgroei. Daarnaast toont de figuur een indicator die laat zien of er in het voorgaande kwartaal per saldo meer bedrijven waren die de werkgelegenheid in hun bedrijf zagen toe- of afnemen. Dit wordt in de figuur weergegeven door de balkjes. Positieve waardes van de indicator duiden er op dat er in het afgelopen kwartaal meer metalektrobedrijven waren waar de werkgelegenheid is toegenomen dan is afgenomen. Negatieve waardes van de indicator wijzen er op dat er meer bedrijven waren die moesten snijden in hun personeelsbestand dan bedrijven die in personeelsaantal groeiden. De lijn met het label 'verwachtingen komende drie maanden' laat zien of bedrijven overwegend positief of negatief zijn over de verwachte werkgelegenheidsontwikkelingen in hun bedrijf in het komende kwartaal. Duidelijk is te zien dat alle drie de indicatoren globaal dezelfde trend volgen. De gerealiseerde werkgelegenheidsontwikkelingen volgen daarbij de omzet en de verwachtingen met 1 tot hooguit 2 kwartalen vertraging.

In 2014 waren er in alle kwartalen meer bedrijven die hun werkgelegenheid zagen toenemen dan bedrijven die hun werkgelegenheid zagen afnemen. Het overwicht van bedrijven met groeiende werkgelegenheid liep zelfs op tot en met oktober 2014. Vanaf 
april 2014 toonde de rode lijn van de werkgelegenheidsverwachtingen echter een stagnerend en daarna licht dalend verloop. Dit was met een korte vertraging dan ook terug te zien in de gerealiseerde werkgelegenheidsontwikkeling over het vierde kwartaal, gemeten in januari 2015. Het overwicht van bedrijven met een groeiende werkgelegenheid was in het laatste kwartaal veel minder sterk dan in de kwartalen daarvoor.

FIGUUR 1.3 Index personeelsontwikkeling en werkgelegenheidsverwachting, 2009-2014

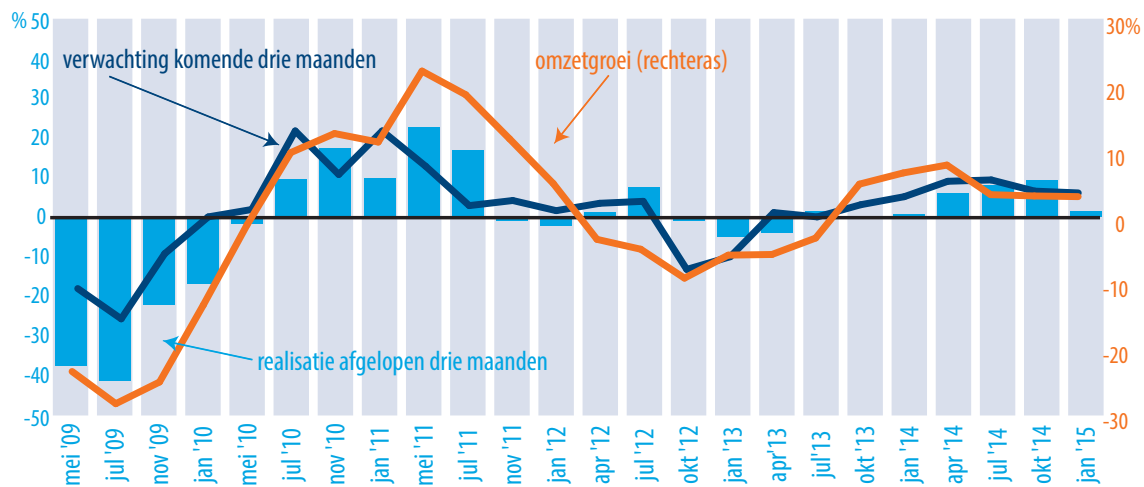

Bron: ROA, Arbeidsmarktmonitor Metalektro, 2009-2014; CBS, Nijverheidsstatistiek, 2009-2014

Ook uit cijfers van de Raad van Overleg Metalektro (ROM) blijkt dat de werkgelegenheid in de Metalektro in 2014, na een periode van daling, weer is gegroeid. Tabel 1.1 toont dat het aantal bedrijven in de sector de laatste drie jaar zo goed als gelijk is gebleven, maar dat het aantal werknemers met ruim 7.000 is gestegen in 2014 .

TABEL 1.1 Kerncijfers Metalektro 2011-2014

\begin{tabular}{|l|r|r|r|r|}
\hline & Jan. 2011 & Dec. 2012 & Dec. 2013 & Dec. 2014 \\
\hline Aantal bedrijven & 1.096 & 1.040 & 1.046 & 1.044 \\
\hline Aantal werknemers & 168.144 & 166.278 & 161.102 & 168.275 \\
\hline
\end{tabular}

Bron: Stichting Raad van Overleg Metalektro (ROM)

Uit cijfers van het CBS, die nog niet definitief voor het jaar 2014 beschikbaar zijn, blijkt dat de werkgelegenheid in de Metalektro tot en met 2013 gestaag afnam. Figuur 1.4 toont de indexcijfers voor de werkgelegenheid in de Metalektro en in Nederland totaal, met als basisjaar 2006. Duidelijk is dat de financiële crisis vanaf 2008 zowel de werkgelegenheid in Nederland als totaal als in de Metalektro getroffen heeft. Op basis van Figuur 1.3 en Tabel 1.1 hierboven verwachten wij dat de CBS cijfers voor 2014 een bescheiden stijging in werkgelegenheid gaan laten zien. 
FIGUUR 1.4 Werkgelegenheid in de Metalektro en Nederland, 2006-2013 (index met als basisjaar 2006)

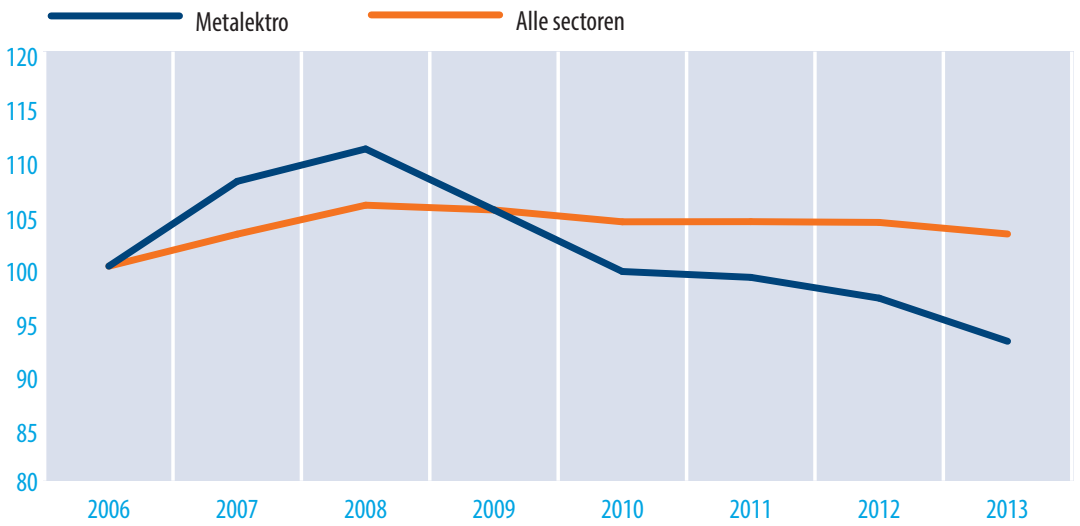

Bron: CBS, Enquête beroepsbevolking, 2006-2013

\subsection{Vergrijzing in de Metalektro}

De ontwikkeling van de leeftijdsverdeling van het personeel in de Metalektro volgt al enkele jaren dezelfde trend. Een stijgend aandeel ouderen, een stabiel aandeel jongeren en een dalend aandeel medewerkers van middelbare leeftijd. Tussen 2010 en 2011 vond de laatste sterke verandering plaats in de ontwikkeling van de leeftijdsopbouw in de Metalektro. Toen begon het percentage ouderen sneller te groeien dan voorheen. Sindsdien groeit het percentage ouderen in dit hogere tempo. Een uitgebreide analyse van de leeftijdsopbouw in de Metalektro en de daarmee gepaard gaande vraagstukken wordt in Hoofdstuk 6 besproken.

FIGUUR 1.5 Leeftijdsverdeling in de Metalektro, 2006-2013

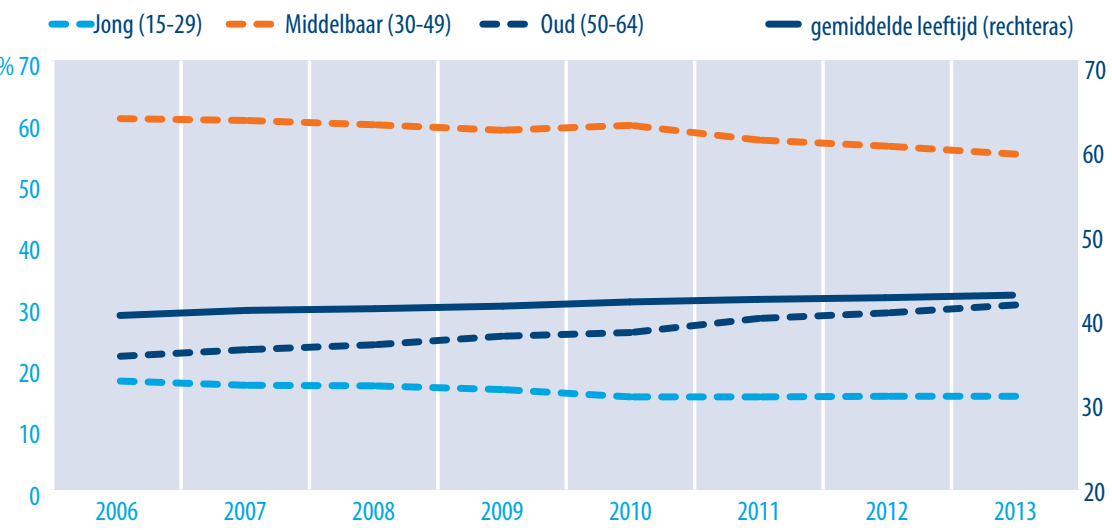

Bron: CBS, Enquête beroepsbevolking, 2006-2013 


\subsection{Gemiddelde opleidingsniveau in de Metalektro verder gestegen}

Figuur 1.6 toont het opleidingsniveau in de sector op basis van CBS data van 2002 tot en met het meest recente beschikbare jaar 2013. De stijging van het gemiddelde opleidingsniveau in de Metalektro is ook in 2013 onverminderd door gegaan. De aandelen hoger opgeleiden en middelbaar opgeleiden zijn verder gegroeid, vooral ten koste van het aandeel VMBO. Het aandeel hoger opgeleiden (HBO + WO) lag in 2013 op 28\% en het aandeel middelbaar opgeleiden (MBO) op 48\%. Vooral het aandeel hoger opgeleiden bereikte hiermee een nooit eerder behaalde omvang, terwijl het aandeel VMBO zakte tot minder dan een vijfde van het totaal. Het aandeel medewerkers met ten hoogste een basisopleiding daalt niet en schommelt al jaren rond de $5 \%$. Het totaal aandeel lager opgeleiden (BO + VMBO) was in 2013 met $24 \%$ beduidend lager dan het aandeel hoog opgeleiden (28\%). Het verschil tussen het aandeel hoger en lager opgeleiden is daarmee al opgelopen van twee procentpunt in 2012, tot vier procentpunt in 2013. De zogeheten 'upgrading' van het personeel in de Metalektro gaat daarmee onverminderd voort. In Tekstbox 1.1 worden hiervan twee praktijkvoorbeelden gegeven.

FIGUUR 1.6 Opleidingsniveau in de Metalektro 2002-2013

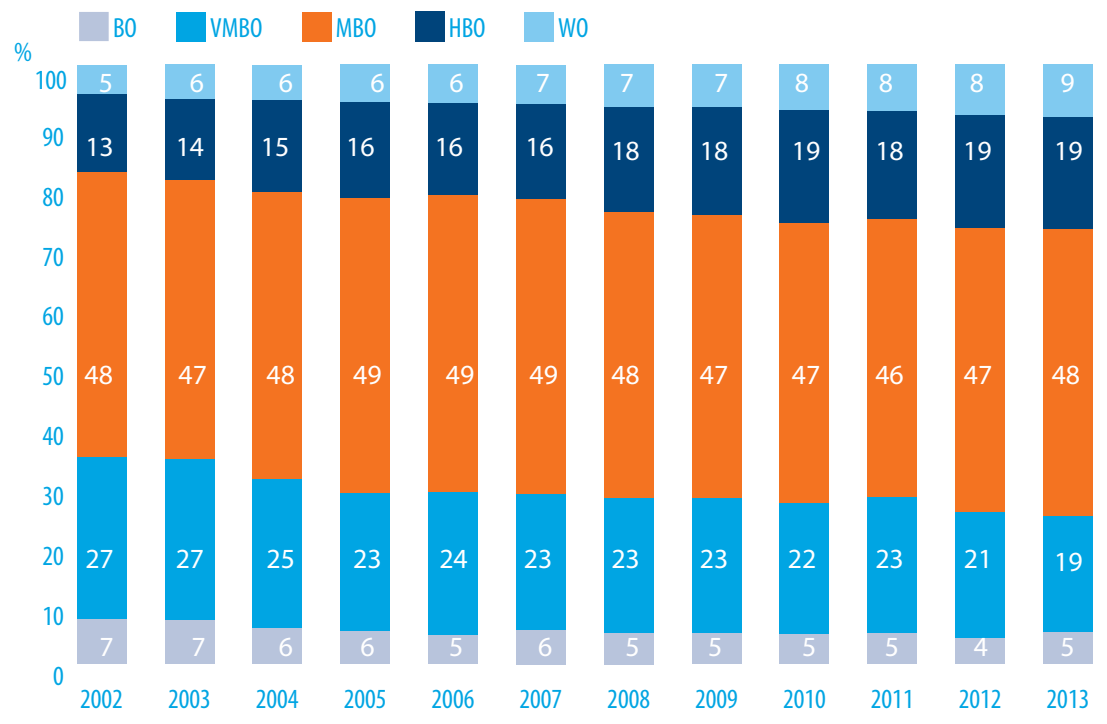

Bron: CBS, Enquête beroepsbevolking, 2002-2013 
Bij Ardagh in Deventer stijgt het gemiddeld opleidingsniveau als gevolg van twee ontwikkelingen. Ten eerste wordt volgens HR-manager Herman van der Donk in het aannamebeleid de regel gehanteerd dat onder het niveau van monteur ( $\mathrm{MBO} 2 / 3$ ) geen nieuwe werknemers meer worden aangenomen. In deze categorie, waaronder heftruckchauffeurs en inpakkers vallen, wordt geprobeerd zoveel mogelijk te mechaniseren en automatiseren of uitzendkrachten in te zetten. Ten tweede is er binnen de groep MBO-geschoolden die werkzaam zijn in het bedrijf sprake van toenemende functie-eisen. Zo geldt bij MBO niveau 2 werknemers die worden aangenomen eigenlijk dat deze meteen binnen het bedrijf verder worden opgeleid naar niveau 3.

Ook bij Miedema, producent van landbouwwerktuigen, worden de kennisvereisten voor verschillende functies steeds hoger, aldus managing director René Boeijenga. Daarnaast verdwijnen langzamerhand steeds meer functies die geen specifieke kennis vereisen. Deze functies verdwijnen onder andere door automatisering van laag geschoolde arbeid, uitbreiding van de flexibele schil en outsourcing van de productie.

\subsection{Innovaties in de Metalektro vooral gericht op verbeteringen van producten, processen en diensten}

Figuur 1.7 toont over tijd wat de verwachtingen van metalektrobedrijven zijn ten aanzien van hun innovaties in de komende drie jaar. In 2014 zijn de verwachtingen gedaald wat betreft toekomstige ontwikkeling van nieuwe (voor de markt) producten, diensten of productiemethoden. 31\% van de bedrijven verwacht de komende drie jaar producten te ontwikkelen die nieuw zijn voor de markt, $24 \%$ verwacht nieuwe productieprocessen te ontwikkelen en $7 \%$ verwacht nieuwe diensten te ontwikkelen. ${ }^{3}$ Het ontwikkelen van producten of diensten die geheel nieuw zijn voor de markt, alsmede het ontwikkelen van nieuwe productiemethoden, zijn echter geen innovaties die jaar op jaar plaats vinden. Veel producten ondergaan een productlevenscyclus die ruim langer is dan een jaar en processen worden ook niet ieder jaar geheel vernieuwd.

Om een beter genuanceerd totaalbeeld te krijgen van de innovaties en innovatieverwachtingen van metalektrobedrijven, kijken we in Figuur 1.8 naar een uitgebreider overzicht van in 2014 gerealiseerde en voor de toekomst verwachte innovaties. Hierin worden ook product- en diensteninnovaties meegenomen die wel al op de markt zijn, maar nieuw voor het bedrijf, alsook innovaties gericht op het verbeteren van bestaande producten en diensten. Daarnaast wordt ook gekeken naar innovatie door verbetering van bestaande productieprocessen en de ontwikkeling van nieuwe logistieke processen.

3 In 2014 is de vraagstelling veranderd en wordt aan de bedrijven gevraagd naar hun innovatieverwachtingen in de komende 3 jaar. Voorheen werd gevraagd naar de verwachtingen in de komende 5 jaar. Het zou kunnen zijn dat bedrijven vooral verwachtten nieuwe producten, diensten en processen te ontwikkelen vanaf 2018. Dan worden deze verwachte innovaties in de nieuwe vraagstelling niet meegenomen, terwijl deze in 2013, toen nog naar de komende 5 jaar werd gevraagd, wel mee werden genomen. Dit kan theoretisch een rol hebben gespeeld in de daling in Figuur 1.7. 
FIGUUR 1.7 Verwachte innovaties voor de komende drie jaar (\% bedrijven), 2006-2014

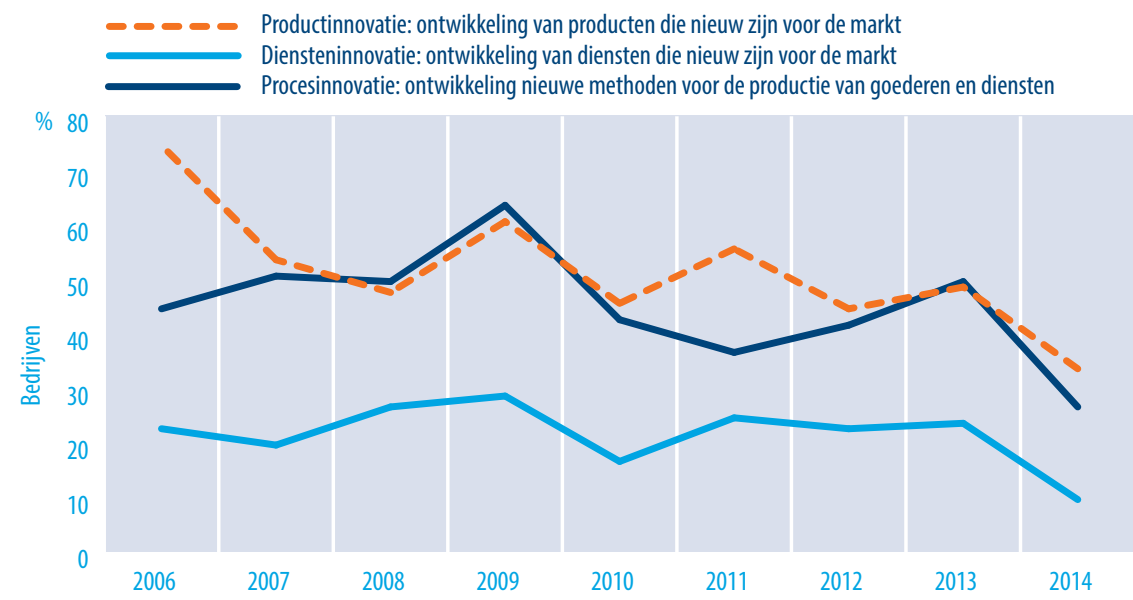

Bron: ROA, Arbeidsmarktmonitor Metalektro, 2006-2014

FIGUUR 1.8 Gerealiseerde en verwachte technologische innovaties (\% bedrijven), 2014

in 2014 in de komende 3 jaar

Geen innovatie

Productinnovatie:

Ontwikkeling van producten die nieuw zijn voor de markt

Ontwikkeling van producten die al op de markt zijn, maar

nieuw zijn voor uw bedrijf

Sterk verbeteren van producten die uw bedrijf reeds

aanbiedt

Diensteninnovatie:

Ontwikkeling van diensten die nieuw zijn voor de markt

Ontwikkeling van diensten die al op de markt zijn, maar nieuw zijn voor uw bedrijf

Sterk verbeteren van diensten die uw bedrijf reeds

aanbiedt

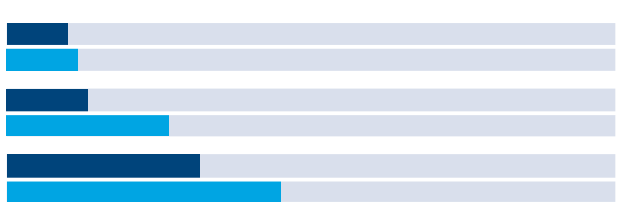

Procesinnovatie:

Ontwikkeling van nieuwe methoden voor de productie

van goederen en diensten

Sterk verbeteren van reeds gebruikte methoden voor de

productie van goederen en diensten

Ontwikkeling van nieuwe logistieke processen

Ontwikkeling van nieuwe methoden voor

ondersteunende activiteiten voor uw processen
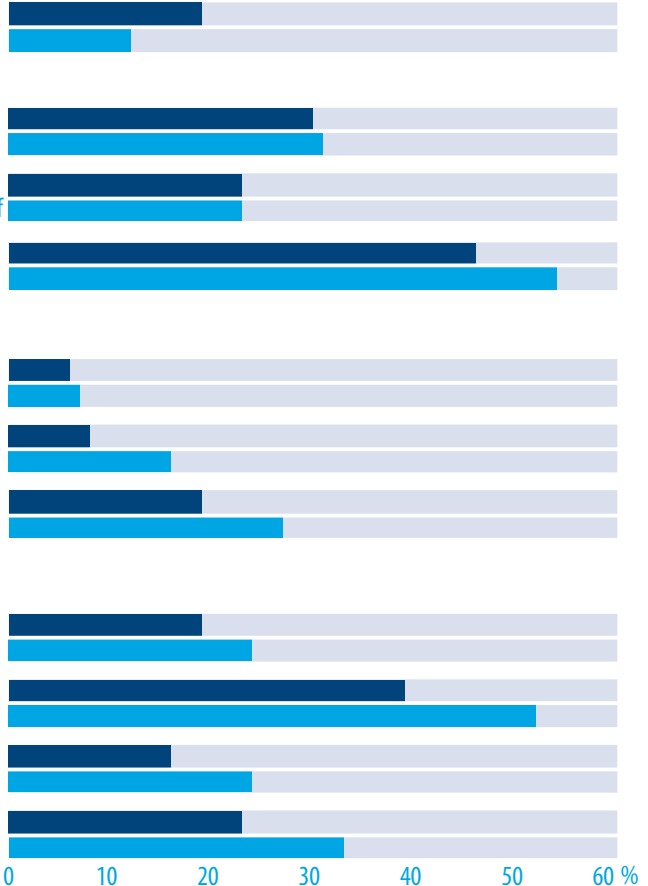

Bron: ROA, Arbeidsmarktmonitor Metalektro, 2014 
In 2014 heeft 81\% van de metalektrobedrijven één of meerdere technologische innovaties doorgevoerd. Hierin zijn wel regionale verschillen. Het percentage bedrijven dat technologische ontwikkelingen heeft doorgevoerd is iets lager in het westen (71\%) dan in het zuiden (90\%). Evenals de afgelopen jaren lag de nadruk ook in 2014 op innovaties gericht op het sterk verbeteren van bestaande producten (46\%) en methoden (39\%). Ook wordt voor de komende drie jaar juist een toename verwacht in innovaties gericht op het verbeteren van bestaande producten, processen en diensten. Daarnaast is het percentage bedrijven dat in de toekomst helemaal niet verwacht te innoveren (12\%) lager dan het in 2014 was (19\%). Metalektrobedrijven zijn dus wel degelijk in grote meerderheid gericht op innovatie, maar de focus ligt op dit moment meer op verbetering van het bestaande, dan op compleet nieuwe ontwikkelingen. 



\section{2 \\ ARBEIDSMARKTONTWIKKELINGEN METALEKTRO 2014}

Per saldo was er over 2014 als geheel een overschot van bedrijven met een instroom van nieuwe medewerkers, maar dit komt volledig op conto van de eerste helft van het jaar toen het percentage bedrijven met instroom het percentage bedrijven met uitstroom ruimschoots overtrof. In de tweede helft van het jaar was het percentage bedrijven met instroom van nieuwe medewerkers vrijwel gelijk aan het percentage bedrijven met uitstroom. Het grootste overwicht van bedrijven met instroom over bedrijven met uitstroom vinden we over heel 2014 bezien bij de engineering en R\&D functies, waar relatief gezien de sterkste netto instroom plaats vond. In de eerste helft van 2014 groeide ook de flexibele schil sterk, vooral door een toename van het aantal medewerkers met een tijdelijk contract. In de tweede helft van het jaar kromp de flexibele schil echter weer door een afname van het aandeel tijdelijke contracten. Signalen van bedrijven uit de sector wijzen er op dat een deel van de tijdelijke contracten in vaste contracten is omgezet als gevolg van de tot dan toe aanhoudende positieve economische ontwikkelingen. Dit past in het beeld van de licht groeiende werkgelegenheid in de sector dat in Hoofdstuk 1 werd getoond. 


\subsection{Per saldo meer bedrijven met instroom dan bedrijven met uitstroom van personeel}

Het percentage bedrijven met instroom van nieuw personeel lag in de eerste helft van 2014 op 72\%, terwijl het percentage bedrijven met uitstroom op 59\% lag. Een ruim overschot dus van bedrijven met instroom over bedrijven met uitstroom. In de tweede helft van 2014 lag het percentage bedrijven met instroom iets lager dan in de eerste helft van het jaar, namelijk op 68\%. Het percentage bedrijven met uitstroom lag in de tweede helft van het jaar flink hoger dan in de eerste helft en kwam op 69\%, vrijwel gelijk aan het percentage bedrijven met instroom. Per saldo was er over 2014 als geheel wel een overschot van bedrijven met instroom, maar dit komt volledig op conto van de eerste helft van het jaar. In Figuren 2.1 en 2.2 gaan we nader in op het percentage bedrijven met instroom en uitstroom.

FIGUUR 2.1 Instroom naar functiecategorie (\% bedrijven), 2014

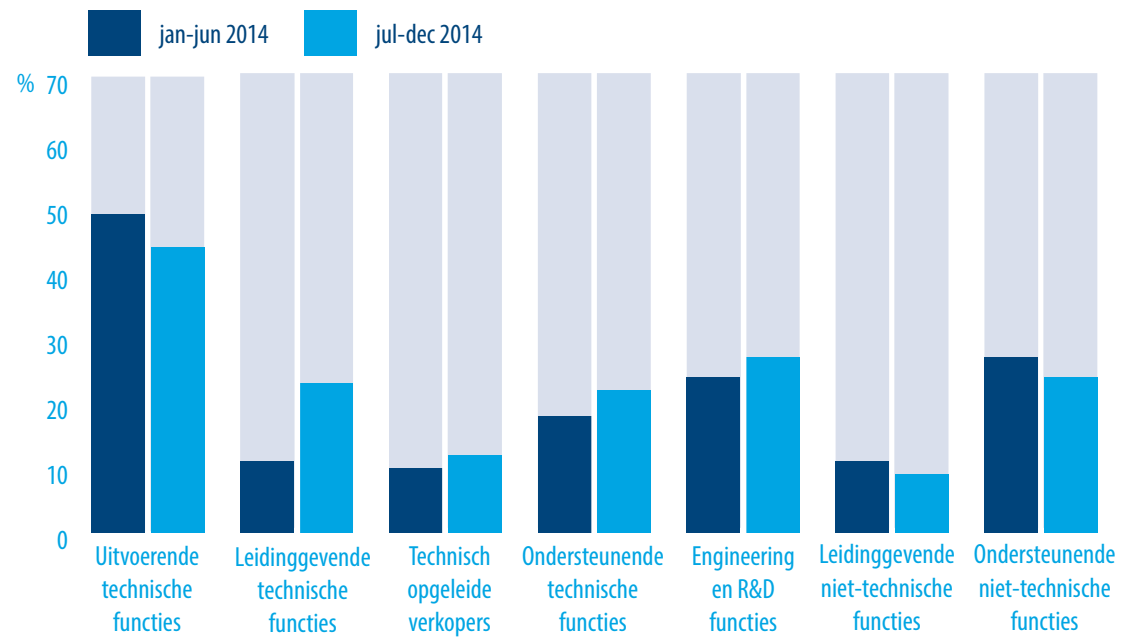

Bron: ROA, Arbeidsmarktmonitor Metalektro, 2014

Figuur 2.1 toont de percentages bedrijven met instroom van nieuwe medewerkers in 2014 naar functiecategorie en jaarhelft. Van alle functiecategorieën werden uitvoerende technici door de meeste bedrijven aangetrokken. Bijna de helft van de bedrijven trok uitvoerende technici aan in de eerste helft van 2014 en in de tweede helft van het jaar betrof dit 44\%. Ook engineering en R\&D personeel en ondersteunend niet-technisch personeel werd in beide jaarhelften door ongeveer een kwart van de bedrijven aangetrokken. Verder valt op dat het percentage bedrijven dat leidinggevende technici aantrok ruim verdubbelde in de tweede helft van het jaar, een ontwikkeling die we ook in 2013 zagen. Tot slot is gebleken dat grote bedrijven significant vaker nieuwe mede- 
werkers aantrokken dan MKB bedrijven. Dit geldt voor vrijwel alle functiecategorieën in beide jaarhelften. ${ }^{4}$

Figuur 2.2 toont het percentage bedrijven met personeelsuitstroom in de eerste en tweede helft van 2014 voor de verschillende functiecategorieën. Bij de meeste functiecategorieën waren er in de tweede helft van het jaar meer bedrijven met uitstroom dan in de eerste helft van het jaar. Alleen bij technisch opgeleide verkopers en ondersteunende technische functies was dit omgekeerd. Het hoogste percentage bedrijven met uitstroom is te zien bij de functiegroep die ook het grootst is in de sector, de uitvoerende technische functies. $40 \%$ van de bedrijven had met uitstroom van uitvoerende technici te maken in de eerste helft van het jaar en dit was ruim 50\% in de tweede helft van het jaar. Onder grote bedrijven was significant vaker sprake van uitstroom van personeel dan in het MKB, ongeacht de functiecategorie.

FIGUUR 2.2 Uitstroom naar functiecategorie (\% bedrijven), 2014

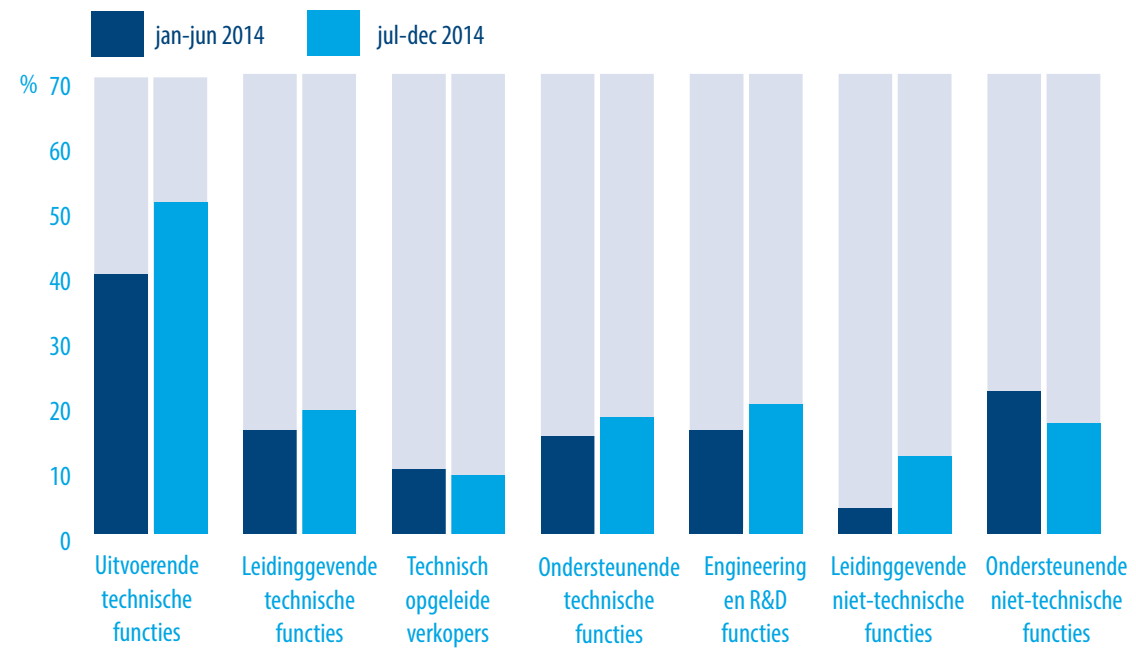

Bron: ROA, Arbeidsmarktmonitor Metalektro, 2014

Per saldo blijkt uit de Figuren 2.1 en 2.2 dat er in 2014 nog altijd meer bedrijven waren met instroom dan bedrijven met uitstroom voor alle functiecategorieën behalve de leidinggevende technische functies. Voor deze laatstgenoemde functiecategorie is het aantal bedrijven met instroom en uitstroom in balans. Voor de overige functiecategorieën was er in 2014 dus een overwicht van bedrijven met instroom. Het grootste overwicht vinden we bij de engineering en R\&D functies, op de voet gevolgd door de ondersteunende niet-technische functies. Ook voor ondersteunende technische functies was het overwicht van bedrijven met instroom duidelijk zichtbaar. Voor de leidinggevende niet-technische functies, technisch opgeleide verkopers en uitvoerende technici was er

4 Met uitzondering van leidinggevende niet-technische functies in eerste helft van het jaar en technisch opgeleide verkopers in de tweede helft van het jaar. 
weliswaar ook een overwicht van bedrijven met instroom over bedrijven met uitstroom, maar dit overwicht was klein.

\section{Uitvoerende technische functies nader bekeken: trendbreuk in het percentage bedrijven met uitstroom in 2014?}

In Figuur 2.3 gaan we nader in op het percentage bedrijven met instroom en uitstroom van uitvoerende technici, wat veruit de grootste functiecategorie in de Metalektro is. Van 2011 tot en met de eerste helft van 2014 was er continue sprake van een overwicht aan bedrijven met instroom van uitvoerende technici. In de tweede helft van 2014 is hier voor het eerst sinds 2010 dus weer verandering in gekomen en was het percentage bedrijven met uitstroom van uitvoerende technici groter dan het percentage bedrijven met instroom hiervan. Het percentage bedrijven met uitstroom van uitvoerende technici is in de tweede helft van het jaar met ruim tien procentpunten gestegen, van $40 \%$ tot $51 \%$. Het percentage bedrijven met instroom van uitvoerende technici betrof in de tweede helft van het jaar 44\%. Dankzij een overwicht van bedrijven met instroom in de eerste helft van het jaar is er over 2014 als geheel beschouwd nog altijd sprake van een zeer klein overwicht van bedrijven met instroom. Het zal in 2015 blijken of deze stijging van het percentage bedrijven met uitstroom van korte duur was of dat een nieuwe trend heeft ingezet.

\section{FIGUUR 2.3 In- c.q. uitstroom van uitvoerend technisch personeel (\% bedrijven), 2006-2014}

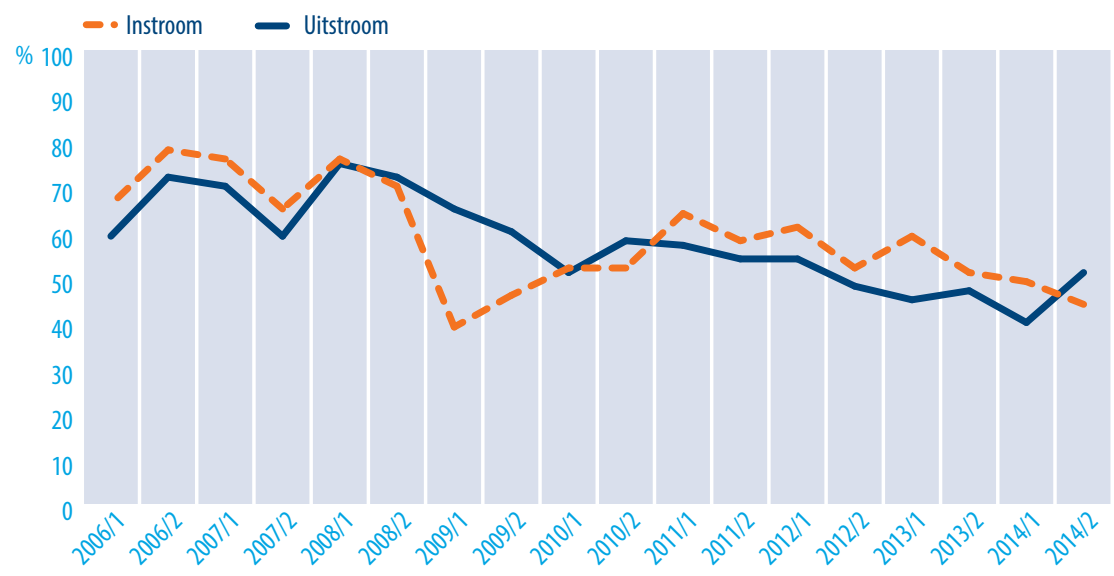

Bron: ROA, Arbeidsmarktmonitor Metalektro, 2006-2014

\subsection{Eventuele krimp in werkgelegenheid voornamelijk opgevangen met flexibele schil}

Figuur 2.4 toont per functiecategorie hoeveel procent van de metalektrobedrijven op de peilmomenten eind 2013 en eind 2014 te maken had met krimpende werkgelegenheid. 
Voorop staat dat een meerderheid van de bedrijven op beide peilmomenten in geen enkele functiecategorie te maken had met krimpende werkgelegenheid. Maximaal tien procent van de bedrijven had eind 2014 te maken met krimp in engineering en R\&D functies, ondersteunende technische functies, leidinggevende technische functies of technisch opgeleide verkopers. $10 \%$ tot $18 \%$ van de bedrijven had te maken met krimpende werkgelegenheid ten aanzien van uitvoerende technici, ondersteunende niettechnische functies of leidinggevende niet-technische functies. De grootste verschuiving ten opzicht van het peilmoment in 2013 is de stijging in het percentage bedrijven dat krimp ziet in engineering en $R \& D$ functies, hoewel dit met $10 \%$ nog altijd weinig is.

FIGUUR 2.4 Krimpende werkgelegenheid naar functiecategorie (\% bedrijven), 2013-2014

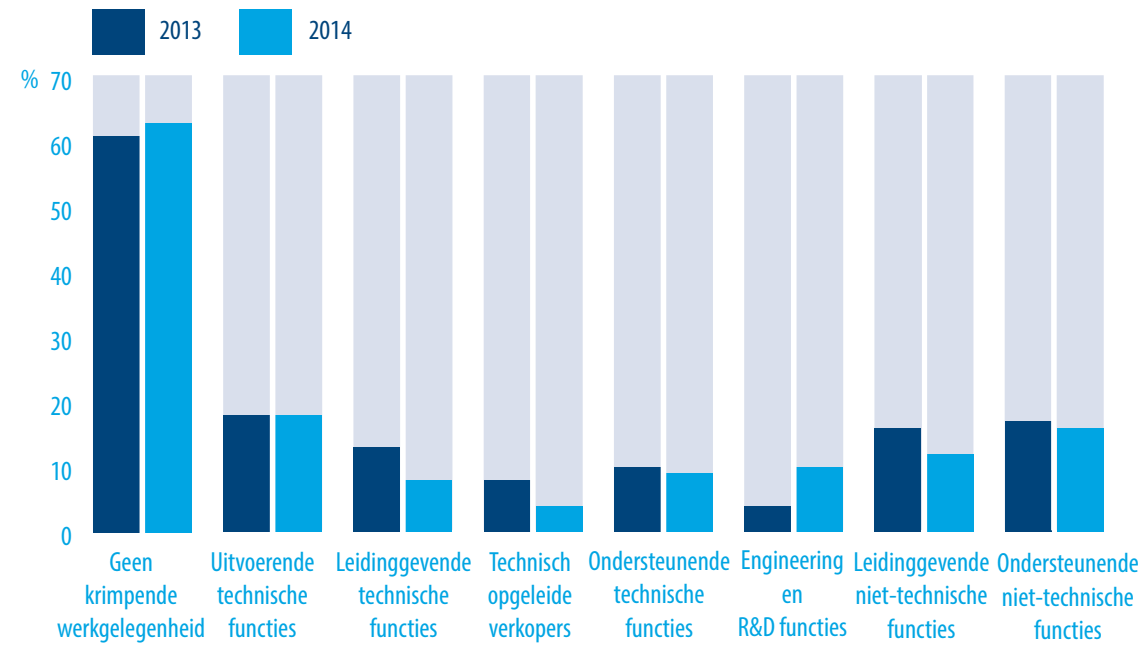

Bron: ROA, Arbeidsmarktmonitor Metalektro, 2013-2014

Hoe de metalektrobedrijven die met krimp te maken hebben hiermee om gaan wordt weergegeven in Tabel 2.1, waarin we voor de afgelopen drie jaar de top vijf tonen van meest voor komende gevolgen van krimp in de werkgelegenheid. Het niet verlengen van tijdelijke contracten was in 2014 het meest voor komende gevolg van krimp in werkgelegenheid. Ook in 2013 stond dit bovenaan en in 2012 stond dit op de tweede plaats in de top vijf. Dit onderstreept het belang voor de metalektrobedrijven van het hebben van een flexibele schil. Tekstbox 2.1 illustreert dat de flexibele schil diverse rollen kan vervullen voor bedrijven, waaronder het opvangen van (seizoensgebonden) krimp en fluctuaties in bedrijfsdrukte, maar ook werving en selectie. Het afkondigen van een vacaturestop werd in 2014 ook door een aanzienlijk deel (40\%) van de bedrijven met krimp in werkgelegenheid toegepast. In 2012 stond de vacaturestop zelfs op de eerste plaats, maar in 2013 stond deze net buiten de top vijf, op plaats zes. Op de derde plaats staat in 2014 het niet vervangen van werknemers die met pensioen gaan. Bijna een derde van de bedrijven met krimp in werkgelegenheid paste dit toe in 2014. Ook in 2012 en 2013 stond dit in de top drie. Ruim een kwart van de bedrijven met krimp heeft in 2014 
werknemers overgeplaatst binnen het bedrijf en bij ruim een vijfde van de bedrijven leidde de krimp in werkgelegenheid tot het vertrek van werknemers op eigen initiatief. Gedwongen ontslagen staan, in tegenstelling tot in eerdere jaren, in 2014 niet in de top vijf. Slechts 15\% van de metalektrobedrijven zagen zich in 2014 hiertoe genoodzaakt als gevolg van krimpende werkgelegenheid.

TABEL 2.1 Top vijf gevolgen krimpende werkgelegenheid van technisch personeel, 2012-2014

\begin{tabular}{|l|l|l|l|}
\hline Top 5 & 2012 & 2013 & 2014 \\
\hline 1 & Vacaturestop (51\%) & $\begin{array}{l}\text { Tijdelijke contracten niet } \\
\text { verlengen (43\%) }\end{array}$ & Tijdelijke contracten niet verlengen (43\%) \\
\hline 2 & $\begin{array}{l}\text { Tijdelijke contracten niet } \\
\text { verlengen (41\%) }\end{array}$ & $\begin{array}{l}\text { Niet vervangen werknemers } \\
\text { die met pensioen gaan (43\%) }\end{array}$ & \begin{tabular}{l} 
Vacaturestop (40\%) \\
\hline 3
\end{tabular} \\
\hline $\begin{array}{l}\text { Niet vervangen werknemers } \\
\text { die met pensioen gaan (32\%) }\end{array}$ & $\begin{array}{l}\text { Overplaatsing van } \\
\text { werknemers binnen het } \\
\text { bedrijf (32\%) }\end{array}$ & $\begin{array}{l}\text { Niet vervangen werknemers die met pensioen } \\
\text { gaan (31\%) }\end{array}$ \\
\hline 4 & $\begin{array}{l}\text { Werknemers stimuleren } \\
\text { eerder met pensioen te gaan } \\
\text { (27\%) }\end{array}$ & $\begin{array}{l}\text { Werknemers vertrekken op } \\
\text { eigen initiatief (31\%) }\end{array}$ & $\begin{array}{l}\text { Overplaatsing van werknemers binnen het bedrijf } \\
\text { (26\%) }\end{array}$ \\
\hline 5 & Gedwongen ontslagen (22\%) & Gedwongen ontslagen (27\%) & Werknemers vertrekken op eigen initiatief (22\%) \\
\hline
\end{tabular}

Bron: ROA, Arbeidsmarktmonitor Metalektro, 2012-2014

TEKSTBOX 2.1 De flexibele schil om schommelingen op te vangen en als wervingskanaal

Miedema, producent van landbouwwerktuigen, is volgens managing director René Boeijenga een erg cyclisch bedrijf. Grote fluctuaties in het personeelsbestand en de productie doen zich vooral binnen het jaar voor. Zo is de periode oktober-december een erg rustige periode waarbij het bedrijf ruim beneden zijn capaciteit draait, terwijl het bedrijf rond augustus overuren draait. Naast deze seizoenfluctuaties, zijn er ook fluctuaties zichtbaar over de jaren. De grote seizoensgebondenheid vraagt om een omvangrijke flexibele schil, aldus Boeijenga. Deze flexibele schil is in oktober nagenoeg $0 \%$, maar in maanden als augustus al snel $20 \%$ tot $40 \%$ van het totale personeelsbestand bij Miedema.

Bij Royal Smit Transformers B.V. in Nijmegen maakt de flexibele schil ook een substantieel deel uit van het totale personeelsbestand, namelijk zo'n 20-25\%. De flexibele schil heeft niet alleen tot doel om eventuele schommelingen in de productie op te vangen, maar wordt ook gebruikt als wervingskanaal. Smit steekt samen met haar 'In-House' uitzend- en wervings- en selectiebureau veel energie in het werven van uitzendkrachten, aldus Mèlanie Jansen-van Lendt, senior personeelsfunctionaris bij Smit. Het resultaat is dat veel uitzendkrachten in de praktijk goed matchen met Smit en dat uiteindelijk zo'n $70 \%$ van hen doorstroomt naar een contract bij Smit zelf. 


\subsection{Daling in omvang flexibele schil na bereiken van record in juli 2014}

De flexibele schil in de Metalektro blijft de omzetontwikkeling in de sector nauwgezet volgen. Figuur 2.5 geeft dit weer. Sinds medio 2012 is de dalende trend in de omzetgroei doorbroken en sinds de tweede helft van 2013 is de omzetgroei positief geweest. In het eerste kwartaal van 2014 bereikte de omzetgroei een voorlopige nieuwe piek van 8\%, waarna de omzetgroei wat zakte en drie kwartalen op rij net boven de $3 \% \mathrm{kwam}$. De omzet dicht volgend, bereikte de flexibele schil in juli 2014 een voorlopig record; 43\% van de werknemers in de Metalektro had toen een flexibel contract. Het grootste deel hiervan waren tijdelijke contracten, maar ook het aandeel ingeleende medewerkers, af te lezen aan de hoogte van de bovenste band, stond in juli 2014 op een hoogte welke sinds januari 2011 niet meer bereikt was. De gedaalde maar nog altijd positieve omzetgroei in het tweede tot en met vierde kwartaal van 2014 had ook zijn uitwerking op de flexibele schil, die licht begon te krimpen en in januari 2015 op 37\% stond. Hieraan kunnen we een positieve en een negatieve interpretatie geven.

FIGUUR 2.5 Omvang flexibele schil en omzetgroei in de Metalektro, 2010-2014

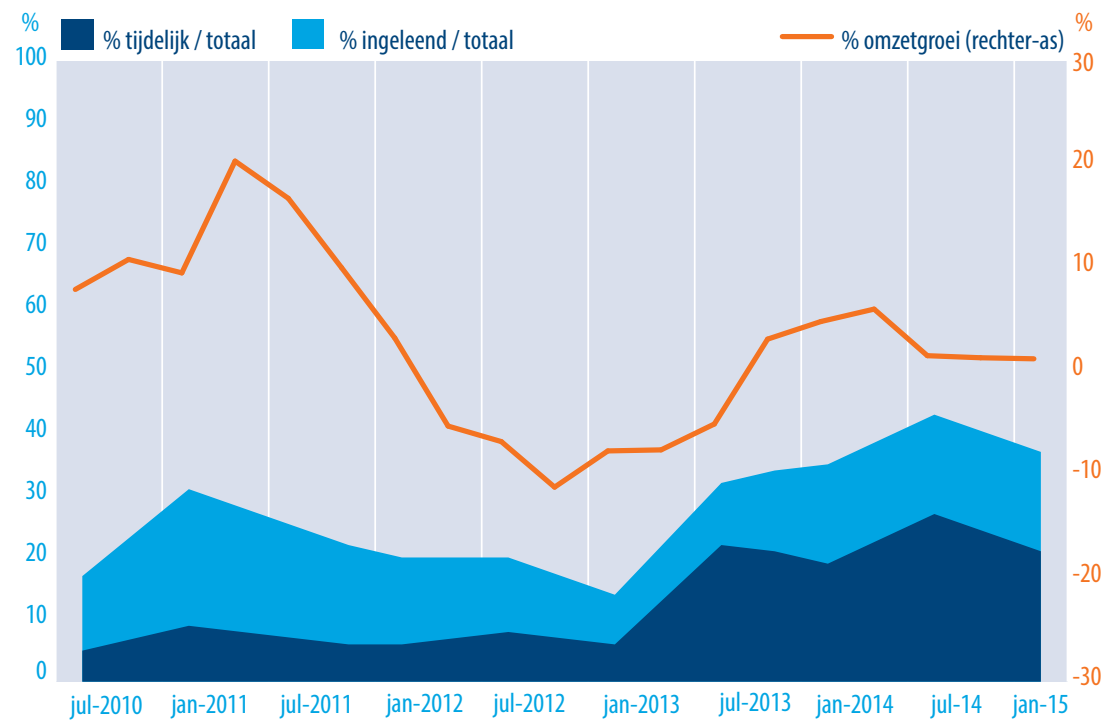

Bron: ROA, Arbeidsmarktmonitor Metalektro, 2010-2014

Als eerste de positieve interpretatie: Vooral het aandeel werknemers op tijdelijke contracten, welke in de eerste helft van 2014 nog zo toenam, daalde in de tweede helft van het jaar. Het is niet ondenkbaar dat, gezien de tot dan toe aanhoudend positieve omzetgroei, bedrijven een deel van de tijdelijk aangestelde werknemers een vast contract hebben aangeboden, wat het percentage tijdelijke contracten heeft doen afnemen. De negatieve interpretatie zou zijn dat de daling in de omzetgroei van $8 \%$ naar een $3 \%$ aanleiding kan zijn geweest om de verwachtingen al weer wat te temperen en 
daarom al een deel van de sterk gegroeide tijdelijke contracten juist niet te verlengen. Gezien het feit dat de totale werkgelegenheid in de Metalektro licht is gegroeid in 2014 (zie Tabel 1.1), zou men geneigd kunnen zijn de positieve interpretatie te verkiezen. Signalen van bedrijven uit de sector wijzen ook in deze richting: door de (bedrijfs) economische ontwikkelingen tot en met de tweede helft van 2014 is het vertrouwen dermate gegroeid dat men is overgegaan tot het omzetten van een deel van de tijdelijke contracten in vaste contracten. Dit is mede ingegeven door de wens om zich in positieve zin te onderscheiden van andere werkgevers, om op die manier getalenteerde werknemers aan zich te binden en makkelijker aan te kunnen trekken.

\subsection{Kleine krimp in de flexibele schil in 2e helft 2014 betrof vooral uitvoerende en ondersteunende technici}

Figuur 2.6 toont de ontwikkeling van de flexibele schil voor de afzonderlijke technische functiecategorieën. Deze ontwikkeling verschilde in 2014 sterk per functiecategorie. De zeer recente daling in de omvang van de totale flexibele schil in de Metalektro (zie Figuur 2.5) wordt met name veroorzaakt door de ontwikkeling van het aandeel flexibele krachten in zowel uitvoerende als ondersteunende technische functies. In de eerste helft van 2014 steeg voor deze functiecategorieën het aandeel van de flexibele schil nog en bracht daarmee de omvang van de gehele flexibele schil in de Metalektro op recordhoogte in juli 2014. Daarna daalde in deze functiecategorieën het aandeel flexibele krachten relatief sterk. Toch is het aandeel flexibele krachten in uitvoerende technische functies nog altijd ruim 50\% van het totaal aantal werkenden in die functies. Bij de leidinggevende technische functies en technisch opgeleide verkopers zien we in 2014 een beweging tegengesteld aan die bij de uitvoerende en ondersteunende technici. Het aandeel flexibele krachten in leidinggevende technische functies en technisch opgeleide verkopers daalde in de eerste helft van 2014 licht en steeg juist relatief sterk tussen juli 2014 en januari 2015. Wat betreft engineering en R\&D functies geldt dat de flexibele schil onverminderd groter is geworden de afgelopen twee jaar. 
FIGUUR 2.6 Ontwikkeling flexibele schil naar technische functiecategorie (\% medewerkers), 20132014

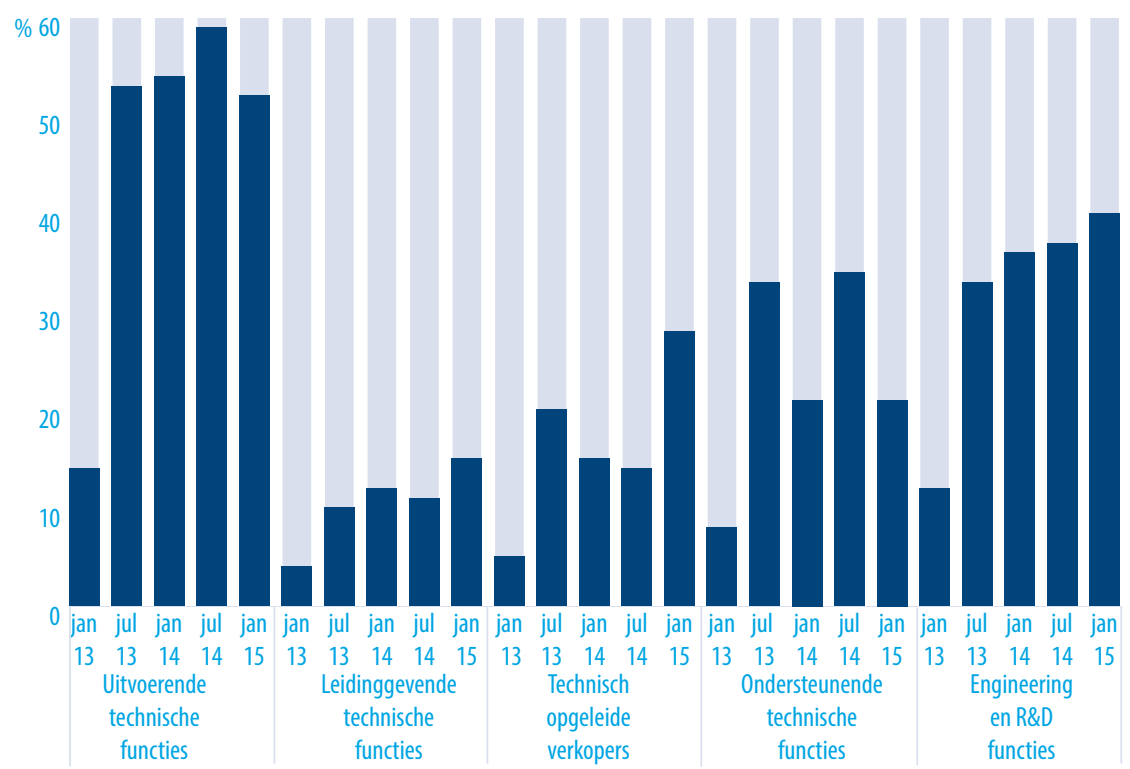

Bron: ROA, Arbeidsmarktmonitor Metalektro, 2013-2014

Noot: Het overige, niet in de figuur weergegeven, deel van de dienstverbanden in elke functiecategorie bestaat uit medewerkers in vaste loondienst. Het percentage medewerkers met een vast contract plus het percentage met een flexibel contract tellen samen op tot $100 \%$.

\section{TEKSTBOX 2.2 Wetgeving omtrent de flexibele schil wordt soms als beperkend ervaren}

Ondanks dat de flexibele schil bij Miedema door het jaar heen kan schommelen tussen de bijna $0 \%$ en 40\% (zie Tekstbox 2.1), zou Miedema volgens managing director René Boeijenga de flexibele schil nog verder willen uitbreiden. De mogelijkheden hiertoe worden echter beperkt door wet- en regelgeving: "het ontslagrecht is in Nederland te rigide om iets aan te durven" volgens Boeijenga. 0ok om deze reden spelen automatisering en verplaatsing van werk naar het buitenland een steeds grotere rol.

Ook directeur Hero Werkman, van Werkman Horseshoes, geeft aan dat ze de flexibele schil wel zouden willen uitbreiden, maar dat dit erg lastig is gezien de wet- en regelgeving. Plannen om de flexibele schil uit te breiden lopen daardoor al snel vast volgens de heer Werkman. Het alternatief dat vervolgens gekozen wordt is, net als bij Miedema, vaak het automatiseren van het betreffende werk, wat volgens de heer Werkman helaas ten koste van werkgelegenheid gaat, maar toch nodig is. 



\section{3 \\ VACATURES EN WERVING}

Vacatures ontstonden in 2014 vooral door de toename van het werk. Hoewel vacatures met name in de laatste maanden van 2014 gemiddeld iets langer open blijken te staan, is er een lichte afname van de wervingsproblemen die de bedrijven ervaren. De wervingsproblemen die er zijn, concentreren zich met name op de uitvoerende technische functies en de engineering en R\&D functies en worden vooral toegeschreven aan het feit dat de sollicitanten over onvoldoende competenties beschikken. Om met moeilijk vervulbare vacatures om te gaan, zetten metalektrobedrijven hun huidige personeel vaak flexibel in of laten ze hun medewerkers overuren draaien. Mede als gevolg hiervan geven bedrijven aan dat wervingsproblemen veelal leiden tot een toename van de werkdruk. 


\subsection{Percentage bedrijven met vacatures relatief stabiel in 2014}

Het percentage bedrijven met vacatures bleef in 2014 voor de meeste functiecategorieën stabiel (Figuur 3.1). Ongeveer een derde van de metalektrobedrijven had in 2014 vacatures voor uitvoerende technici. Voor de andere functiecategorieën was het aandeel bedrijven met vacatures lager. De enige (kleine) verschuivingen zijn te zien in de lichte daling in het aandeel bedrijven met vacatures voor engineering en R\&D personeel en ondersteunende technici, en de lichte stijging in het aandeel bedrijven met vacatures voor technisch opgeleide verkopers.

FIGUUR 3.1 Percentage bedrijven met vacatures, naar functiecategorie, 2011-2014

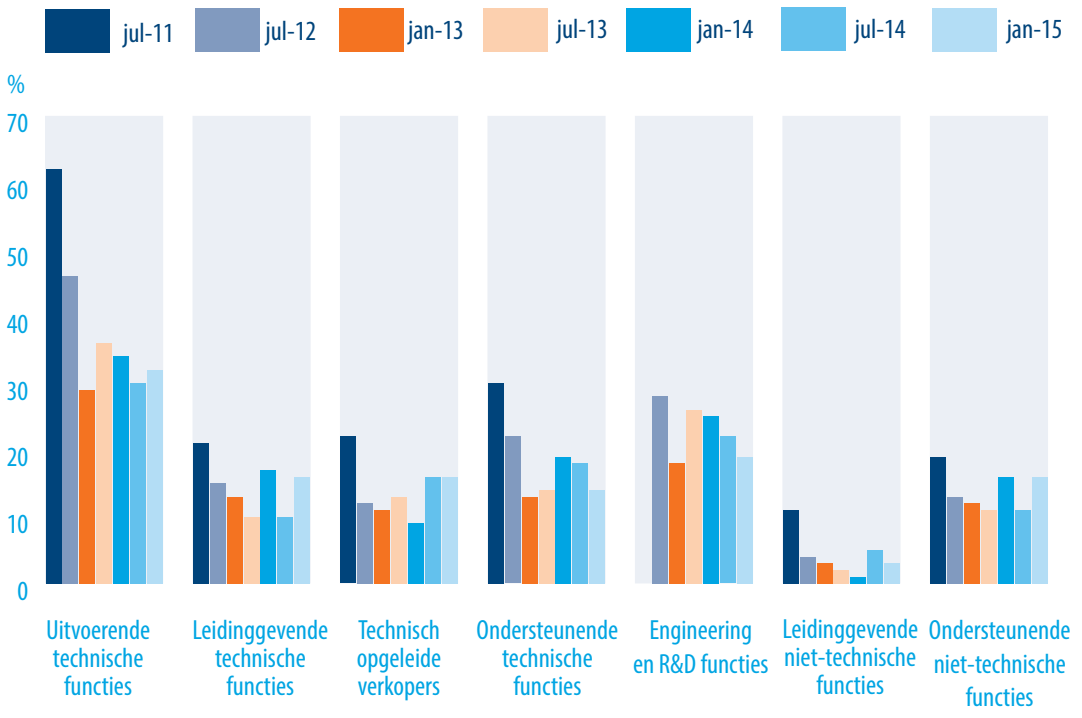

Bron: ROA, Arbeidsmarktmonitor Metalektro, 2011-2014

Noot: Voor de functiecategorie engineering en R\&D personeel zijn geen cijfers beschikbaar van voor 2012

In Figuur 3.2 is weergeven hoe lang deze vacatures open stonden. Er waren in 2014 geen bedrijven die aangaven dat vacatures gemiddeld langer dan een jaar open stonden. Het is nog zelden vertoond dat er vier kwartalen op rij geen bedrijven in het arbeidsmarktmonitor panel waren met dergelijke lang openstaande vacatures. In het algemeen was 2014 dus niet een jaar waarin bedrijven geconfronteerd werden met grote problemen bij het invullen van hun vacatures. Toch zijn er enkele lichte verschuivingen tussen de eerste en tweede helft van het jaar, en dan met name in het laatste kwartaal van 2014. Het aandeel vacatures dat tussen de 6 en 12 maanden open stond daalde in de eerste helft van 2014, maar nam in de tweede helft van het jaar weer toe. Het tegenovergestelde geldt voor het aandeel vacatures dat korter dan 6 maanden open stond. Dit aandeel nam toe in de eerste helft van het jaar om vervolgens weer licht te dalen in de tweede 
helft van het jaar. Bedrijven hadden in de eerste helft van 2014 dus iets minder tijd nodig voor het invullen van hun vacatures dan in de tweede helft van 2014. Met name in het vierde kwartaal lijken de gevolgen van de licht aantrekkende arbeidsmarkt zichtbaar te worden in vacatureduur. Opvallend is vooral de afname van het aandeel vacante posities dat binnen 1 maand kon worden ingevuld. Dit daalde scherp in het vierde kwartaal. Dit ging gepaard met een toename van de aandelen vacatures dat tussen de 1 en 2 en tussen de 6 en 12 maanden open stond.

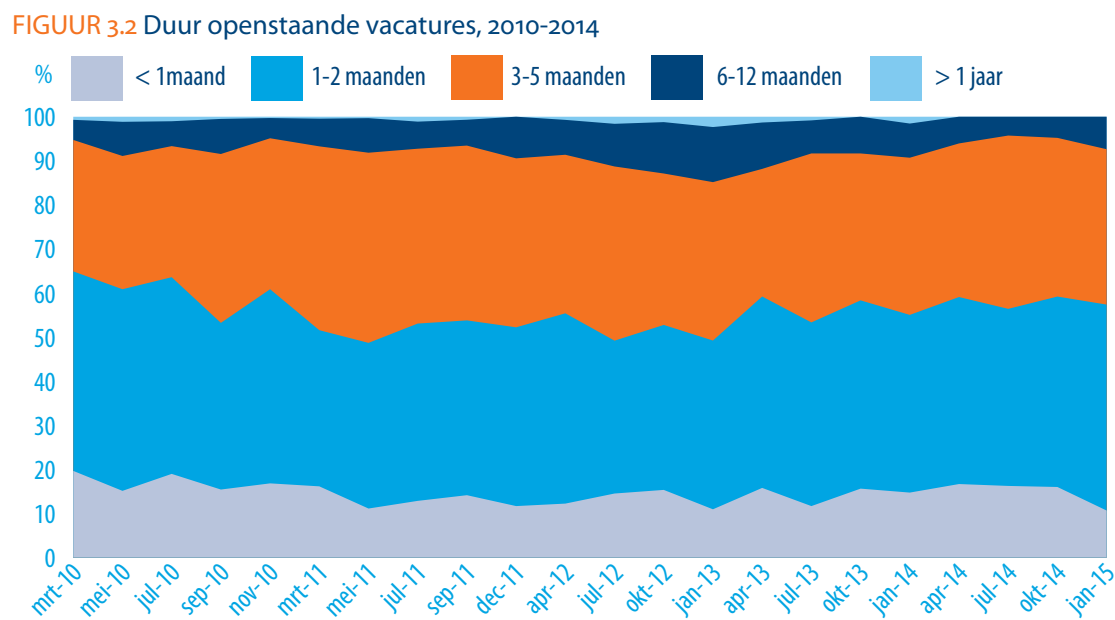

Bron: ROA, Arbeidsmarktmonitor Metalektro, 2010-2014

\subsection{Toename van hoeveelheid werk belangrijkste ontstaansreden vacatures}

Naast het aantal bedrijven met openstaande vacatures en de duur dat deze vacatures open staan kan er ook worden gekeken naar de ontstaansredenen van vacatures. Als vacatures vooral ontstaan als gevolg van een toename in de hoeveelheid werk dan wijst dit op een verbetering in de onderliggende (bedrijfs)economische situatie; als de vacatures vooral ontstaan doordat bestaand personeel met (pre)pensioen gaat, dan betreft het enkel de vervanging van vertrekkend personeel, zonder dat hier een (bedrijfs) economische verbetering aan ten grondslag ligt.

In Figuur 3.3 zijn de ontstaansredenen van vacatures voor technici weergeven. Een toename van de hoeveelheid werk is de meest gekozen ontstaansreden voor nieuwe vacatures. Deze optie is bij de meest recente meting van januari 2015 door $64 \%$ van de bedrijven gekozen en is daarnaast de ontstaansreden die het sterkst is gestegen. In de tweede helft van 2014 nam deze ontstaansreden toe met 9 procentpunt ten opzicht van de eerste helft van het jaar. Dit wijst op een verbeterde onderliggende (bedrijfs)economische situatie, wat wordt onderstreept door het feit dat deze ontstaansreden de enige is die in de afgelopen vier metingen consequent is toegenomen. Een andere ontstaans- 
reden die vaak genoemd werd en die in de tweede helft van 2014 iets in belang toenam is het vrijwillige vertrek van personeel. Deze toename in vrijwillige mobiliteit tekent eveneens de aantrekkende arbeidsmarkt, waarin werknemers ook weer meer kansen bij andere bedrijven zien.

FIGUUR 3.3 Ontstaansreden van vacatures voor technici, 2012-2014

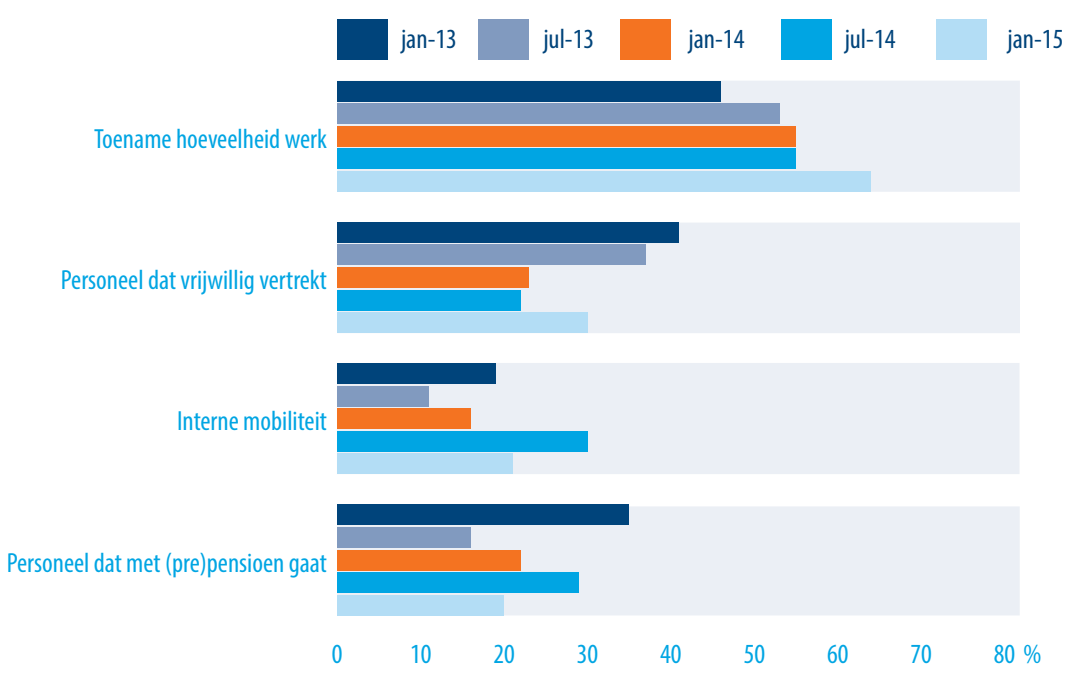

Bron: ROA, Arbeidsmarktmonitor Metalektro, 2012-2014

Noot: In de figuur zijn alleen ontstaansredenen opgenomen die voor ten minste één van de metingen door minimaal $5 \%$ van de bedrijven zijn genoemd. Ontstaansredenen die door minder dan 5\% genoemd werden zijn: één of meer werknemers zijn tijdelijk niet inzetbaar en één of meer werknemers zijn minder gaan werken

\section{Steeds meer bedrijven zijn in staat proactief vacatures te openen}

De ontstaansredenen voor vacatures kunnen verder onderzocht worden door te bestuderen of vacatures ontstaan als gevolg van een bestaande situatie of een verwachte toekomstige situatie. Als een vacature binnen een bedrijf ontstaat als gevolg van een actuele vraag naar personeel, dan is er sprake van een reactief vacaturebeleid. Ontstaat de vacature binnen het bedrijf echter doordat het bedrijf anticipeert op toekomstige vraag naar personeel, dan spreken we van een proactief vacaturebeleid. Voor de laatste vier halve jaren is in Figuur 3.4 het percentage bedrijven weergegeven dat proactief vacatures opende.

Voor alle ontstaansredenen van vacatures die in Figuur 3.4 zijn weergeven, geldt dat er aan het eind van 2014 meer vacatures proactief werden geopend dan aan het begin van 2014. Bedrijven spelen het vaakst (58\%) proactief in op medewerkers die met (pre) pensioen gaan. Dit is logisch, aangezien pensionering iets is dat werkgever en werk- 
nemer in de meeste gevallen zullen zien aankomen. Toch lag het percentage bedrijven dat hierop proactief wist in te spelen zelden zo hoog als in de tweede helft van 2014. Vacatures die ontstonden als gevolg van een toename van de hoeveelheid werk werden in de tweede helft van 2014 ook relatief vaak proactief geopend (55\%). Met uitzondering van de meting in juli 2014 was er in deze categorie sprake van een toename in het aandeel bedrijven dat vacatures proactief opende. Vacatures die ontstonden als gevolg van interne mobiliteit werden in $38 \%$ van de gevallen proactief geopend. Het aandeel vacatures dat proactief wordt geopend neemt al een tijdje gestaag toe in deze categorie. Vacatures die ontstaan als gevolg van vrijwillig vertrek van bestaand personeel worden relatief gezien het minst vaak proactief geopend. Dergelijke vacatures zijn dikwijls lastig te voorspellen.

FIGUUR 3.4 Percentage bedrijven dat proactief vacatures opende, naar ontstaansreden van vacatures, 2013-2014

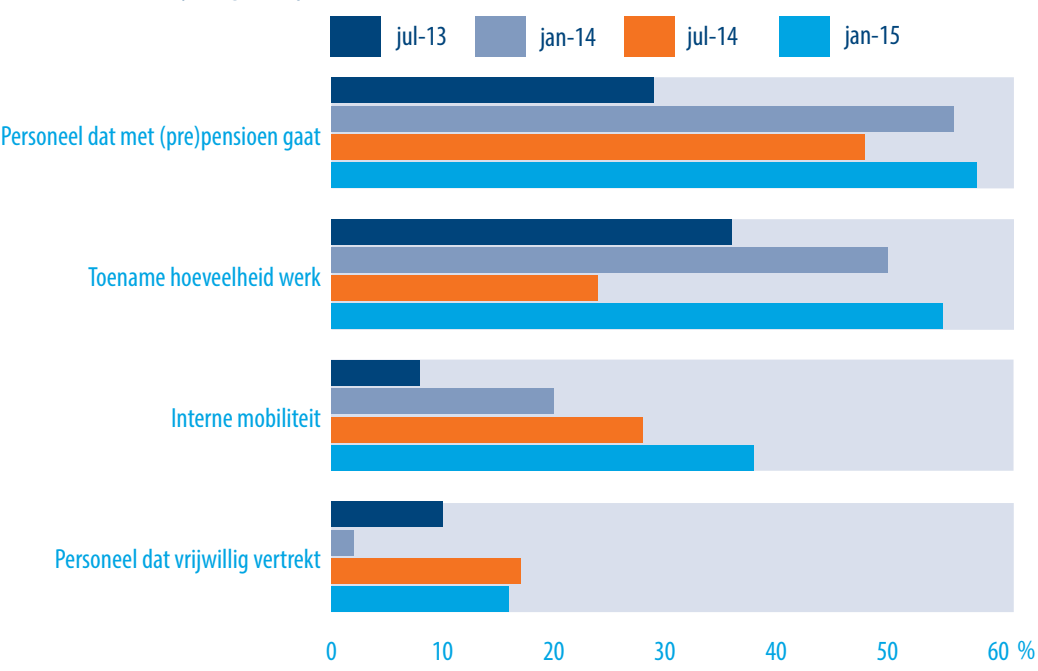

Bron: ROA, Arbeidsmarktmonitor Metalektro, 2013-2014 
Bij Royal Smit Transformers B.V. speelt men proactief in op de behoefte aan goed opgeleide technici in de toekomst. Mèlanie Jansen-van Lendt, senior personeelsfunctionaris bij Royal Smit Transformers B.V., wijst op het BBL-traject Mechatronica dat in samenwerking met Werk en Vakmanschap, een ROC en verschillende technische bedrijven uit de regio Nijmegen is opgezet. Mede door deze opleiding is er sprake van een proactief wervingsbeleid. Smit selecteert jaarlijks een aantal leerlingen voor deze opleiding en hoopt deze jongeren in de toekomst, als ze klaar zijn met hun opleidingstraject en vanaf dat moment volledig inzetbaar zijn, in dienst te kunnen houden. Bij de werving van leerlingen voor de BBL-opleiding wordt daarom niet alleen gekeken naar de huidige behoefte aan goed opgeleide jonge technici, maar ook naar de toekomstige behoefte aan goed opgeleide technici: "we proberen de klas om die reden ook altijd te vullen, zelfs in crisistijd", geeft mevrouw Jansen-van Lendt aan. Ze wijst er bovendien op dat deze manier van proactief werven ook een goede manier is om te anticiperen op de vergrijzing van de Nederlandse beroepsbevolking.

\subsection{Grote verschillen in gebruik en effectiviteit van wervingskanalen}

Voor het werven van nieuwe werknemers kan gebruik gemaakt worden van een divers scala aan wervingskanalen. Figuur $3.5 \mathrm{geeft}$ een overzicht van het percentage bedrijven dat een bepaald wervingskanaal toepast voor het aantrekken van lager en middelbaar opgeleide technici (horizontale as). Voor het aantrekken van lager en middelbaar opgeleide technici is het uitzendbureau het vaakst gekozen wervingskanaal. Ruim zes op de tien bedrijven maakt gebruik van dit kanaal. Ook werving via personeel in de eigen bedrijfsvestiging en open sollicitaties blijken populaire wervingskanalen te zijn voor deze groep technici. Deze twee wervingskanalen worden beide door ongeveer de helft van de bedrijven toegepast. Naast de toepassing van verschillende wervingskanalen is in deze figuur ook per wervingskanaal aangeven hoeveel procent van de bedrijven dit wervingskanaal als meest effectieve wervingskanaal beschouwt (verticale as). Er is sprake van een positief verband tussen het gebruik en de effectiviteit van een wervingskanaal. Dit betekent dat wervingskanalen die relatief goed scoren op effectiviteit over het algemeen ook vaker worden toegepast (en vice versa). Zelfs als we het uitzendbureau buiten beschouwing laten (een wervingskanaal dat hoog scoort op beide dimensies), blijft er nog een (zwak) positief verband over. Een illustratie waarom het uitzendbureau zo vaak wordt gebruikt en effectief kan bijdragen aan verlaging van de interne werklast wordt in Tekstbox 3.2 gegeven. 
TEKSTBOX 3.2 Waarom Royal Smit Transformers B.V. werkt met een uitzendbureau in plaats van tijdelijke contracten

In plaats van contracten voor een half jaar aan te bieden maakt Smit gebruik van uitzendbureaus om tijdelijke functies in te vullen. Bij dit type dienstverband is vaak sprake van een wat hogere uitstroom (voornamelijk als gevolg van de korte duur waarvoor deze mensen worden aangenomen). $0 \mathrm{~m}$ de HRM-afdeling van Smit te ontlasten wordt om die reden dan ook gebruik gemaakt van uitzendbureaus en werving- en selectiebureaus. Hierdoor wordt de eerste selectie van kandidaten uitbesteed en hoeft Smit nog maar te kiezen uit een drietal uiteindelijke kandidaten.

FIGUUR 3.5 Gebruik en effectiviteit van verschillende wervingskanalen voor lager en middelbaar opgeleide technici (\% bedrijven), 2014

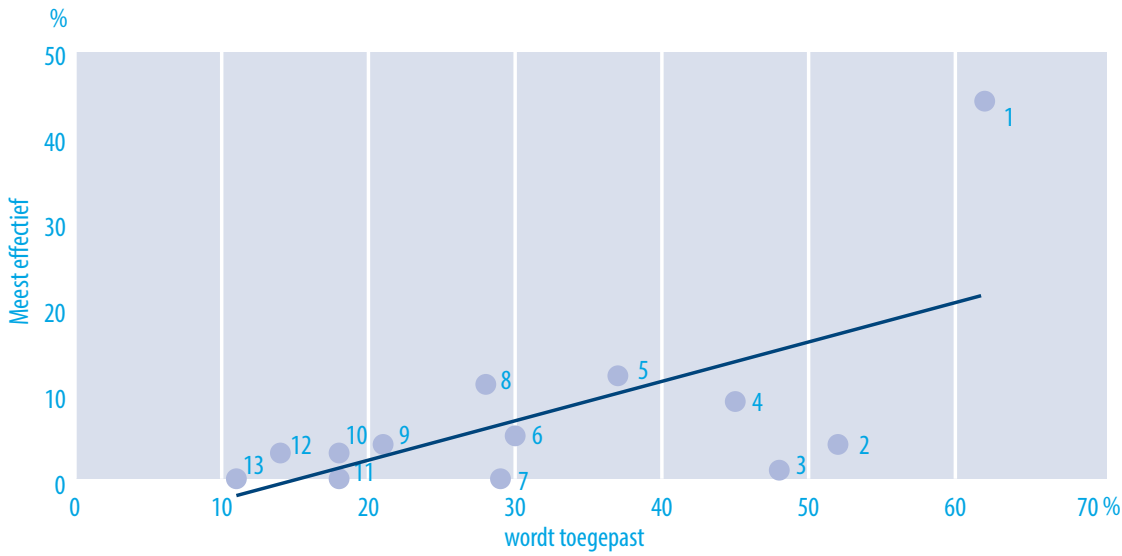

Bron: ROA, Arbeidsmarktmonitor Metalektro, 2014

Noot: 1. Uitzendbureau

2. Eigen personeel in deze bedrijfsvestiging

3. Open sollicitaties

4. Informele kanalen

5. School/opleiding

6. Online vacaturebank(en) (bijv. Monsterboard)

7. Externe relaties

8. Advertentie in regionaal dagblad

9. UWV WERKbedrijf (voormalig CWI)

10. Detacheringsbureau

11. Sociale media

12. Commercieel werving- en selectiebureau

13. Personeel in de andere bedrijfsvestiging(en)

Figuur 3.5 toont ook enkele wervingskanalen die relatief vaak worden toegepast, maar tegelijkertijd als weinig effectief worden beschouwd, zoals het werven via personeel in de eigen bedrijfsvestiging en via open sollicitaties. Een verklaring voor het verhoudings- 
gewijs relatief hoge gebruik van deze wervingskanalen moet waarschijnlijk gezocht worden in de relatief lage kosten van deze wervingskanalen. Deze wervingskanalen zijn zo laagdrempelig en goedkoop in te zetten dat een lagere effectiviteit kennelijk vaak voor lief wordt genomen.

FIGUUR 3.6 Gebruik en effectiviteit van verschillende wervingskanalen voor hoger opgeleide technici (\% bedrijven), 2014

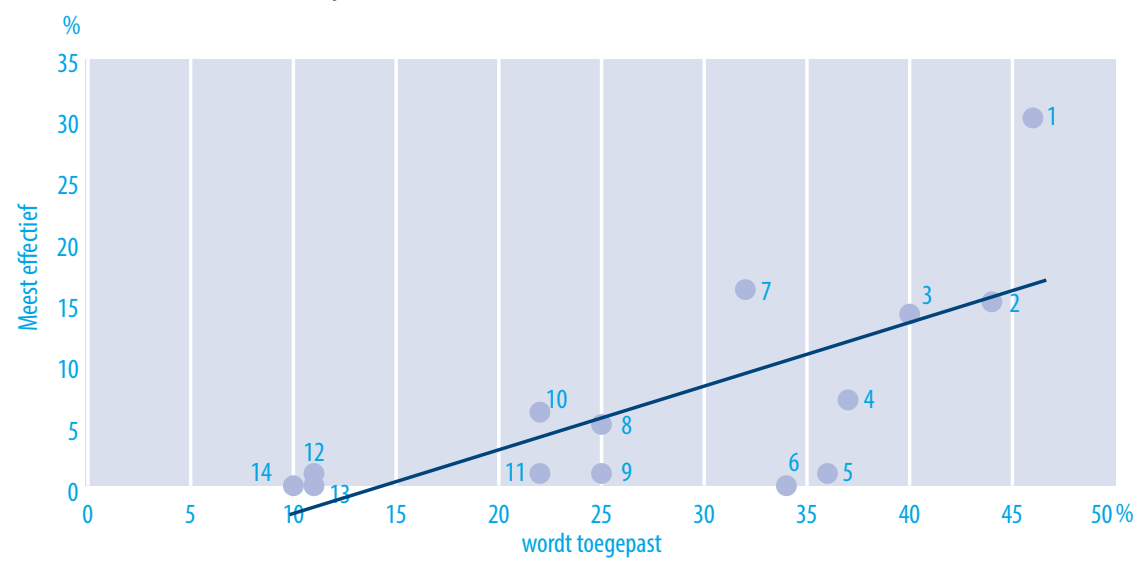

Bron: ROA, Arbeidsmarktmonitor Metalektro, 2014

Noot: 1. Commercieel werving- en selectiebureau

2. Informele kanalen

3. Online vacaturebank(en) (bijv. Monsterboard)

4. Externe relaties

5. Eigen personeel in deze bedrijfsvestiging

6. Open sollicitaties

7. Detacheringsbureau

8. Sociale media

9. Uitzendbureau

10. Advertentie in regionaal dagblad

11. School/opleiding

12. UWV WERKbedrijf (voormalig CWI)

13. Personeel in de andere bedrijfsvestiging(en)

14. Advertentie in landelijk dagblad

De rangorde van meest gebruikte wervingskanalen voor het aantrekken van hoger opgeleide technici verschilt significant van die voor het aantrekken van lager en middelbaar opgeleide technici. Dit is te zien in Figuur 3.6. Het meest gebruikte wervingskanaal voor de werving van hoger opgeleide technici is het commercieel werving- en selectiebureau dat door bijna de helft van de bedrijven wordt toegepast. Ook het inschakelen van een detacheringsbureau of het werven via informele kanalen zijn populair. De figuur toont wederom ook het percentage bedrijven dat deze kanalen als meest effectief beschouwt. 
Ook hier zien we een positief verband tussen de mate waarin een bepaald wervingskanaal wordt toegepast en de mate waarin dit kanaal als effectief wordt beschouwd. Opvallend is dat het positieve verband tussen deze twee dimensies hier sterker aanwezig is dan in Figuur 3.5. Metalektrobedrijven lijken dus effectiever gebruik te maken van de verschillende wervingskanalen voor hoger opgeleide technici. Een wervingskanaal dat echter relatief vaak wordt genoemd als meest effectief voor het werven van hoger opgeleide technici, maar waarvan verhoudingsgewijs weinig gebruik wordt gemaakt is het inschakelen van een detacheringsbureau. Hier spelen de relatief hoge kosten van het inschakelen van een detacheringsbureau waarschijnlijk een belangrijke rol. Een vergelijking van Figuur 3.5 met Figuur 3.6 maakt duidelijk dat er grote verschillen zijn in zowel het gebruik als de effectiviteit van de verschillende wervingskanalen tussen opleidingsgroepen. Het meest in het oog springende verschil is het feit dat uitzendbureaus vaak worden toegepast en bovendien vaak als effectief worden beschouwd voor het werven van lager en middelbaar opgeleide technici, maar veel minder worden toegepast en als nauwelijks effectief worden beschouwd voor het werven van hoger opgeleide technici. Voor commerciële werving- en selectiebureaus geldt dit precies andersom.

\subsection{Internetwerving populairder en effectiever voor werving van hoger opgeleide technici}

Eén van de media om nieuw personeel te werven is het internet. Hierbij kan men onder meer denken aan het gebruik van online vacaturebanken en sociale media. Figuur 3.7a laat het percentage metalektrobedrijven zien dat gebruik maakt van deze twee kanalen voor de werving van lager en middelbaar, dan wel hoger opgeleid personeel. Voor het werven van hoger opgeleide technici wordt significant vaker gebruik gemaakt van zowel online vacaturebanken als sociale media. Beide kanalen worden ook significant vaker als meest effectieve kanalen gekozen voor het werven van hoger opgeleide technici, zoals is te zien in Figuur 3.7b. Desondanks is het percentage bedrijven dat online vacaturebanken als effectiefste wervingskanaal voor de werving van hoger opgeleide technici beschouwt nog altijd maar $14 \%$. Hierbij geldt dat vooral grote bedrijven vaker gebruik maken van online vacature banken en sociale media bij het werven van hoger opgeleide technici dan MKB-bedrijven. 
FIGUUR 3.7a Gebruik van online vacaturebank(en) en sociale media naar opleidingsniveau (\% bedrijven), 2014

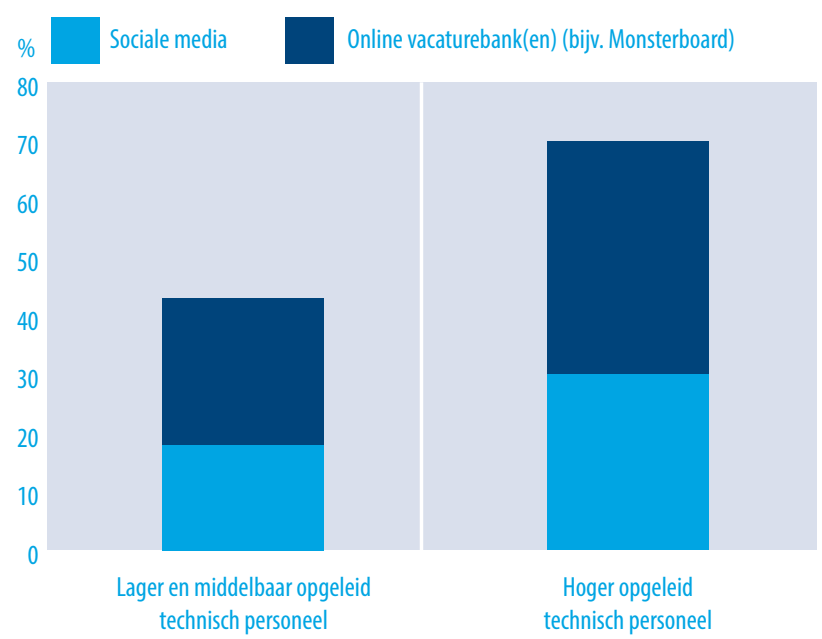

Bron: ROA, Arbeidsmarktmonitor Metalektro, 2014

FIGUUR 3.7b Effectiviteit van online vacaturebank(en) en sociale media naar opleidingsniveau (\% bedrijven), 2014

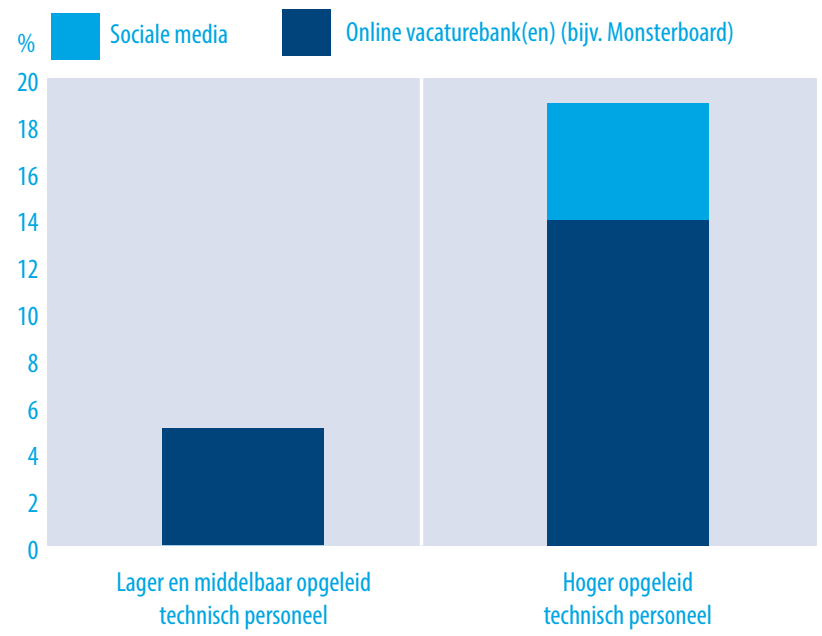

Bron: ROA, Arbeidsmarktmonitor Metalektro, 2014

\subsection{LinkedIn populairste sociale mediakanaal voor werven van technici}

Figuur 3.8 gaat voor beide opleidingsniveaus specifieker in op wélke sociale media het meest worden ingezet voor de werving. Voor de werving van beide groepen technici 
wordt Linkedln het meest gebruikt. Voor het werven van hoger opgeleide technici wordt echter relatief vaker gebruik gemaakt van Linkedln dan voor het werven van lager en middelbaar opgeleide technici, terwijl voor het werven van technici uit deze laatste groep relatief vaker gebruik wordt gemaakt van Facebook en Twitter. Bedrijven in de regio Noord/Oost maken significant minder gebruik van Linkedln als wervingskanaal voor lager en middelbaar opgeleide technici dan bedrijven in de rest van het land. Het verschil is aanzienlijk: Slechts $18 \%$ van de bedrijven in Noord/Oost maakt gebruik van dit kanaal voor het werven van lager en middelbaar technisch opgeleid personeel, tegenover $89 \%$ in het Zuiden en $90 \%$ in het Westen. Signalen vanuit de sector wijzen er op dat dit mogelijk met regionale cultuurverschillen te maken heeft, waarbij Linkedln voornamelijk een Randstedelijk fenomeen lijkt te zijn.

FIGUUR 3.8 Gebruik van verschillende sociale media voor werving, naar opleidingsniveau (\% bedrijven)

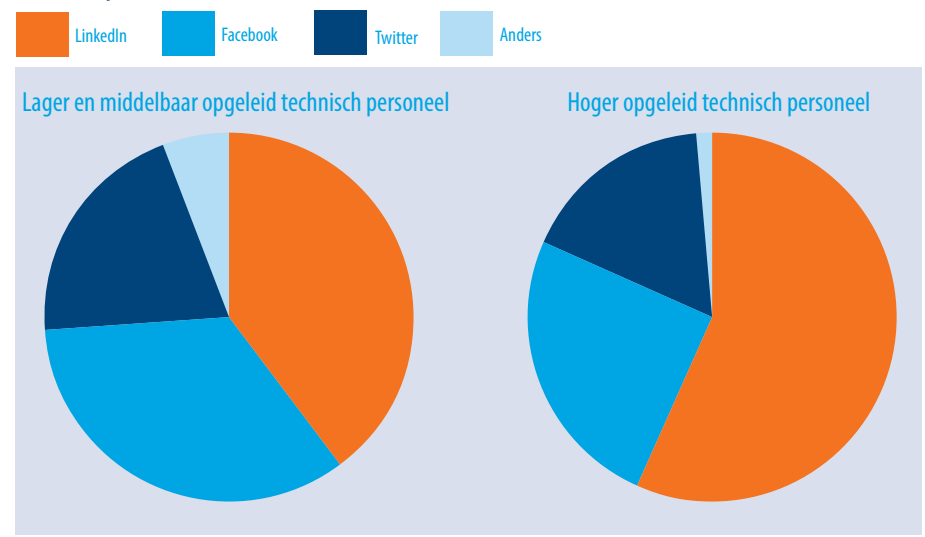

Bron: ROA, Arbeidsmarktmonitor Metalektro, 2014

\subsection{Weer minder bedrijven met wervingsproblemen in 2014}

Het percentage metalektrobedrijven dat (erg) veel wervingsproblemen ervaart bij het vinden van technisch personeel is in 2014 wederom licht, maar statistisch significant gedaald. Dit toont Figuur 3.9. Het percentage bedrijven dat aangaf geen of nauwelijks wervingsproblemen te ondervinden bleef gelijk en het percentage bedrijven dat een gemiddeld aantal wervingsproblemen ondervond nam licht toe. Globaal is er dus sprake van een lichte verbetering, maar deze verbetering is minder sterk dan in 2013. Toen daalde zowel het percentage bedrijven met (erg) veel wervingsproblemen als het percentage bedrijven met gemiddelde wervingsproblemen. 


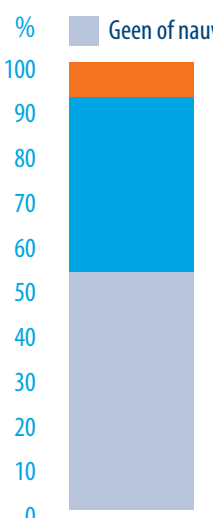

2009

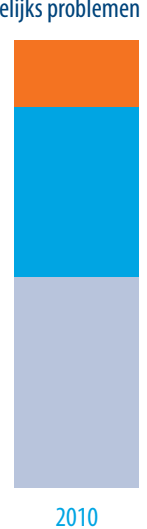

2010
Gemiddeld

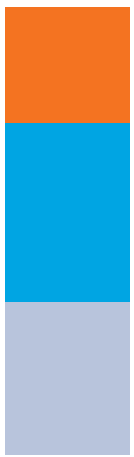

2011
(Erg) veel problemen

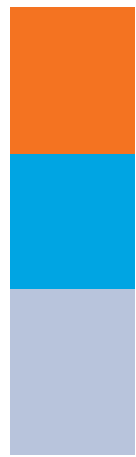

2012

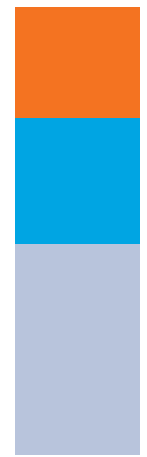

2013

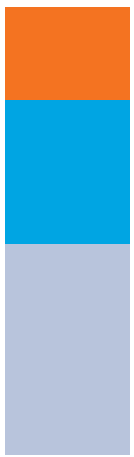

2014

Bron: ROA, Arbeidsmarktmonitor Metalektro, 2014

In de Figuren 3.10, 3.11 en 3.12 gaan we dieper in op de bedrijven die aan hebben gegeven gemiddeld, veel of erg veel problemen te ondervinden bij het werven van technisch personeel. De bedrijven die geen of nauwelijks problemen hadden bij het werven van technici zijn buiten beschouwing gelaten. Om een beter inzicht te verkrijgen in de wervingsproblemen die wel werden ervaren is er in Figuur 3.10 een verbijzondering gemaakt naar verschillende typen technisch personeel en in Figuren 3.11 en 3.12 een verbijzondering naar regio en bedrijfsgrootte.

Uit Figuur 3.10 blijkt dat wervingsproblemen zich vooral voordoen bij uitvoerende technische functies en engineering en R\&D functies. Bijna de helft van de bedrijven met gemiddeld of (erg) veel wervingsproblemen geeft aan dat dit (onder meer) uitvoerende technische functies betreft. Voor engineering en R\&D functies ligt dit percentage in 2014 op 39\% en voor de drie andere functiecategorieën tussen de $10 \%$ en $20 \%$. Aangezien engineering en R\&D personeel in 2013 voor het eerst als aparte functiecategorie werd onderscheiden is $\mathbf{2 0 1 4}$ het eerste jaar waarvoor we een jaar-op-jaar verandering kunnen laten zien voor deze functiecategorie. De stijging is aanzienlijk. Terwijl in 2013 nog maar $28 \%$ van de bedrijven aangaf dat zij problemen hadden bij het vinden van engineering en R\&D personeel, is dit in 2014 al bijna 40\% van de bedrijven. Indien de ontwikkelingen in Figuur 3.10 de komende jaren doorzetten, is het goed mogelijk dat de wervingsproblemen bij engineering en R\&D personeel groter zullen worden dan die voor uitvoerende technische functies. 
FIGUUR 3.10 Percentage bedrijven met problemen bij het vinden van technici, naar functiecategorie, 2008-2014

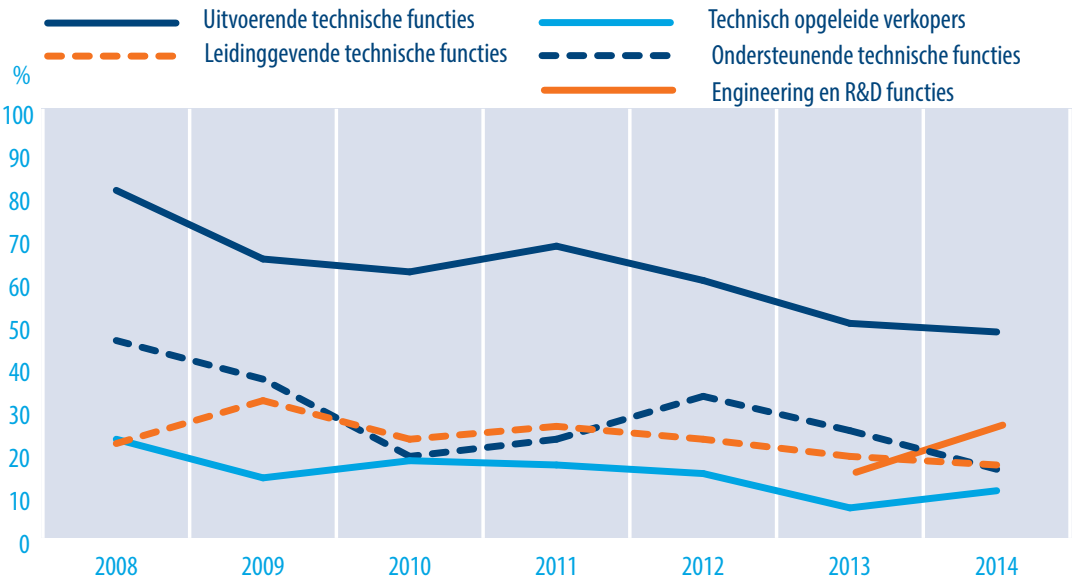

Bron: ROA, Arbeidsmarktmonitor Metalektro, 2008-2014

De Figuren 3.11 en 3.12 maken de verschillen tussen regio's en kleinere versus grote bedrijven inzichtelijk. Het meest opvallende verschil tussen de regio's (Figuur 3.11) is dat de wervingsproblemen in de regio Noord/Oost relatief minder vaak betrekking hebben op leidinggevende technische functies, maar juist vaker op het vinden van ondersteunende technici dan in de rest van het land. In de regio Zuid hebben bedrijven relatief vaker moeite met het vinden van technisch opgeleide verkopers en engineering en $R \& D$ personeel en in de regio West relatief vaker met het vinden van uitvoerende technici. Naast deze regionale verschillen zijn er ook enkele accentverschillen tussen grote bedrijven en MKB-bedrijven (Figuur 3.12). In vergelijking met grote bedrijven hebben MKB-bedrijven namelijk relatief vaker problemen met het vinden van uitvoerende technici en juist minder met het vinden van ondersteunende en leidinggevende technici. 
FIGUUR 3.11 Problemen bij het vinden van technici naar regio en functiecategorie (\% bedrijven), 2014
Uitvoerende technische functies
Leidinggevende technische functies
Technisch opgeleide verkopers
Ondersteunende technische functies
Engineering en R\&D functies

$\%$

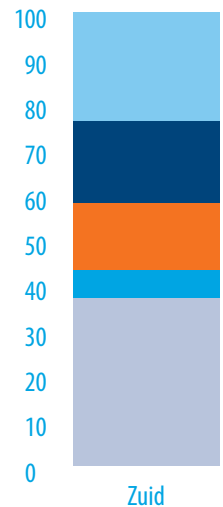

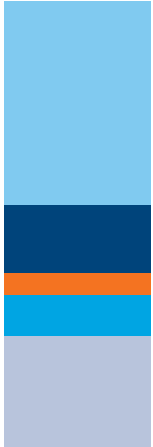

West

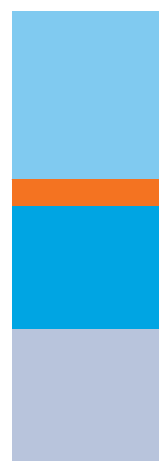

Noord/0ost

Bron: ROA, Arbeidsmarktmonitor Metalektro, 2014

FIGUUR 3.12 Problemen bij het vinden van technici naar bedrijfsgrootte en functiecategorie (\% bedrijven), 2014

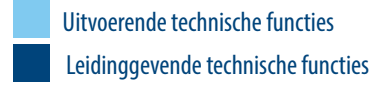

$\%$

100

90

80

70

60

50

40

30

20

10

0

MKB-bedrijven

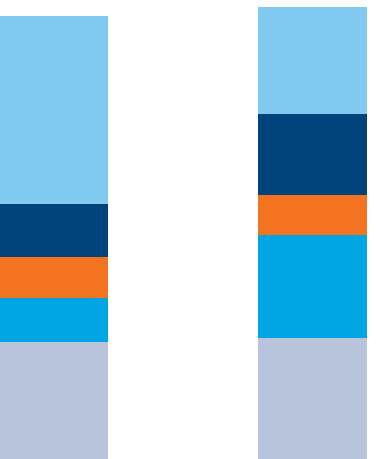

Grote bedrijven
Technisch opgeleide verkopers

Ondersteunende technische functies

Engineering en $R \& D$ functies

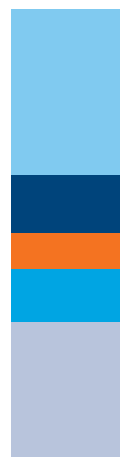

Totaal

Bron: ROA, Arbeidsmarktmonitor Metalektro, 2014

\subsection{De oorzaken en gevolgen van wervingsproblemen}

Figuur 3.13 toont wat metalektrobedrijven vanaf 2011 als de belangrijkste oorzaken voor de wervingsproblemen zien. De rangorde van de meest genoemde oorzaken is 
al jaren min of meer hetzelfde. Het vaakst wordt genoemd dat sollicitanten niet over de juiste competenties beschikken. Een te laag aanbod van sollicitanten scoort ook al jaren erg hoog, maar wordt de laatste jaren steeds minder vaak genoemd. Dit is niet vreemd gezien het feit dat het aantal werkzoekenden op macroniveau de laatste jaren fors is toegenomen. Ook heeft nog altijd een derde van de metalektrobedrijven te maken met sollicitanten met onvoldoende ervaring. Te weinig aanbod vanuit opleidingen wordt door een vijfde van de bedrijven genoemd. Het percentage bedrijven dat aangeeft dat sollicitanten te hoge salariseisen stellen lijkt het afgelopen jaar weer iets te zijn toegenomen, maar het verschil met 2013 blijkt niet statistisch significant. Een aantal van deze oorzaken ${ }^{5}$ zouden minder vaak genoemd worden als er meer jongeren in zouden stromen in de technische opleidingen, die daarna ook in de techniek werkzaam zouden willen zijn. Verschillende metalektrobedrijven zetten zich daarom expliciet in om jongeren te enthousiasmeren voor technische beroepen. Tekstbox 3.3 geeft hiervan twee voorbeelden.

FIGUUR 3.13 Belangrijkste oorzaken van de wervingsproblemen voor technici (\% bedrijven), 20112014

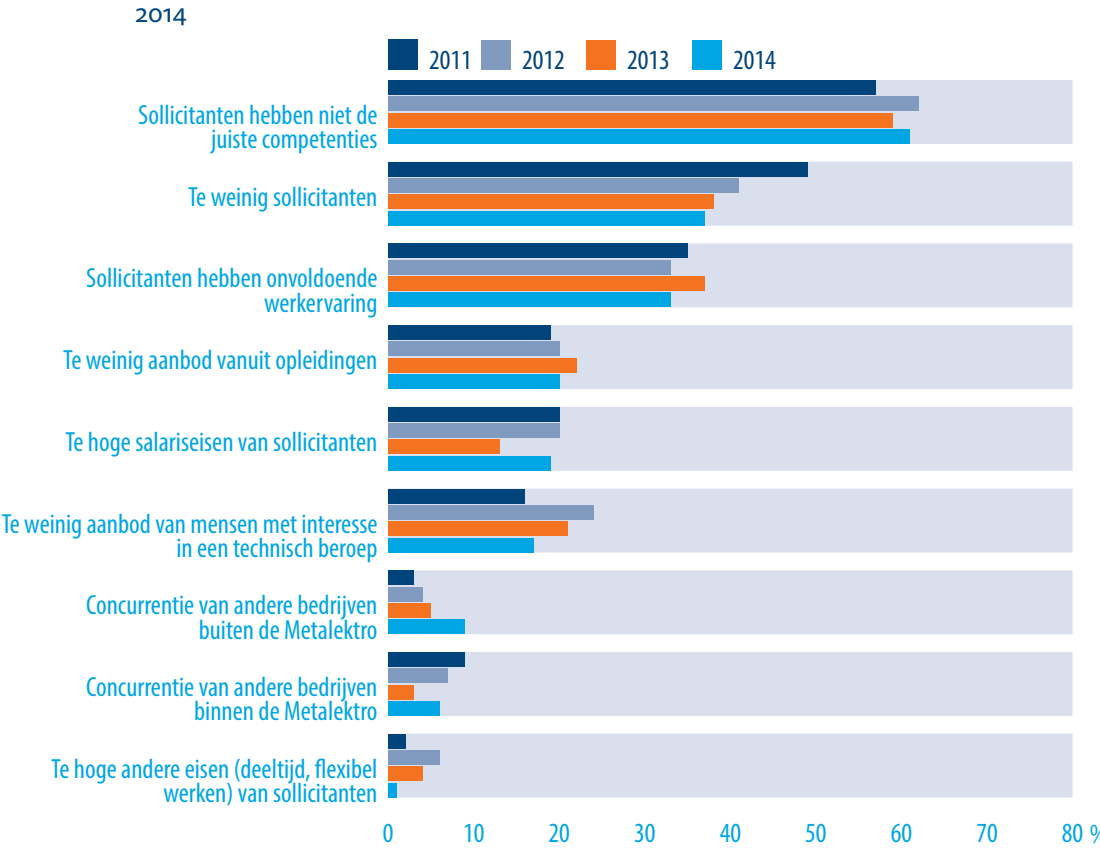

Bron: ROA, Arbeidsmarktmonitor Metalektro, 2011-2014

Noot: In de jaren 2011, 2012 en 2013 werd gevraagd naar de oorzaken van de wervingsproblemen in de afgelopen 6 maanden, terwijl sinds 2014 wordt gevraagd naar de afgelopen 12 maanden.

5 Met name de oorzaken 'Te weinig sollicitanten, te weinig aanbod vanuit opleidingen en te weinig aanbod van mensen met interesse in een technisch beroep'. 
Herman van der Donk, HR-manager bij Ardagh in Deventer, beseft dat het belangrijk is om jongeren te enthousiasmeren voor techniek en technische beroepen. Hij wijst op het initiatief van de techniekcampus Deventer, een samenwerkingsverband in de stedendriehoek van Deventer, Apeldoorn en Zutphen. Deze campus moet hét opleidings- en innovatiecentrum voor techniek in de regio worden. Het betreft een samenwerkingsverband van bedrijven in 0.a. de bouw, metalektro, metaal- en installatietechniek en een ROC. De samenwerkende organisaties voeren geregeld overleg over onder andere het curriculum en de doelmatigheid van de techniekcampus. Daarnaast proberen de deelnemende bedrijven hun activiteiten (bijvoorbeeld de promotie van technische beroepen) beter af te stemmen. Volgens Van der Donk heeft de techniekcampus en de toegenomen samenwerking tussen bedrijven uit de regio geleid tot zowel een toename van het aantal leerlingen dat kiest voor techniek als een toename van de kwaliteit van jonge technici in de regio. Hij is van mening dat techniekbedrijven zich nog meer moeten inspannen om te laten zien dat techniek leuk is: "Er moet voldoende aanwas zijn van nieuwe technici, zowel voor nu als in de toekomst. Het gaat hierbij om techniek op alle niveaus; van handwerk tot academisch geschoolde technici". Het is volgens hem goed nieuws dat jongeren en hun ouders zich in toenemende mate realiseren dat de techniek toekomst biedt en minder conjunctuurgevoelig is dan sommige andere sectoren.

Mèlanie Jansen-van Lendt, senior personeelsfunctionaris bij Royal Smit Transformers B.V., geeft aan dat Royal Smit zich in toenemende mate inspant om jongeren al vroeg te enthousiasmeren voor de techniek. In samenwerking met Werk en Vakmanschap bezoekt $S$ mit veel basisscholen (met name groep 8) en VMBO-scholen om technische beroepen in het algemeen en het werken bij Smit in het bijzonder, te promoten. In dit kader is er ook veel samenwerking met andere bedrijven in en rondom Nijmegen, bijvoorbeeld door de aanwezigheid op allerlei evenementen waar techniek gepromoot wordt onderling te coördineren. Denk daarbij aan de techniekweek Nijmegen waar de regionale bedrijven goed vertegenwoordigd zijn, maar ook de bedrijvenontmoetingsavonden voor het middelbare onderwijs. $0 \mathrm{p}$ deze avonden kunnen leerlingen kennismaken met diverse beroepen waaronder dus ook technische beroepen. Naast het feit dat bedrijven hun krachten op deze manier kunnen bundelen om jongeren te enthousiasmeren voor technische beroepen, wijst Jansen-van Lendt op het feit dat het door de toenemende samenwerking met bedrijven uit de regio makkelijker is geworden om technici te behouden voor de regio. Zo kunnen bedrijven met uitstroom en bedrijven met vacante posities elkaar helpen door goed samen te werken.

\section{Toegenomen werkdruk vaakst genoemde gevolg van niet-ingevulde vacatures}

Ondanks het feit dat het percentage bedrijven dat (erg) veel wervingsproblemen ondervond in 2014 licht afnam, zijn er nog altijd wel vacatures die relatief lang open staan en niet binnen afzienbare termijn kunnen worden ingevuld. Ongeveer één op de drie bedrijven (34\%) geeft hierbij aan dat niet-ingevulde vacatures voor technici direct merkbare gevolgen hebben voor het bedrijf. Dit is een significante toename ten opzichte van 2013 , toen $26 \%$ van de metalektrobedrijven met lang openstaande vacatures geconfronteerd werd met direct merkbare gevolgen. Deze toename in direct merkbare gevolgen in 2014 valt samen met een hoger percentage bedrijven dat aangeeft dat ontstane 
vacatures het gevolg zijn van een toename in de hoeveelheid werk (zie Figuur 3.3). Dit illustreert dat de direct merkbare gevolgen van niet-ingevulde vacatures voor technici toenemen, als bedrijven tevens worden geconfronteerd met een toegenomen hoeveelheid werk. Om inzicht te krijgen in de directe gevolgen die bedrijven ervaren worden de vijf meest genoemde gevolgen voor de afgelopen jaren weergeven in Tabel 3.1.

TABEL 3.1 Top 5 gevolgen van niet-ingevulde vacatures, 2011-2014

\begin{tabular}{|c|c|c|c|c|}
\hline $\begin{array}{l}\text { Top } 5 \\
\text { per jaar }\end{array}$ & 2011 & 2012 & 2013 & 2014 \\
\hline 1 & $\begin{array}{l}\text { Toegenomen werkdruk } \\
(88 \%)\end{array}$ & $\begin{array}{l}\text { Toegenomen werkdruk } \\
(70 \%)\end{array}$ & $\begin{array}{l}\text { Toegenomen werkdruk } \\
(70 \%)\end{array}$ & $\begin{array}{l}\text { Toegenomen werkdruk } \\
(87 \%)\end{array}$ \\
\hline 2 & $\begin{array}{l}\text { Werk blijft liggen / } \\
\text { deadlines gemist (45\%) }\end{array}$ & $\begin{array}{l}\text { Werk blijft liggen / } \\
\text { deadlines gemist (47\%) }\end{array}$ & $\begin{array}{l}\text { Werk blijft liggen / } \\
\text { deadlines gemist (53\%) }\end{array}$ & $\begin{array}{l}\text { Werk blijft liggen / } \\
\text { deadlines gemist (35\%) }\end{array}$ \\
\hline 3 & $\begin{array}{l}\text { Hogere kosten doordat } \\
\text { werk moet worden } \\
\text { uitbesteed }(29 \%)\end{array}$ & $\begin{array}{l}\text { Hogere kosten doordat } \\
\text { werk moet worden } \\
\text { uitbesteed }(28 \%)\end{array}$ & $\begin{array}{l}\text { Levertijden worden langer } \\
(32 \%)\end{array}$ & $\begin{array}{l}\text { Levertijden worden langer } \\
(31 \%)\end{array}$ \\
\hline 4 & $\begin{array}{l}\text { Hogere wervings- of } \\
\text { opleidingskosten (24\%) }\end{array}$ & Verlies aan orders ( $25 \%)$ & $\begin{array}{l}\text { Minder mogelijkheden om } \\
\text { te innoveren }(31 \%)\end{array}$ & $\begin{array}{l}\text { Minder mogelijkheden om } \\
\text { te innoveren }(26 \%)\end{array}$ \\
\hline 5 & $\begin{array}{l}\text { Levertijden worden langer } \\
(20 \%)\end{array}$ & $\begin{array}{l}\text { Vermindering van de } \\
\text { kwaliteit van de productie } \\
(22 \%)\end{array}$ & $\begin{array}{l}\text { Hogere kosten doordat } \\
\text { werk moet worden } \\
\text { uitbesteed }(23 \%)\end{array}$ & $\begin{array}{l}\text { Hogere kosten doordat } \\
\text { werk moet worden } \\
\text { uitbesteed }(26 \%)\end{array}$ \\
\hline
\end{tabular}

Bron: ROA, Arbeidsmarktmonitor Metalektro, 2011-2014

De top vijf is qua volgorde niet veranderd ten opzichte van 2013. Net als in voorgaande jaren leiden niet-ingevulde vacatures vooral tot een toename in de werkdruk en tot werk dat blijft liggen of gemiste deadlines. In vergelijking met 2013 wordt het toenemen van de werkdruk echter een stuk vaker genoemd, terwijl het percentage bedrijven dat aangeeft dat werk blijft liggen/ men deadlines mist juist afneemt. Het langer worden van de levertijden staat net als in 2013 op de derde plaats. Positief is het feit dat het percentage bedrijven dat aangeeft dat er minder mogelijkheden zijn om te innoveren als gevolg van niet-ingevulde technische vacatures in 2014 is afgenomen. Deze daling is enigszins opmerkelijk aangezien we eerder zagen dat het percentage bedrijven dat problemen ondervond bij het vinden van engineering en R\&D personeel - een functiecategorie die normaal gesproken één van de drijvende krachten achter innovatie binnen de bedrijven zal zijn - juist toenam in 2014. Kennelijk verwachten bedrijven niet direct dat de toegenomen moeilijkheden bij het werven van engineering en R\&D personeel leidt tot minder mogelijkheden om te innoveren. Desalniettemin geeft nog steeds een aanzienlijk aandeel van de bedrijven aan dat minder innovatiemogelijkheden een direct gevolg is van niet-ingevulde vacatures voor technisch personeel. Aangezien het thema innovatie een peiler is voor de toekomst van de Metalektro verdient dit nadrukkelijk de aandacht. Hogere kosten doordat werk moet worden uitbesteed is ook al jaren een vaak genoemd direct gevolg van niet-ingevulde vacatures. Het aandeel bedrijven dat dit gevolg in 2014 noemt wijkt niet significant af van 2013. De percentages in de top vijf 
tellen binnen een jaar niet op tot 100\%. Dat betekent dat bedrijven dikwijls aangeven dat ze meerdere van deze gevolgen van niet-ingevulde vacatures ondervinden.

In Tabel 3.2 worden de oorzaken en gevolgen van de problemen bij het vinden van technici aan elkaar gekoppeld. De rijen van de tabel geven de oorzaken en de kolommen de gevolgen. De cijfers in de tabel verwijzen naar het percentage bedrijven dat een bepaald gevolg rapporteert bij de oorzaak genoemd in de bijbehorende rij. De $86 \%$ in de eerste cel verwijst dus naar het percentage bedrijven dat een toegenomen werkdruk noemt als gevolg, onder de voorwaarde dat deze bedrijven te weinig aanbod vanuit de opleidingen als (één van de) oorzaak(en) hebben genoemd.

TABEL 3.2 Verbanden tussen oorzaken en gevolgen van niet-ingevulde vacatures, 2014

\begin{tabular}{|c|c|c|c|c|c|}
\hline $\begin{array}{l}\text { Oorzaken (rijen) en } \\
\text { gevolgen (kolommen) van } \\
\text { problemen bij het vinden } \\
\text { van technici }\end{array}$ & $\begin{array}{l}\text { Toegenomen } \\
\text { werkdruk }\end{array}$ & $\begin{array}{l}\text { Werk blijft liggen } \\
\text { / deadlines } \\
\text { worden gemist }\end{array}$ & $\begin{array}{l}\text { Levertijden } \\
\text { worden langer }\end{array}$ & $\begin{array}{l}\text { Minder mogelijk- } \\
\text { heden om te } \\
\text { innoveren }\end{array}$ & $\begin{array}{l}\text { Hogere kosten } \\
\text { doordat werk } \\
\text { moet worden } \\
\text { uitbesteed }\end{array}$ \\
\hline $\begin{array}{l}\text { Te weinig aanbod vanuit } \\
\text { opleidingen }\end{array}$ & $86 \%$ & $41 \%$ & $32 \%$ & $9 \%$ & $47 \%$ \\
\hline Te weinig sollicitanten & $97 \%$ & $35 \%$ & $10 \%$ & $44 \%$ & $21 \%$ \\
\hline $\begin{array}{l}\text { Onvoldoende } \\
\text { werkervaring sollicitanten }\end{array}$ & $78 \%$ & $44 \%$ & $30 \%$ & $29 \%$ & $20 \%$ \\
\hline $\begin{array}{l}\text { Sollicitanten beschikken } \\
\text { niet over juiste } \\
\text { competenties }\end{array}$ & $87 \%$ & $35 \%$ & $20 \%$ & $33 \%$ & $13 \%$ \\
\hline $\begin{array}{l}\text { Te hoge salariseisen } \\
\text { sollicitanten }\end{array}$ & $92 \%$ & $36 \%$ & $30 \%$ & $66 \%$ & $23 \%$ \\
\hline
\end{tabular}

Bron: ROA, Arbeidsmarktmonitor Metalektro, 2014

Noot: De dikgedrukte percentages geven aan bij welke genoemde oorzaak een bepaald gevolg relatief het vaakst genoemd wordt. Bedrijven konden meerdere oorzaken en gevolgen van nietingevulde vacatures tegelijkertijd kiezen. De percentages tellen daardoor niet op tot $100 \%$. Alleen oorzaken en gevolgen die in de top vijf voorkomen van oorzaken en gevolgen voorkomen zijn opgenomen in de tabel.

Het is duidelijk dat een toename van de werkdruk het vaakst genoemde gevolg is, ongeacht de oorzaak van de vacature. Dit gevolg wordt echter het vaakst genoemd als er sprake is van een gebrek aan sollicitanten voor de vacature. Het blijven liggen van werk of het missen van deadlines wordt vaak als gevolg genoemd bij vacatures waar de sollicitanten over onvoldoende werkervaring beschikken. Wellicht is dit het geval omdat anders een minder ervaren en dus waarschijnlijk minder productieve werknemer in dienst moet worden genomen. Minder mogelijkheden om te innoveren wordt vaker als gevolg genoemd bij vacatures waarvoor de sollicitanten te hoge salariseisen stellen. Hoewel we dit niet kunnen toetsen met de beschikbare gegevens, is het niet ondenkbaar dat juist technici in functies waar innovatie centraal staat soms hogere salariseisen stellen. 


\subsection{Aanpassingen in werving en selectie om moeilijk vervulbare vacatures op te vullen}

Welke aanpassingen in werving en selectie bedrijven het meeste doorvoeren om met moeilijk vervulbare vacatures voor technici om te gaan en in welke mate deze veranderingen als effectief worden beschouwd, is af te lezen uit Figuur 3.14. Op de horizontale as is te zien welk percentage bedrijven een bepaalde aanpassing toepast. Op de verticale as is te zien welk percentage van de bedrijven die een bepaalde aanpassing toepassen dit als (zeer) effectief beschouwt. De trendlijn in de figuur toont een positief verband tussen de mate waarin maatregelen worden toegepast en de mate waarin deze als (zeer) effectief worden beschouwd.

FIGUUR 3.14 Aanpassingen in werving en selectie om met moeilijk vervulbare vacatures voor technici om te gaan (\% bedrijven), 2014

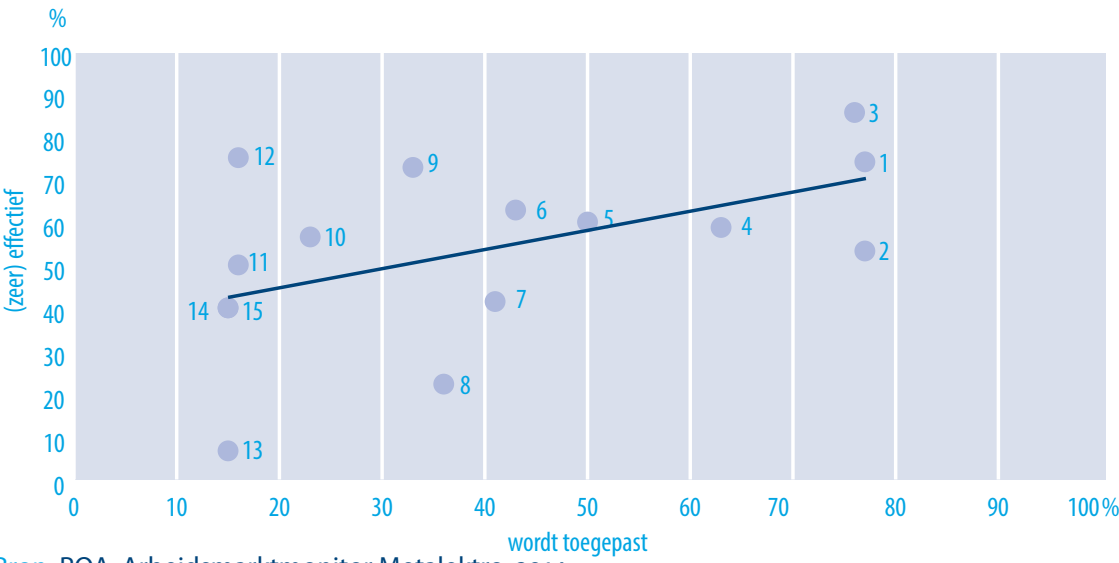

Bron: ROA, Arbeidsmarktmonitor Metalektro, 2014

Noot: 1. Bieden van goede loopbaanperspectieven

2. Aantrekken van mensen met minder ervaring

3. Inschakelen uitzendbureaus, commerciële werving- en selectiebureaus of detacheringsbureaus

4. Competentiegericht werven

5. Actiever benaderen van scholieren

6. Aantrekken van anders opgeleiden (andere richting)

7. Wervingsbonus voor het eigen personeel

8. Inschakelen UWV WERKbedrijf (voormalig: CWI)

9. Werven in het buitenland

10. Collegiaal inlenen van personeel

11. Inschakelen bureau voor arbeidsmarktcommunicatie

12. Bieden van betere, CAO-overstijgende arbeidsvoorwaarden

13. Actiever benaderen van gedeeltelijk arbeidsongeschikten

14. Bieden van hoger salaris

15. Aantrekken van lager opgeleiden (lager niveau) 
De drie aanpassingen in werving en selectie die het meest zijn toegepast in 2014 zijn het bieden van goede loopbaanperspectieven, het inschakelen van uitzendbureaus, commerciële werving- en selectiebureaus of detacheringsbureaus en het aantrekken van mensen met minder ervaring. Al deze aanpassingen worden door bijna vier op de vijf bedrijven toegepast. De eerste twee worden bovendien door $86 \%$ en $77 \%$ van de bedrijven die ze toepassen als (zeer) effectief beschouwd. Voor het aantrekken van mensen met minder ervaring ligt dit percentage lager met een score die ongeveer gelijk is aan de gemiddelde effectiviteit van alle aanpassingen samen (53\%). Als we deze drie meest toegepaste aanpassingen vergelijken met 2013 blijkt dat zowel het bieden van goede loopbaanperspectieven als het aantrekken van mensen met minder ervaring, minder zijn toegepast alsook minder effectief werden bevonden dan in 2013. Het inschakelen van externe bureaus werd ook minder vaak toegepast in 2014 maar werd wel effectiever gevonden dan in 2014.

Aanpassingen die, naast de drie meest genoemde aanpassingen, ook ieder door minimaal de helft van de bedrijven werden toegepast in 2014 zijn het competentiegericht werven en het actiever benaderen van scholieren. Beiden scoren daarnaast qua effectiviteit rond de $60 \%$. Ten opzichte van 2013 steeg het aantal bedrijven dat gebruik maakte van competentiegericht werven aanzienlijk, namelijk van $43 \%$ naar $63 \%$. Nadat deze maatregel al jarenlang hoog scoorde op effectiviteit, maar tot dusverre door relatief weinig bedrijven werd toegepast, zijn bedrijven dus met ingang van 2014 steeds meer gebruik hiervan gaan maken.

Voor de nog niet genoemde aanpassingen geldt dat deze ieder door minder dan de helft van de bedrijven werden toegepast. Toch zitten hier enkele maatregelen tussen die een hoge mate van effectiviteit kennen, maar waarschijnlijk duurder of minder makkelijk uitvoerbaar zijn voor de meeste bedrijven en daardoor relatief weinig benut worden. De meest in het oog springende voorbeelden hiervan zijn het bieden van betere, CAO-overstijgende arbeidsvoorwaarden en het werven in het buitenland. Andere maatregelen die vaak als relatief effectief worden ervaren, maar verhoudingsgewijs weinig worden toegepast zijn het collegiaal inlenen van personeel en het aantrekken van anders opgeleiden. Een maatregel die weinig gebruikt wordt en ook relatief laag scoort op effectiviteit is het bieden van een hoger salaris. Toch hebben metalektrobedrijven hiermee wel eens te maken, zoals Tekstbox 3.4 illustreert. 
Herman van der Donk, HR-manager bij Ardagh in Deventer, geeft aan dat het voor grote bedrijven soms lastig concurreren is met kleinere bedrijven als het gaat om het werven van technici in een functiecategorie die gekenmerkt wordt door schaarste. Kleinere ondernemingen kunnen volgens hem namelijk betrekkelijk gemakkelijk schaarse technici bij grote bedrijven 'wegkapen' door het aanbieden van een veel hoger loon. Aangezien kleinere bedrijven doorgaans maar een kleine groep technici met een bepaalde achtergrond nodig hebben, terwijl het bij grote bedrijven al snel om een grote groep technici met die achtergrond gaat, betekent concurreren op basis van het loon voor kleine bedrijven doorgaans dat zij slechts een kleine groep werknemers een loonsverhoging hoeven te geven, terwijl grote bedrijven al snel voor een (te) grote groep een dergelijke loonsverhoging moeten doorvoeren: "Concurreren op loon is daardoor al snel onhaalbaar voor grotere bedrijven als Ardagh, wat betekent dat grotere bedrijven zoals wij er baat bij hebben als het totale aanbod van kwalitatief hoogwaardige technici groot genoeg is. Het belang dat Ardagh heeft bij een voldoende aanbod van kwalitatief hoogwaardige technici op macroschaal is een belangrijke reden waarom binnen Ardagh de opleidingstaak heel serieus wordt genomen. Zo zet het bedrijf volgens Van der Donk sterk in op het opleiden van jongeren via BBL-trajecten en is het voor Ardagh geen bezwaar dat van de ongeveer 5 BBL-leerlingen die Ardagh per jaar opleidt, er doorgaans 1 of 2 aan het einde van hun opleiding niet bij Ardagh maar bij een ander bedrijf gaan werken. “0p die manier is er voldoende aanbod voor zowel kleinere als grotere bedrijven en is het wegkapen van personeel bij de concurrent niet meer noodzakelijk", stelt Van der Donk.

\subsection{Interne aanpassingen om moeilijk vervulbare vacatures op te vullen}

Naast het doorvoeren van veranderingen in werving en selectie kunnen bedrijven er ook voor kiezen om via aanpassingen in de interne bedrijfsvoering een oplossing te vinden voor moeilijk vervulbare vacatures. Figuur 3.15 toont wederom hoeveel procent van de bedrijven met wervingsproblemen gebruik maakt van bepaalde aanpassingen (horizontale as) en zet dit af tegen het percentage bedrijven dat deze maatregel als (zeer) effectief beschouwt (verticale as). Evenals in 2013 en 2012 zijn de vier meest toegepaste interne veranderingen het flexibeler inzetten van huidige werknemers, overwerken, om- of bijscholen van het huidig personeel en het anders organiseren van werk. Het percentage bedrijven dat deze maatregelen in 2014 heeft toegepast verschilt nauwelijks van de percentages in 2013. Zorgwekkend blijft het feit dat overwerk al jaren hoog scoort op zowel het aandeel bedrijven dat deze maatregel toepast als het percentage bedrijven dat overwerken als (zeer) effectief beschouwt. Hoewel overwerk op korte termijn een gemakkelijk in te zetten middel is om met moeilijk vervulbare vacatures om te gaan, zijn er duidelijk aanwijsbare negatieve gevolgen voor de duurzame inzetbaarheid van werknemers. Zo weten we dat het maken van veel overuren op termijn negatieve consequenties kan hebben voor onder meer de baantevredenheid en gezondheid. ${ }^{6}$ Tevens blijken

6 Ook voor het draaien van een gematigd aantal overuren geldt dat dit samenhangt met een toegenomen risico op mentale problemen, zie bijvoorbeeld Kleppe e.a. (2008) Working Overtime is Associated With Anxiety and Depression: The Hordaland Health Study, Journal of Occupational \& Environmental Medicine, Vol. 50(6): 658-666. 
werknemers die meer overuren draaien gemiddeld genomen eerder met pensioen te gaan en sneller te wisselen van werkgever. ${ }^{7}$ Werkgevers doen er dus verstandig aan om, in het kader van de duurzame inzetbaarheid van werknemers, de mate waarin werknemers overuren draaien binnen de perken te houden.

FIGUUR 3.15 Interne aanpassingen om met moeilijk vervulbare vacatures voor technici om te gaan (\% bedrijven), 2014

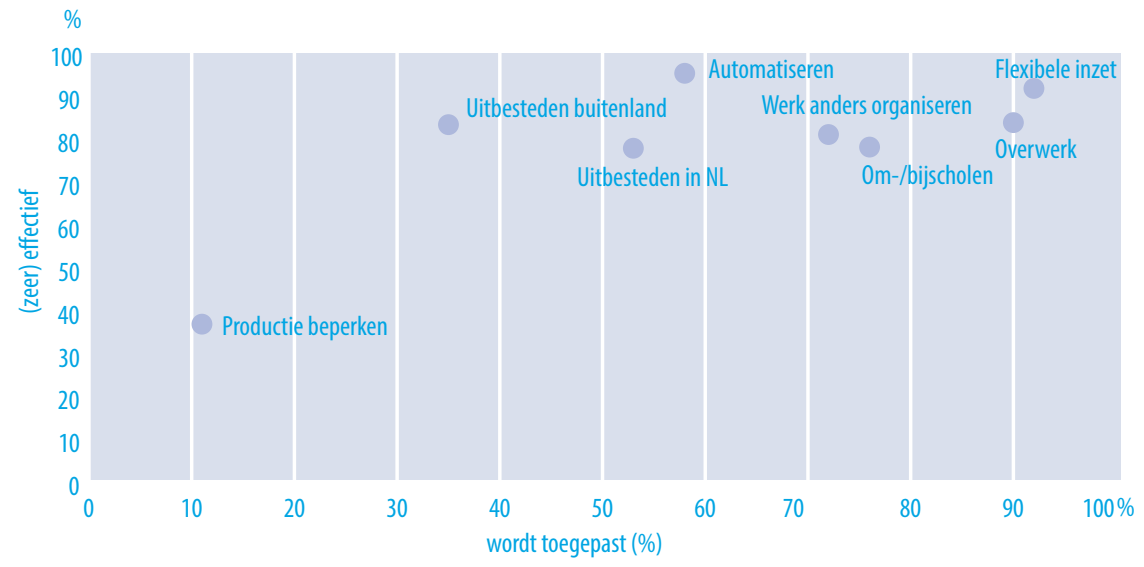

Bron: ROA, Arbeidsmarktmonitor Metalektro, 2014

Automatiseren staat zowel qua gebruik als effectiviteit op dezelfde positie als in 2013. Uitbesteden aan het buitenland steeg daarentegen zowel in gebruik als effectiviteit, terwijl het uitbesteden binnen Nederland juist daalde op beide dimensies. Het beperken van de productie werd weliswaar vaker toegepast dan in 2013, maar staat - waarschijnlijk vanwege de ingrijpende aard van deze maatregel - nog steeds onderaan de lijst van meest toegepaste instrumenten. Ook werd deze maatregel als veel minder effectief ervaren in 2014 dan in 2013 (33\% versus 67\%). In eerste instantie lijkt er in Figuur 3.15 een positief verband te zijn tussen de mate waarin een bepaalde maatregel wordt toegepast en de mate waarin deze maatregel als (zeer) effectief wordt beschouwd. Als we het beperken van de productie echter buiten beschouwing laten verdwijnt dit positieve verband. Dit is voornamelijk het gevolg van het feit dat geen enkele van de overige interne aanpassing lager scoort dan $77 \%$ op effectiviteit. Dit impliceert dat interne aanpassingen gemiddeld veel beter scoren op effectiviteit dan aanpassingen in werving en selectie.

$7 \quad$ Zie bijvoorbeeld Van den Berg e.a. (2010) Influence of Health and Work on Early Retirement, Journal of Occupational \& Environmental Medicine, Vol. 52(6): 576-583. 


\section{4 \\ COMPETENTIES \\ EN OPLEIDINGSINSPANNINGEN}

In 2014 stegen de gemiddelde opleidingsuitgaven voor technische medewerkers weer voor het eerst sinds 2009. Ook het gemiddeld aantal dagen training per werknemer steeg in 2014. De stijgende uitgaven aan opleiding en training zien we op vrijwel alle trainingsgebieden terug. De toename is het grootst voor trainingen in veilig gedrag en trainingen in communicatieve vaardigheden. Overigens is de stijging in de trainingsdeelname bijzonder sterk bij de medewerkers in de flexibele schil. Het initiatief voor trainingen werd zoals in voorgaande jaren in de meeste gevallen genomen door de leidinggevende en werknemer samen, maar het belang van HR bij het initiëren van trainingen en cursussen neemt toe. Om technici te betrekken bij hun eigen ontwikkeling onderneemt een grote meerderheid van de bedrijven actie. In de meeste gevallen wordt hiertoe in functioneringsgesprekken aandacht besteed aan opleiding en ontwikkeling. 


\subsection{4 brengt definitief einde aan daling in opleidingsuitgaven}

Figuur 4.1 geeft inzicht in de ontwikkeling van de totale opleidingsuitgaven voor technische werknemers in de Metalektro, als percentage van de loonsom. De belangrijkste conclusie hieruit is dat de gemiddelde opleidingsuitgaven in 2014 voor het eerst sinds 2009 weer zijn gestegen (van 1,3 naar 1,6\%). Figuur 4.1 geeft naast de opleidingsuitgaven inzicht in de ontwikkeling van de omzet in de sector in dezelfde periode. Door deze twee factoren tegen elkaar af te zetten ontstaat het beeld dat bedrijven met enige vertraging (van plusminus één jaar), hun opleidingsuitgaven aanpassen aan het economisch vaarwater van de sector. Dit wordt bevestigd door bedrijven uit de sector, die aangeven dat men in minder florisante tijden vanwege cash-flow redenen de trainingsinspanningen verschuift van formeel naar informeel leren, wat met minder out-of-pocket kosten gepaard gaat. Het bijhouden van belangrijke vakinhoudelijke ontwikkelingen gaat hiermee gewoon door, maar er wordt dan wel minder opgeleid voor bepaalde diploma's (zoals bijvoorbeeld de upgrading van $\mathrm{MBO}$ naar $\mathrm{HBO}$ niveau).

FIGUUR 4.1 Gemiddelde totale opleidingsuitgaven voor technische werknemers per bedrijf (gemiddeld \% van loonsom) en indexcijfer omzet Metalektro, 2006-2014

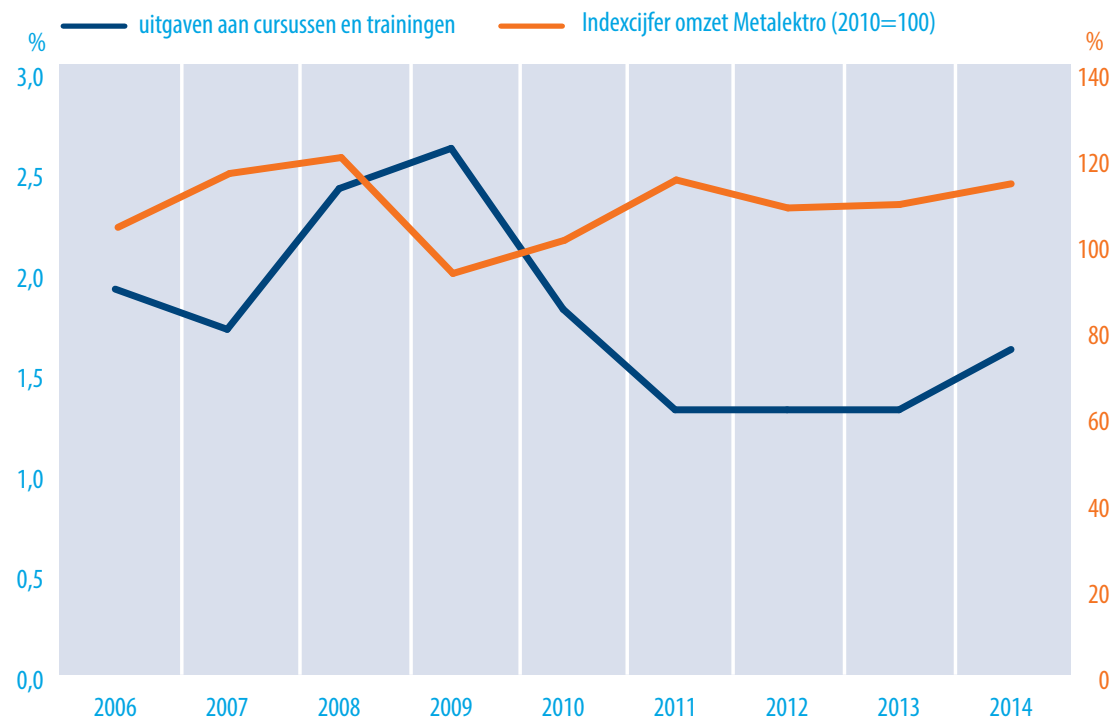

Bron: ROA, Arbeidsmarktmonitor Metalektro, 2006-2014 en ROA berekening o.b.v. CBS gegevens

Zo ging de groeiende omzet binnen de sector tussen 2006 en 2008 vergezeld van stijgende investeringen in opleidingsinspanningen tot in 2009. Na de daling in de omzet in 2009 zakten ook de uitgaven aan cursussen en trainingen snel in. De groeiende omzet in 2009-2011 zorgde echter niet meteen voor een hernieuwde toename in opleidingsuitgaven, maar ging tot 2014 gepaard met een stabilisering van de scholingsuitgaven op 
een bijzonder laag percentage van 1,3 procent. Er zijn verschillende mogelijke verklaringen voor het uitblijven van een stijging in de scholingsuitgaven in 2011:

1) in de periode 2011-2013 groeide de flexibele schil sterk. In personeel met een flexibel dienstverband wordt in de regel minder geïnvesteerd dan in personeel met een vast contract. Pas nu in de tweede helft van 2014 de flexibele schil weer iets is afgenomen (en het aandeel medewerkers in vaste dienst is gegroeid, zie Hoofdstuk 2) zijn de opleidingsuitgaven weer gestegen.

2) Metalektrobedrijven bleven langdurig pessimistisch na de economische neergang vanaf 2008 en zijn daardoor - ondanks de stijgende omzetgroei van 2010 en 2011 - voorzichtig geweest om hun uitgaven en investeringen al te snel te verhogen. Hierdoor namen uitgaven aan trainingen pas in 2014, met sterke vertraging, toe.

\subsection{Aantal dagen besteed aan opleiding ook gestegen}

Naast de uitgaven aan cursussen en trainingen, steeg in 2014 ook het aantal werkdagen dat gemiddeld per technische werknemer werd besteed aan opleiding. Waar in $2013 \mathrm{nog}$ gemiddeld 2,5 dagen per technische werknemer werden besteed aan cursussen en trainingen, nam dit met bijna één dag toe tot gemiddeld 3,4 dagen in 2014.

\section{Sterke stijging trainingsdeelname in de flexibele schil}

Een interessante ontwikkeling doet zich voor in de trainingsdeelname van de verschillende typen dienstverbanden. Figuur 4.2 toont per type dienstverband het percentage technici dat minimaal één cursus of training heeft gevolgd. Dit percentage is in 2014 verder toegenomen voor zowel medewerkers in tijdelijk dienstverband ( $45 \%$ in 2014) als voor ingeleend personeel (29\% in 2014), maar niet voor personeel in vast dienstverband (49\% in 2014). ${ }^{8}$ Dit suggereert dat de toename in opleidingsinspanningen vooral gericht is op de flexibele schil. Werknemers in vast dienstverband en in de flexibele schil worden dus steeds 'gelijker' in termen van cursus- en trainingsdeelname. Nog altijd geldt echter dat werknemers in vaste dienst iets vaker worden getraind dan werknemers in tijdelijke dienst en dat laatstgenoemden op hun beurt weer vaker deelnemen aan trainingen dan ingeleende werknemers.

8 Sinds 2013 is in de vragenlijst gebruikt gemaakt van een schuifbalk (in plaats van een invulvak) waarmee respondenten op een schaal van o tot 100 kunnen aangeven hoeveel procent van hun technisch personeel met een specifiek dienstverband minimaal één cursus heeft gevolgd. In theorie is het mogelijk dat deze wijziging (een deel van) de sprong tussen 2012 en 2013 verklaart. Echter, het percentage bij de categorie'vast dienstverband' kent geen sprong, terwijl ook daar de schuifbalk is geïntroduceerd. Dit wijst erop dat er wel degelijk sprake is van een sterke stijging in onderliggende trainingsdeelname van flexibele medewerkers. 
FIGUUR 4.2 Gemiddelde training- en cursusdeelname van technisch personeel (\% medewerkers naar type dienstverband), 2010-2014

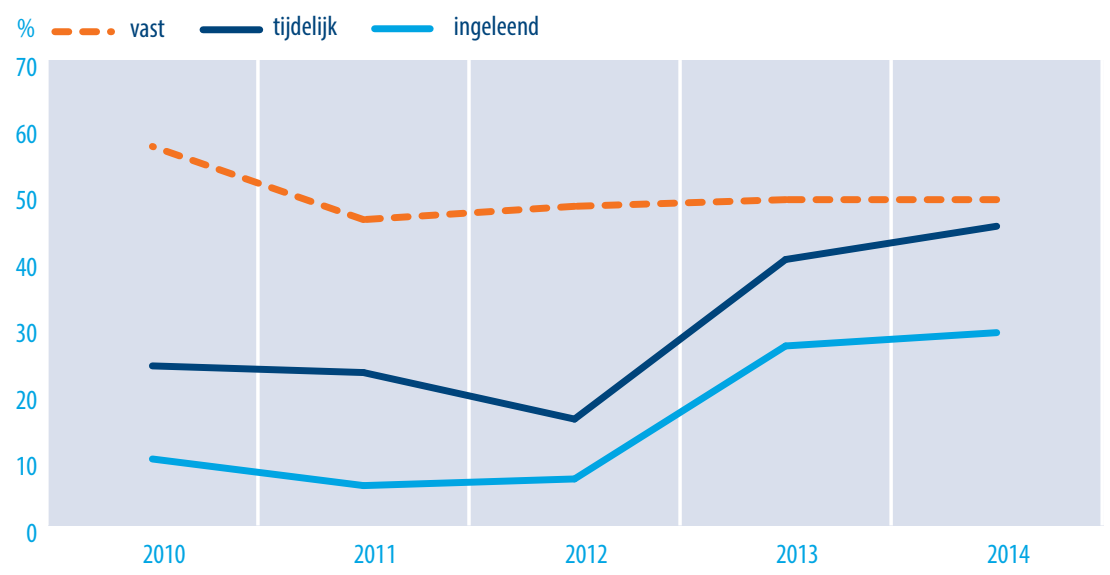

Bron: ROA, Arbeidsmarktmonitor Metalektro, 2010-2014

\subsection{Initiatief voor trainingen en stimuleren van betrokkenheid personeel}

Figuur 4.3 toont voor 2012 tot en met 2014 vanuit wie volgens de metalektrobedrijven doorgaans het initiatief kwam voor cursussen en trainingen voor het technische personeel. In alle drie de jaren werd in de meeste gevallen gezamenlijk (leidinggevende + werknemer) het initiatief voor scholing genomen. Dit aandeel werd bovendien elk jaar 2 procentpunt groter. Direct leidinggevenden zijn steeds minder vaak initiatiefnemer van scholing en training van technisch personeel. In 2014 daalde dit zelfs 9 procentpunten ten opzichte van 2013, van 31 tot $22 \%$. Het belang van de afdeling HR bij het initiëren van trainingen en cursussen voor het technisch personeel lijkt te zijn toegenomen, getuige de stijging van 12\% naar 18\% van het totale aantal trainingen tussen 2013 en 2014. Dit houdt volgens signalen uit de sector verband met de toegenomen planmatige aanpak van het opleidings- en trainingsbeleid van bedrijven en een toenemend gebruik van bedrijfsopleidingsplannen in plaats van persoonlijke opleidingsplannen (zie ook Figuur 4.7). 


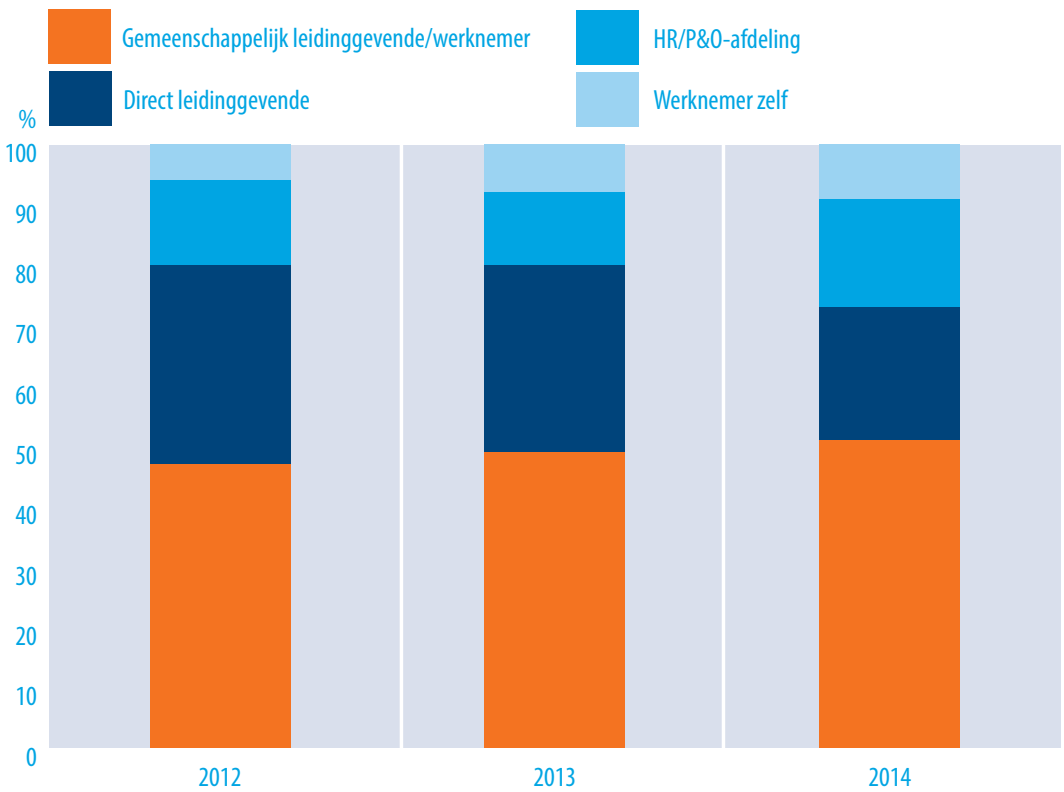

Bron: ROA, Arbeidsmarktmonitor Metalektro, 2012-2014

\section{Betrokkenheid technisch personeel bij eigen opleiding en ontwikkeling}

Het merendeel van de bedrijven heeft in 2014 actie ondernomen om de betrokkenheid van technici bij hun eigen ontwikkeling te stimuleren. Slechts in $12 \%$ van de metalektrobedrijven is in 2014 niets gedaan op dit gebied (zie Figuur 4.4). 88\% van de bedrijven heeft dus op één of meerdere manieren getracht de betrokkenheid van technisch personeel bij de eigen opleiding en ontwikkeling te stimuleren. De meest gebruikte manier hierbij is het besteden van meer aandacht aan opleiding en ontwikkeling in een functioneringsgesprek. Zeven van de tien metalektrobedrijven deden dit in 2014. Een andere vaak genoemde stimulans is dat aan leidinggevenden wordt geleerd om coachend leiding te geven (36\%). Hoewel dit nog steeds op de tweede plaats staat, is deze stimulans door iets minder bedrijven toegepast dan vorig jaar (een daling van $14 \%$-punten). Een activiteit die in 2014 juist vaker is gebruikt dan in 2013 is het creëren van een leerrijke werkomgeving. Dit werd in 2014 door 26\% van de bedrijven toegepast, tegen 17\% in 2013. Andere activiteiten welke door een kwart tot een derde van de bedrijven zijn ondernomen - met als doel de betrokkenheid van het technisch personeel bij de eigen opleiding en ontwikkeling te vergroten - zijn stimuleren dat werknemers elkaar enthousiast maken voor opleiding en ontwikkeling (32\%), het aanbieden van een persoonlijk ontwikkelingsplan (29\%) en extra inspanningen vanuit P\&O (27\%). Over het algemeen geldt voor deze activiteiten dat ze vaker worden ontplooid binnen grote bedrijven dan bij het MKB. Zo zien we significante verschillen tussen grote en midden- en kleinbedrijven in het aandeel dat activiteiten onderneemt om een leerrijke omgeving te creëren (de helft van de grote 
bedrijven versus een kwart van de kleine bedrijven) en in het aandeel dat in het bedrijfsblad aandacht besteed aan opleiding en ontwikkeling ( $45 \%$ van de grote bedrijven en $10 \%$ van de MKB bedrijven). Dit is volgens verschillende bedrijven een logisch gevolg van de grotere aandacht voor Human Resource Development bij de bedrijfsleiding van grotere bedrijven.

FIGUUR 4.4 Activiteiten ter stimulering betrokkenheid technisch personeel bij eigen opleiding en ontwikkeling (\% bedrijven), 2014

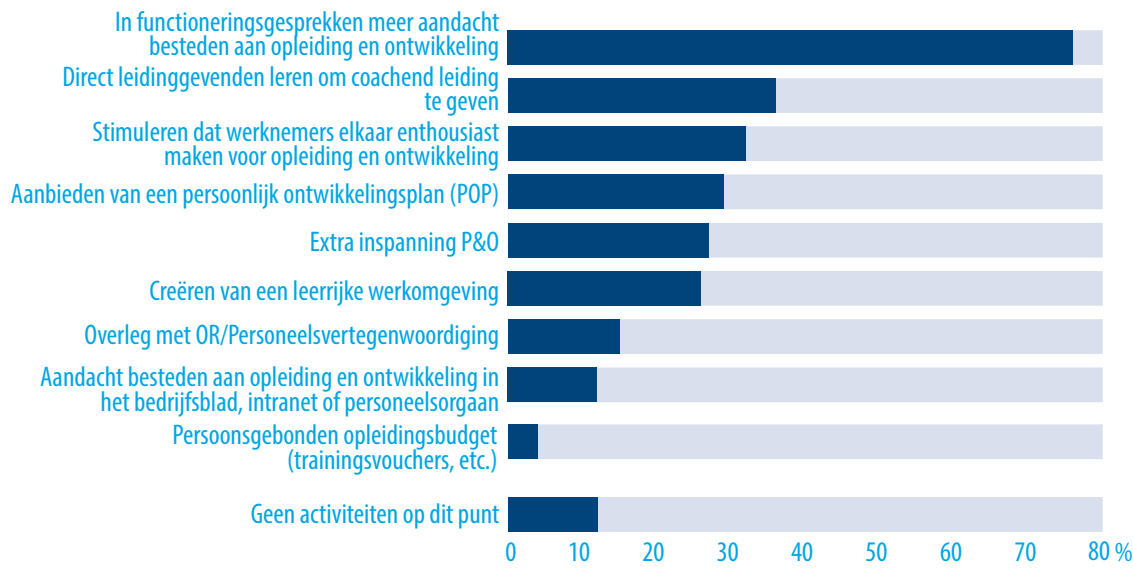

Bron: ROA, Arbeidsmarktmonitor Metalektro, 2014

TEKSTBOX 4.1 Scholing belangrijk, ongeacht leeftijd

Miedema, producent van landbouwwerktuigen, investeert naar eigen zeggen veel in scholing. Het scholings- en trainingsbeleid van Miedema is echter niet in een vaste structuur gegoten en komt op een informele manier tot stand, aldus managing director René Boeijenga. Over het algemeen wordt de scholing en training van medewerkers persoonlijk afgestemd tussen het bedrijf en de werknemers. Deze informele structuur past bij de platte organisatiestructuur van Miedema, maar er schuilt volgens Boeijenga ook een potentieel gevaar in: niet elke werknemer is even mondig en deze informele structuur zou er in theorie toe kunnen leiden dat minder mondige medewerkers minder scholing ontvangen dan hun mondigere collega's.

Bij Miedema wordt op het gebied van scholing en training geen onderscheid gemaakt op basis van leeftijd. Of iemand nu 25 of 45 is, over het algemeen komt iedereen in aanraking voor extra scholing. Dit heeft als voordeel dat een lasser van bijvoorbeeld 45 ook aan bijscholing kan doen en wellicht op deze manier een overstap kan maken naar minder fysiek belastend werk (het bedienen van een machine bijvoorbeeld). Een oudere lasser die bijvoorbeeld nog een nieuwe lasrobot wil leren bedienen heeft Boeijenga graag binnen zijn bedrijf, aangezien deze persoon duidelijk gemotiveerd is, vaak een laag ziekteverzuim heeft en gezien zijn jarenlange ervaring een mentorrol zou kunnen vervullen voor jonge lassers. 


\subsection{Meeste trainingen vaktechnisch, sterke toename in veiligheidstrainingen}

Met de kennis dat metalektrobedrijven in 2014 meer dan in de crisisjaren investeerden in trainingen voor hun technisch personeel, is het interessant om na te gaan op welke terreinen deze trainingen zich afspeelden. Hierin heeft mogelijk een verschuiving plaatsgevonden. Figuur 4.5 geeft een overzicht van de terreinen waarop technisch personeel in 2014 is getraind. Het eerste wat opvalt is dat voor bijna alle trainingsgebieden een (lichte) toename te zien was in 2014 ten opzichte van 2013. De stijgende uitgaven aan opleiding en training die we in Figuur 4.1 zagen, zien we dus over bijna de hele linie van trainingsgebieden terug. De sterkste toename ten opzichte van 2013 zien we terug voor wat betreft veilig gedrag (+15\%-punt) en communicatieve vaardigheden $(+11 \%$ punt). Als we naar alleen naar 2014 kijken, dan zien we dat trainingen op het gebied van vaktechnische vaardigheden nog altijd op de eerste plaats staan. In bijna $90 \%$ van de metalektrobedrijven worden werknemers getraind in vaktechnische vaardigheden. Ook de deelname aan BHV/EHBO-cursussen scoort hoog; 82\% van de bedrijven gaf aan dat hun personeel op dat gebied werd getraind in 2014. Voorts is er nog binnen een noemenswaardig aandeel van de metalektrobedrijven getraind op veilig gedrag (39\%) en op het gebied van leidinggeven (34\%). Op de vijfde plaats staan trainingen in communicatieve vaardigheden; in $30 \%$ van de bedrijven volgde één of meerdere medewerkers een training op dat gebied.

FIGUUR 4.5 Terreinen waarop technisch personeel is getraind (\% bedrijven), 2013-2014

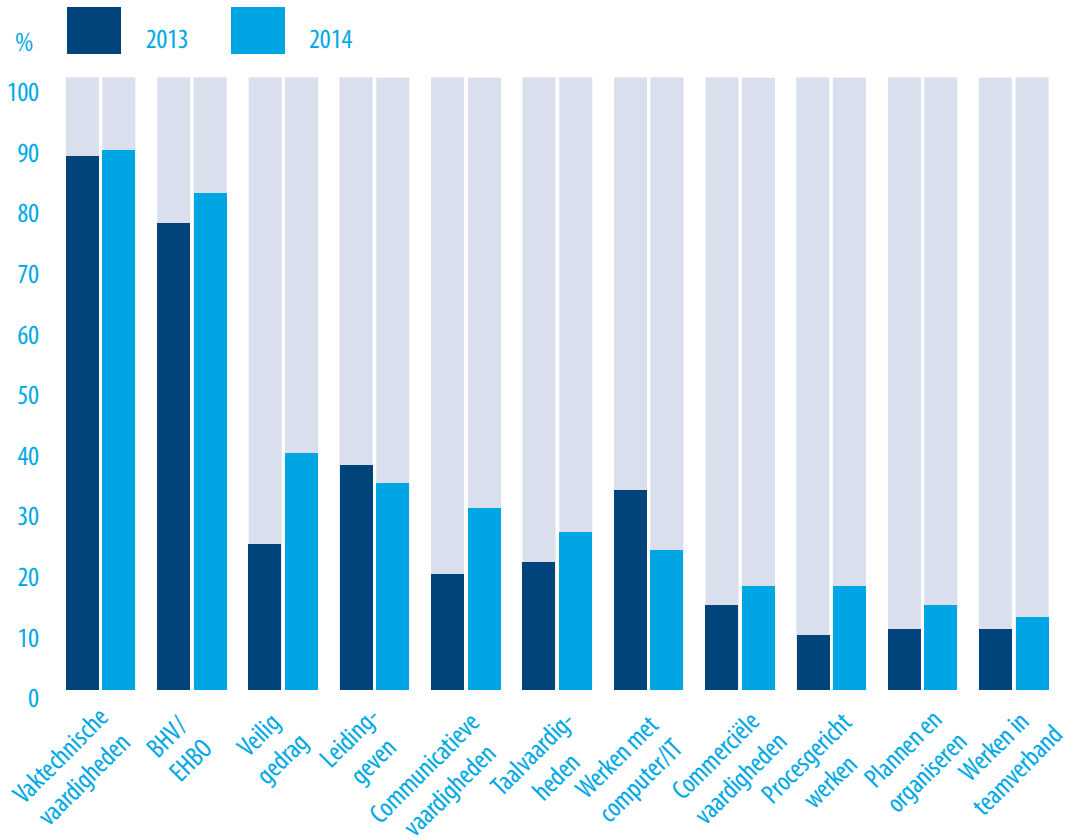

Bron: ROA, Arbeidsmarktmonitor Metalektro, 2013-2014 


\section{Cursussen/trainingen vooral gericht op de huidige functie}

De cursusdeelname van het technisch personeel was - gemiddeld genomen over alle bedrijven heen - in 79\% van de gevallen primair gericht op de huidige functie van het personeel. Gemiddeld genomen waren verder twee van de tien cursussen gericht op de verdere loopbaan binnen het eigen bedrijf. Het aandeel cursussen dat gericht was op de verdere loopbaan buiten het eigen bedrijf bedroeg gemiddeld genomen slechts $2 \%$. Voor grote bedrijven ligt dit percentage (significant) hoger (4\%), maar is dit aandeel evengoed klein. Dit neemt niet weg dat cursussen en trainingen die primair zijn gericht op de eigen functie of een andere functie binnen het bedrijf, vaak vaktechnisch van aard, evengoed de employability en dus ook de potentiële externe mobiliteit van werknemers vergroten.

\subsection{Helft van de bedrijven ervaart (geen) belemmeringen bij scholing technisch personeel}

De helft van de bedrijven gaf aan in 2014 geen belemmeringen te hebben ervaren bij de scholing van hun technisch personeel. Dit betekent automatisch dat de andere helft van de bedrijven wél te maken heeft gehad met belemmerende factoren. Figuur 4.6 zet een breed scala aan factoren op een rij die de scholing van technisch personeel mogelijk belemmeren. Tijd speelt het vaakst een rol en wordt door drie op de tien bedrijven genoemd als belemmering. Een puur financiële factor ('cursussen kosten veel geld') wordt door twee op de tien metalektrobedrijven genoemd als zijnde een belemmering. Naast deze twee factoren worden ook belemmeringen aan de kant van de werknemer aangewezen. Zo geeft een klein deel van de bedrijven aan dat het technisch personeel de scholingswensen niet uit naar het management (14\%) of dat het technisch personeel niet geïnteresseerd is in cursussen (14\%). 
FIGUUR 4.6 Belemmeringen bij scholing technisch personeel (\% bedrijven), 2014

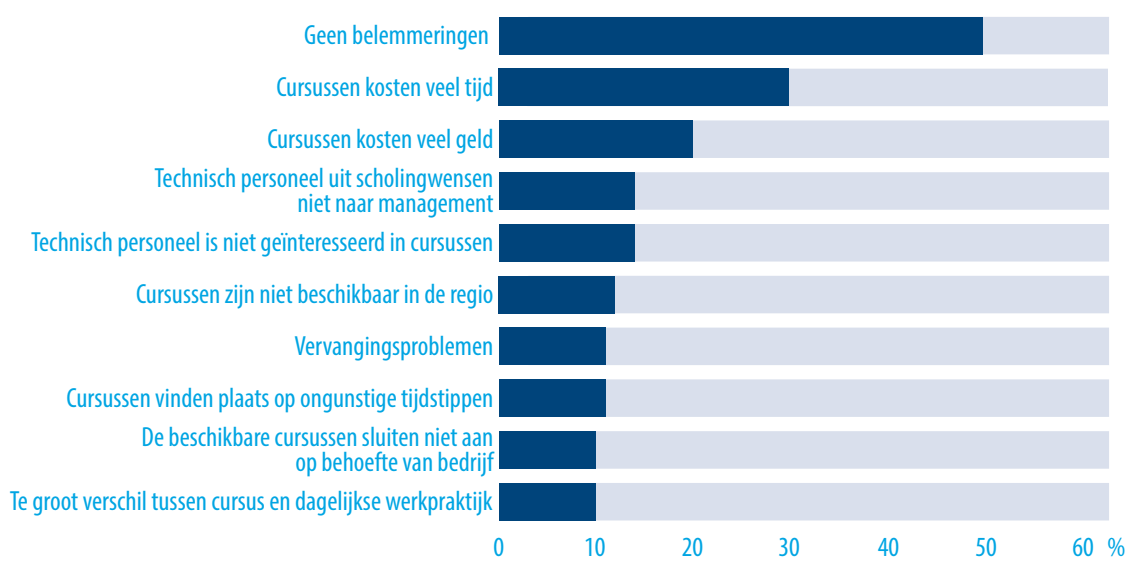

Bron: ROA, Arbeidsmarktmonitor Metalektro, 2014

Noot: Alleen de belemmeringen die door tenminste $10 \%$ van de werkgevers werden genoemd zijn opgenomen in de figuur.

\subsection{Gebruik HR-instrumenten in 2014}

Om het loopbaanmanagement van medewerkers in goede banen te leiden maken metalektrobedrijven gebruik van diverse HR-instrumenten. Deze HR-instrumenten worden onderverdeeld in vier bredere categorieën welke samen de loopbaanmanagementcyclus vormen:

(A) De bepaling van het huidige competentieniveau van het technisch personeel (assessment).

(B) Het vastleggen van doelen en acties.

(C) Het volgen van schooling.

(D) Het opdoen van de gewenste werkervaring.

Figuur 4.7 geeft deze verschillende categorieën weer inclusief de daarbij horende HR-instrumenten die bedrijven kunnen inzetten ten behoeve van de ontwikkeling van hun (technisch) personeel. Daarnaast worden in de figuur nog twee algemenere HR-instrumenten weergegeven die breder toepasbaar zijn. Loopbaanplanning en werkoverleggen kunnen in de praktijk namelijk doorlopend worden ingezet ter ondersteuning van alle vier onderscheiden categorieën van het loopbaanmanagement. De figuur geeft een overzicht van de in 2014 toegepaste HR-instrumenten en vergelijkt dit met 2013. Loopbaanplanning wordt relatief weinig ingezet door metalektrobedrijven - of in ieder geval niet vaak voor de meerderheid van het technisch personeel. Het werkoverleg werd daarentegen wel door een ruime meerderheid van bedrijven (86\%) ingezet voor het leeuwendeel van hun technici. Dit is een lichte toename ten opzichte van het jaar ervoor; toen bedroeg dit aandeel minder dan acht op de tien bedrijven. 
FIGUUR 4.7 HR-instrumenten die zijn ingezet voor de meerderheid van het technisch personeel (\% bedrijven), 2013-2014

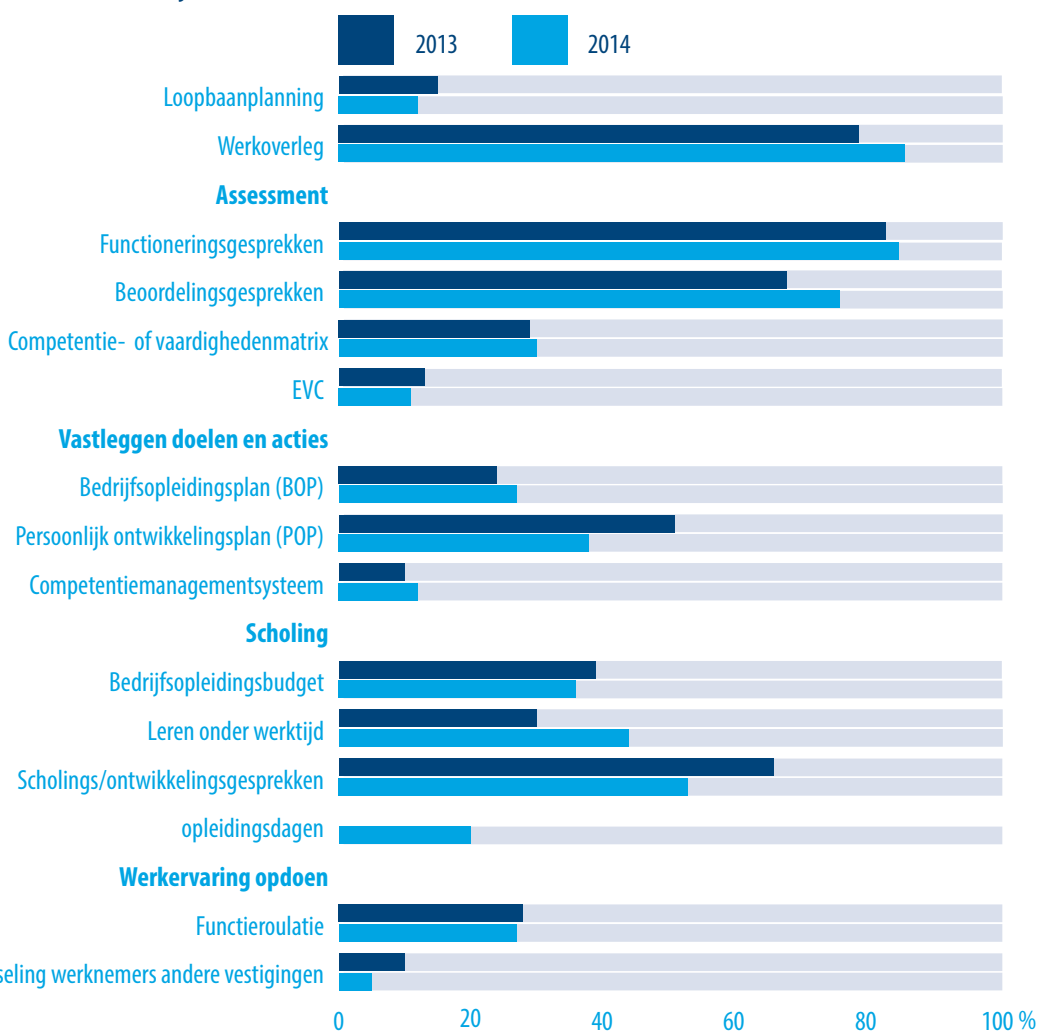

Bron: ROA, Arbeidsmarktmonitor Metalektro, 2013-2014

Noot: Het instrument 'opleidingsdagen' is in 2014 nieuw opgenomen als antwoordcategorie, waardoor observatie voor 2013 ontbreekt.

\section{(A) Assessment}

Voor het vaststellen van het huidige competentieniveau van het technisch personeel blijkt vooral een beroep te worden gedaan op functionerings- en beoordelingsgesprekken. Functioneringsgesprekken worden door $85 \%$ van de bedrijven in de Metalektro ingezet voor een meerderheid van het technisch personeel en beoordelingsgesprekken door ruim driekwart van de bedrijven. Beoordelingsgesprekken werden ingezet door iets meer bedrijven dan voorheen: dit aandeel is met 8 procentpunten gestegen ten opzichte van 2013. De competentie- of vaardighedenmatrix en het ervaringscertificaat (EVC) worden aanzienlijk minder vaak ingezet voor de meerderheid van de technici. De EVC wordt slechts door één op de tien bedrijven aangevinkt en de competenties- of vaardighedenmatrix door iets meer bedrijven, te weten drie op de tien. Het gebruik van dit laatstgenoemde instrument lijkt samen te hangen met de bedrijfsomvang: $27 \%$ van de midden- en kleinbedrijven stelden competentie-matrices op voor de meerderheid 
van het technisch personeel, terwijl dit aandeel voor grote bedrijven ( $>250$ werknemers) één op twee bedroeg. Dat het in kaart brengen van competenties van medewerkers ook voor een MKB-bedrijf heel goed uitvoerbaar is, wordt in Tekstbox 4.2 geïllustreerd aan de hand van een praktijkvoorbeeld.

\section{(B) Vastleggen van doelen en acties}

Het vastleggen van doelen en acties draagt er tijdens het loopbaanmanagement toe bij dat er achteraf geen misverstanden kunnen bestaan over de afspraken die werkgever en werknemer overeen komen. 38\% van alle bedrijven maakte in 2014 bij een meerderheid van het technisch personeel gebruik van een persoonlijk ontwikkelingsplan (POP) om doelen en acties vast te leggen. Dit is een stevige daling ten opzichte van 2013. In dat jaar gaf de helft van de bedrijven aan het POP in te zetten voor de meerderheid van het technisch personeel. Het bedrijfsopleidingsplan werd in 2014 juist door meer bedrijven ingezet dan in 2013.

\section{(C) Volgen van scholing}

Bij het faciliteren van de scholingsdeelname van het technisch personeel maken bedrijven veruit het meeste gebruik van scholings- en ontwikkelingsgesprekken. Ruim de helft van de metalektrobedrijven voerde deze gesprekken in 2014 met de meerderheid van hun technisch personeel. Dit aandeel is kleiner in vergelijking met 2013; toen dit nog 66\% bedroeg. Leren onder werktijd blijkt juist te zijn toegenomen. In 2014 werd leren onder werktijd door 44\% van de bedrijven genoemd, terwijl dit in 2013 30\% bedroeg. $36 \%$ van de metalektrobedrijven heeft een bedrijfsopleidingsbudget. In één op de vijf bedrijven zijn opleidingsdagen ingezet. ${ }^{9}$

\section{(D) Opdoen van de gewenste werkervaring}

De ontwikkeling van kennis en vaardigheden van het technisch personeel kan gefaciliteerd worden door hen nieuwe werkervaring op te laten doen (on-the-job-training). Evenals in 2013 werd in 2014 bij bijna 30\% van de bedrijven gebruik gemaakt van functieroulatie. Werknemers kunnen ook leren van uitwisseling met collega's van andere bedrijfsvestigingen. Dit blijkt echter nauwelijks te worden toegepast.

9 Voor wat betreft opleidingsdagen kan geen percentage voor 2013 worden gegeven, omdat dit HR-instrument pas in 2014 als antwoordcategorie aan de enquêtevraag is toegevoegd. 
Bij de hoefijzerfabriek van Werkman Horseshoes wordt steeds intensiever ingezet op scholing, zo stelt de directie. Voor alle activiteiten op dit gebied wordt samengewerkt met het kennis- en adviescentrum voor technisch vakmanschap Kenteq. Samen met Kenteq is onder andere een breed opleidingsprogramma samengesteld dat tot stand kwam door een aantal stappen te doorlopen. Allereerst zijn de competenties waarover het personeel beschikt vastgesteld door middel van EVC's, wat kan worden beschouwd als een nulmeting. Hiermee wordt duidelijk over welke kennis, competenties en talenten medewerkers zoal beschikken en wordt tevens een beeld verkregen van hun ambities. Na het opstellen van de EVC's zijn er voor de verschillende soorten functies binnen het bedrijf functiecompetentieprofielen samengesteld. Vervolgens zijn de competenties uit de EVC's en de functiecompetentieprofielen naast elkaar gelegd om te inventariseren welke opleidingsbehoeften er in brede zin zijn en welke mogelijkheden er zijn voor de verschillende werknemers. Per werknemer is vervolgens vastgesteld welke ontwikkeling en opleiding (persoonlijke opleidingsplannen) er nodig is. Daarnaast is er een bedrijfsopleidingsplan opgesteld. $0 \mathrm{~m}$ dit traject soepel te laten verlopen is een speciale projectgroep in het leven geroepen die bestaat uit één vertegenwoordiger per functiegroep. De intentie van deze projectgroep is onder meer om iedereen mee te krijgen in de doelstellingen op het gebied van scholing en ontwikkeling. De projectgroep dient werknemers te motiveren en enthousiasmeren en heeft hierdoor als het ware een 'masserende werking', aldus Christel Werkman, codirecteur van de hoefijzerfabriek.

Het gevolg van de samenwerking met Kenteq en het opstellen van de ontwikkelingsplannen is dat er nu gerichter wordt gewerkt aan de scholing en ontwikkeling van medewerkers van Werkman en dat het bedrijf nu op een structurele manier bezig is met de opleiding en ontwikkeling van zijn medewerkers. 


\section{5 \\ ORGANISATIE VAN HET WERK BINNEN DE METALEKTRO}

Evenals in voorgaande jaren concentreerden organisatorische veranderingen zich in 2014 niet zozeer op de manier waarop het bedrijf wordt geleid, maar vooral op de manier waarop het werk wordt georganiseerd. Voor de komende drie jaar worden de variabele inzet van het eigen technisch personeel en het projectmatig werken het meest genoemd als verwachte organisatorische veranderingen.

De mate waarin metalektrobedrijven behoefte hebben aan breed inzetbaar personeel is in 2014 licht gestegen. Ongeveer 70\% van de bedrijven had in 2014 in (zeer) sterke mate behoefte aan breed inzetbare uitvoerende technici. Deze behoefte blijkt het grootst onder grote bedrijven. Als belangrijkste reden voor de behoefte aan breed inzetbare technici wordt 'het opvangen van schommelingen in de bedrijfsdrukte' genoemd.

Aanvullende data laat zien dat er relatief veel arbeidsautonomie is in de Metalektro. In vergelijking tot andere Europese Metalektro sectoren, scoort de Nederlandse Metalektro vrij hoog op arbeidsautonomie. Een hoge mate van arbeidsautonomie is internationaal gezien belangrijk omdat de mate van autonomie van werknemers een bijdrage levert aan de concurrentiekracht. ${ }^{10}$ Er lijkt echter over het algemeen een dalende trend te zijn in de mate waarin werknemers zelf kunnen beslissen hoe hun dagelijks werk is georganiseerd. Dit geldt niet alleen voor de Metalektro, maar voor alle Nederlandse sectoren.

10 De Hoorn (2014) Sociale innovatie en de concurrentiekracht van sectoren, Economisch Statistische Berichten, jaargang 100 (4702), 42-45. 


\subsection{Vaakst genoemde organisatorische verandering is de variabele inzet van technisch personeel}

Dit hoofdstuk heeft betrekking op de manier waarop het werk binnen de Metalektro georganiseerd is en op de recente en toekomstige veranderingen op dit terrein. Allereerst bespreken we of zich organisatorische veranderingen hebben voor gedaan binnen de metalektrobedrijven. Vervolgens bespreken we twee belangrijke factoren die inzicht geven in de manier waarop het werk binnen de sector georganiseerd wordt; de vraag naar breed inzetbaar personeel en de mate van arbeidsautonomie. Voor de analyse van arbeidsautonomie wordt op basis van een externe dataset een vergelijking met andere Nederlandse sectoren en met de Metalektro in andere Europese landen gemaakt. Als laatste gaan we in dit hoofdstuk in op externe samenwerking als organisatorische verandering.

\section{Organisatorische veranderingen vooral gericht op de organisatie van het werk}

Figuur 5.1 toont in hoeverre bedrijven in 2014 een organisatorische verandering hebben ondergaan. lets minder dan de helft (45\%) van de bedrijven heeft geen organisatorische verandering doorgevoerd. Een krappe meerderheid heeft dus minimaal één verandering doorgevoerd. Ook in 2013 was dit het geval. Het is opvallend dat de meest doorgevoerde organisatorische veranderingen betrekking hebben op de manier waarop het werk wordt georganiseerd, en niet zozeer op de manier waarop het bedrijf wordt geleid. Evenals in de afgelopen jaren hebben decentralisatie en het verminderen van het aantal managementlagen nauwelijks plaatsgevonden. De variabele inzet van het eigen technisch personeel (20\%) en het projectmatig werken (16\%) zijn in 2014 het meest genoemd als veranderingen met betrekking tot de manier waarop het werk georganiseerd wordt. Ook voor de komende drie jaar worden deze organisatorische veranderingen het meest verwacht respectievelijk 38\% en $20 \%$. Metalektrobedrijven verwachten ook vaak organisatorische veranderingen met betrekking tot samenwerking. Hier gaan we in paragraaf 5.4 nog verder op in.

De vier organisatorische veranderingen die in 2014 het meest doorgevoerd zijn hebben zoals gezegd allemaal betrekking op de organisatie van het werk: werken in teams, taakintegratie over afdelingen, projectmatig werken en variabele inzet van het eigen technisch personeel. Uit eerdere metingen is gebleken dat bedrijven dit type organisatorische veranderingen met name doorvoeren omdat zij de productie willen flexibiliseren (Gerards et al, 2014). ${ }^{11}$ Om in deze behoefte te kunnen voldoen, is het aannemelijk dat deze organisatorische veranderingen vragen om breed inzetbaar personeel.

11 Gerards, de Grip, de Hoon, Künn-Nelen en van Thor (2014). Arbeidsmarktmonitor Metalektro 2013, ROA-R$2014 / 4$. 
FIGUUR 5.1 Gerealiseerde en verwachte organisatorische veranderingen (\% bedrijven), 2014

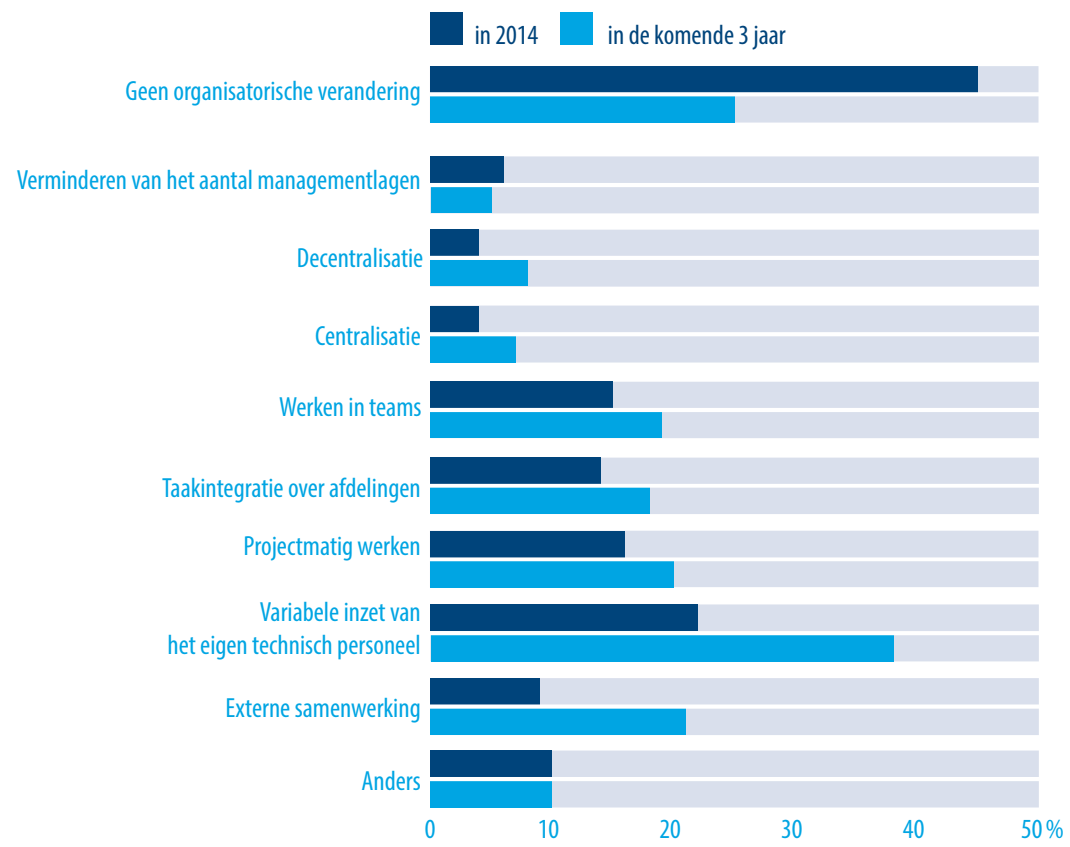

Bron: ROA, Arbeidsmarktmonitor Metalektro, 2014

\subsection{Behoefte van bedrijven aan breed inzetbaar personeel verschilt sterk per functiecategorie}

In Figuur 5.2 is de behoefte aan breed inzetbaar personeel voor 2014 weergegeven. Ten opzichte van 2012 en 2013 blijkt er in 2014 gemiddeld genomen sprake te zijn van een licht gedaalde, maar nog altijd grote behoefte aan breed inzetbaar personeel: $70 \%$ van de metalektrobedrijven had in 2014 in (zeer) sterke mate behoefte aan breed inzetbare uitvoerende technici. Daar bovenop had nog een kwart van de bedrijven in beperkte mate behoefte aan breed inzetbare uitvoerende technici. De behoefte aan breed inzetbaar personeel in de ondersteunende technische functies was in 2014 31\%. Bedrijven hebben maar relatief weinig behoefte aan brede inzetbaarheid van werknemers in engineering en R\&D functies en het laagst is de behoefte aan breed inzetbare technisch opgeleide verkopers. Maar liefst 35\% van de bedrijven geeft aan dat laatst genoemden niet breed inzetbaar hoeven te zijn. Dit geeft aan dat dit een zeer specialistische functie is. 
FIGUUR 5.2 Behoefte aan breed inzetbaar personeel naar functiecategorie (\% bedrijven), 2014

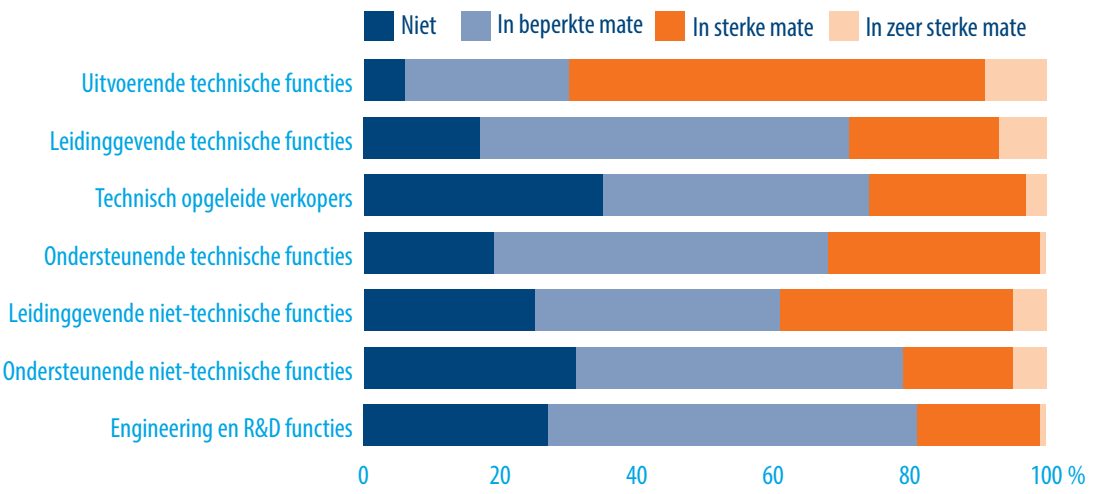

Bron: ROA, Arbeidsmarktmonitor Metalektro, 2014

In Figuur 5.3 gaan we nader in op de behoefte aan breed inzetbare uitvoerende technici en geven deze behoefte weer naar bedrijfsgrootte. Opvallend is dat alle bedrijven met meer dan 250 medewerkers aangeven behoefte te hebben (in beperkte, sterke of zeer sterke mate) aan breed inzetbare uitvoerende technici. Onder de bedrijven met minder dan 250 medewerkers geeft telkens een klein percentage aan geen behoefte te hebben aan breed inzetbaar technisch uitvoerend personeel. Dit suggereert dat er juist in deze kleine(re) bedrijven meer specialisatie is dan in grotere bedrijven. Vermoedelijk opereren deze bedrijven in een nichemarkt waardoor ze een hoge mate van specialisatie kennen en geen behoefte hebben aan breed inzetbare technici.

FIGUUR 5.3 Behoefte aan breed uitvoerend technisch personeel naar bedrijfsgrootte (\% bedrijven), 2014

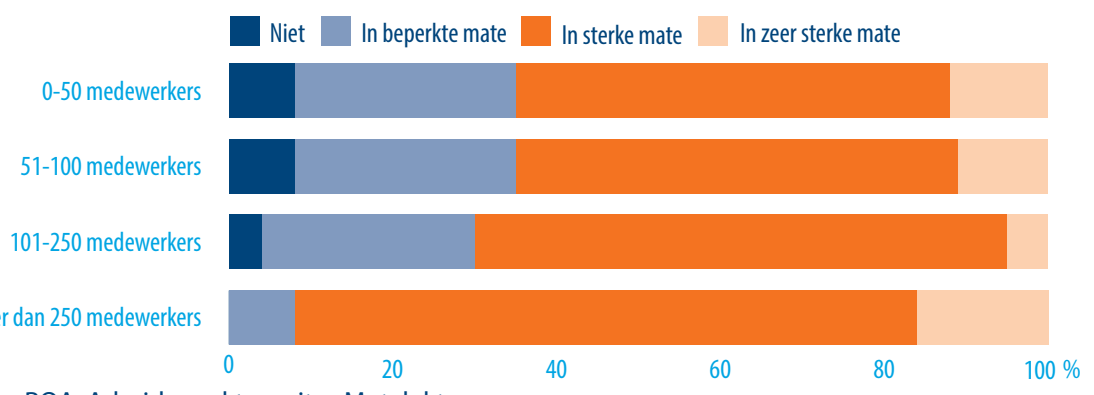

Bron: ROA, Arbeidsmarktmonitor Metalektro, 2014

Vooral ten aanzien van uitvoerende technici meer behoefte aan brede inzetbaarheid dan beschikbaar

In Figuur 5.4 wordt weergegeven in hoeverre daadwerkelijk aan de behoefte aan breed inzetbaar personeel wordt voldaan. Het is opvallend dat bij uitvoerende technici geldt dat maar liefst een op de drie werkgevers aangeeft dat de behoefte groter is dan de 
beschikbaarheid (zie Tekstbox 5.1 voor een praktijkvoorbeeld). Dit is problematisch gezien de grote omvang van de groep uitvoerende technici in de sector. Het is bovendien opvallend, omdat vorig jaar maar liefst $93 \%$ van de bedrijven aangaf dat hun uitvoerend technisch personeel (meer dan) voldoende breed inzetbaar was. Voor alle andere functiecategorieën geeft hooguit een vijfde van de bedrijven aan dat de behoefte groter is dan beschikbaar. Aan de behoefte aan breed inzetbaar engineering en R\&D personeel wordt het meest voldaan (in $85 \%$ van de bedrijven).

FIGUUR 5.4 Verhouding tussen behoefte en beschikbaarheid breed inzetbaar personeel (\% bedrijven), 2014

Behoefte kleiner dan beschikbaar Behoefte gelijk aan beschikbaar _ Behoefte groter dan beschikbaar

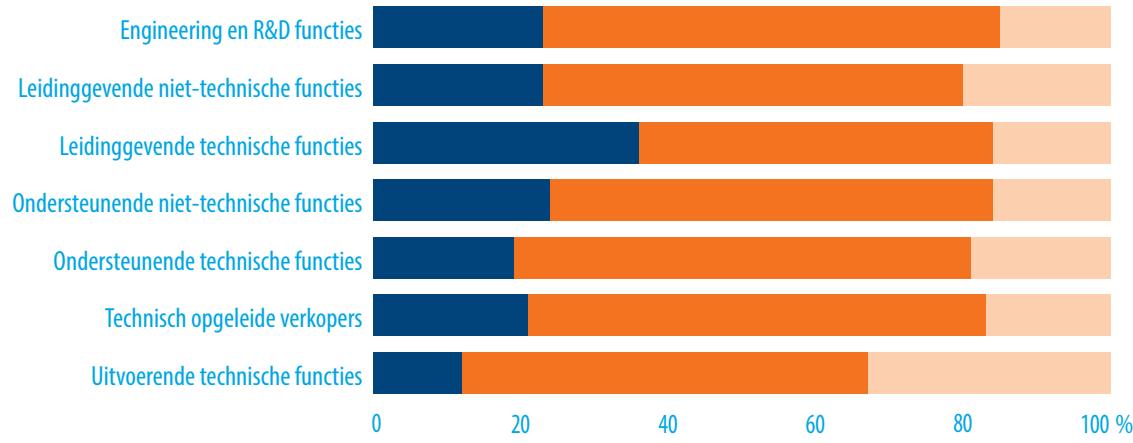

Bron: ROA, Arbeidsmarktmonitor Metalektro, 2014

TEKSTBOX 5.1 Personeel ziet belang van brede inzetbaarheid niet altijd in

Ook bij het familiebedrijf Werkman Horseshoes, waar sinds 1906 hoefijzers geproduceerd worden, is er behoefte aan breed inzetbaar personeel. Volgens directeur Hero Werkman is het echter moeilijk om mensen te vinden die op verschillende plekken binnen de organisatie aan het werk kunnen en die meewillen met vernieuwingen. Het besef dat bredere inzetbaarheid of een extra opleiding de employability ten goede komt is vaak onvoldoende aanwezig. Dit levert een spanningsveld op met de ambities die het bedrijf heeft op het gebied van brede inzetbaarheid en innovatie. Bij Werkman wordt daarom voortdurend geprobeerd om het personeel bewust te maken van het belang van een brede inzetbaarheid en extra opleiding/scholing voor zowel het bedrijf als de werknemers zelf (Zie ook Tekstbox 4.2). In samenwerking met het kennis- en adviescentrum voor technisch vakmanschap Kenteq zijn er bijvoorbeeld speciale coachsessies georganiseerd voor het personeel en heeft men geprobeerd door functieroulatie de inzetbaarheid van het personeelsbestand te verbreden.

Omdat de behoefte aan brede inzetbaarheid onder uitvoerende technici het grootst is, wordt in Figuur 5.5 ingegaan op de achterliggende redenen voor deze behoefte. Evenals in eerdere jaren, staat de mogelijkheid om schommelingen in de bedrijfsdrukte op te vangen bovenaan in de lijst. Maar liefst $75 \%$ van de bedrijven geeft aan dat dit een belangrijke reden is voor de behoefte aan breed inzetbare uitvoerende tech- 
nici. Vervanging tijdens afwezigheid staat op plaats twee, met $60 \%$ van de bedrijven. Product- en/of procesvernieuwingen worden door $47 \%$ van de bedrijven genoemd. Deze drie meest genoemde redenen om breed inzetbare technici te willen hebben allen betrekking op de bedrijfsvoering: de continuïteit van en vernieuwing in de productie. $39 \%$ van de bedrijven noemt echter ook een reden die mede vanuit de interesses van het personeel gemotiveerd lijkt: het aantrekkelijker maken van de functies. Hiermee bieden deze bedrijven hun personeel door hun brede inzetbaarheid leuke, aantrekkelijke banen. Bedrijven kunnen hiermee voorkomen dat medewerkers een andere werkgever zoeken, omdat ze hun functie op een gegeven moment te saai vinden worden. Zie Tekstbox 5.2 voor een praktijkvoorbeeld hiervan.

FIGUUR 5.5 Redenen voor de behoefte aan breed inzetbare uitvoerende technici (\% bedrijven), 2014

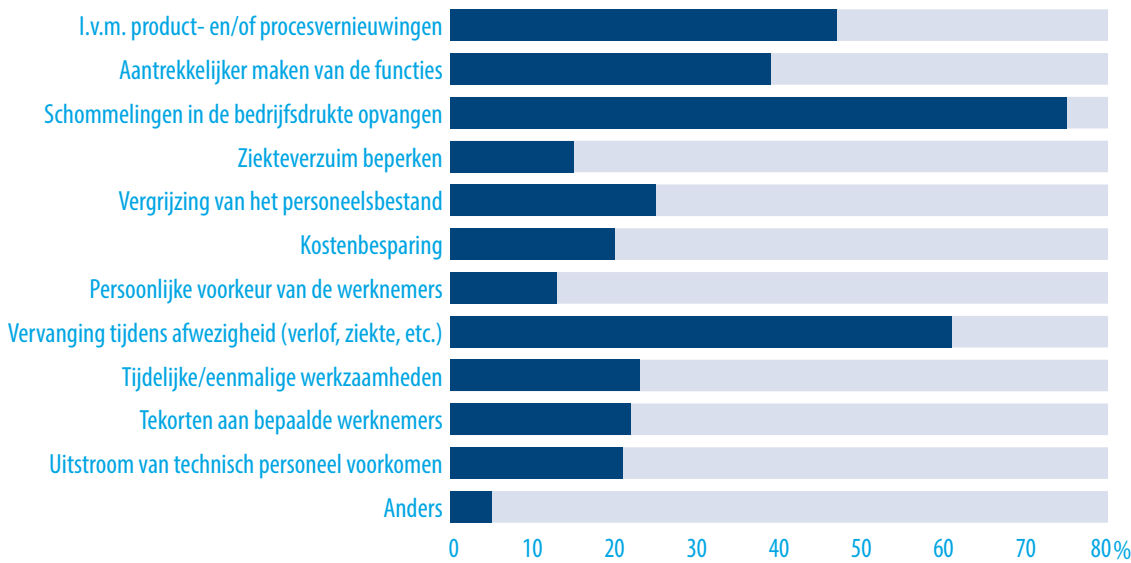

Bron: ROA, Arbeidsmarktmonitor Metalektro, 2014

Bij Ardagh in Deventer, producent van verpakkingen, blijven werknemers over het algemeen lang werkzaam bij het bedrijf. Volgens HR manager Herman van der Donk is dit het geval omdat een monteur bij Ardagh ook het leuke werk mag doen. Zo hebben monteurs veel autonomie, mogen ze vaak hun eigen kwaliteitscontroles uitvoeren en probeert Ardagh de functies zo breed en interessant mogelijk te houden. $0 \mathrm{~m}$ functies breed, veelzijdig en interessant te houden worden bijvoorbeeld verschillende projectgroepen opgezet. Zo kunnen medewerkers onder meer participeren in verschillende verbeterprojecten, waarbij zij gezamenlijk aan zowel horizontale als verticale verbeteringen in de organisatie kunnen werken. “De mensen die hier werken kunnen heel veel dingen zelf beïnvloeden. Daarnaast leidt het feit dat we het als bedrijf goed doen ertoe dat werknemers trots zijn op het bedrijf." 


\subsection{Arbeidsautonomie in de Nederlandse Metalektro: een vergelijking met andere landen en sectoren}

Door middel van de European Social Survey (ESS) is het mogelijk om inzicht te krijgen in de mate waarin binnen de Metalektro sprake is van arbeidsautonomie. ${ }^{22}$ Arbeidsautonomie wordt in de ESS gemeten door aan respondenten te vragen om aan te geven "in hoeverre de directie op uw werk u toestaat/toestond om te beslissen hoe uw dagelijks werk is/was georganiseerd". Zij konden antwoorden op een 10-punt schaal die loopt van" ik heb/had geen invloed" tot "ik bepaal(de) dat helemaal zelf". Tekstbox 5.2 geeft een illustratie van hoe arbeids-autonomie van waarde kan zijn voor zowel werknemers als werkgever. Aan de hand van tweecijferige zogeheten 'NACE-codes' wordt de sector waarin respondenten werkzaam zijn geregistreerd. Zo is het mogelijk om per sector een gemiddelde arbeidsautonomie te bepalen.

FIGUUR 5.6 Arbeidsautonomie in de Metalektro en Nederland als geheel tussen 2002 en 2012 (op de schaal van 1 tot 10 )
Metalektro
Nederland

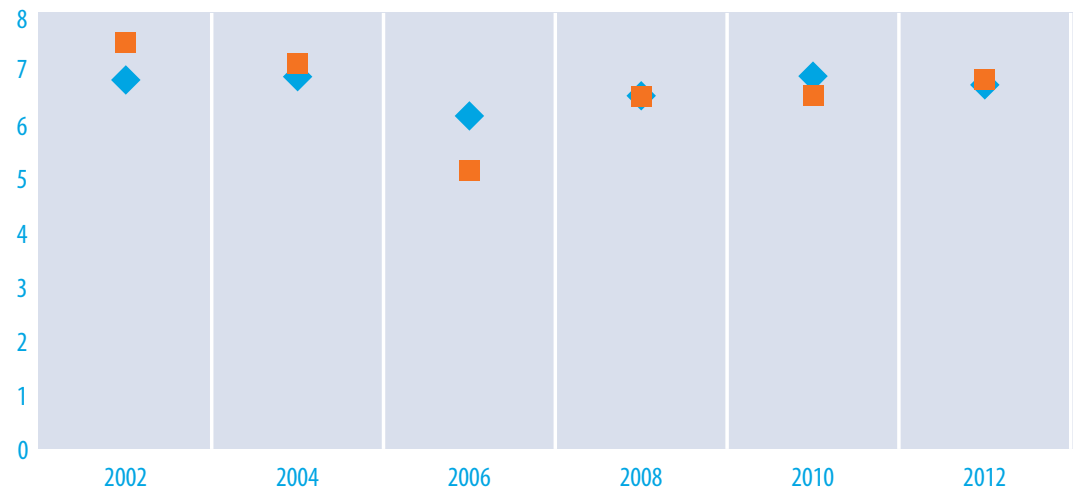

Bron: ESS 2002-2012

In Figuur 5.6 is te zien hoe de arbeidsautonomie zich binnen de Nederlandse Metalektro (NACE codes 24-30) en gemiddeld in alle Nederlandse sectoren heeft ontwikkeld tussen 2002 en 2012. In 2002 was de arbeidsautonomie binnen de Metalektro relatief hoog. Gemiddeld gaven de respondenten de arbeidsautonomie bijna een 7,5 op de schaal van 1 tot 10. Over het algemeen lijkt er echter wel een dalende trend te zijn in de mate waarin werknemers in de Metalektro zelf kunnen beslissen hoe hun dagelijks werk is georganiseerd. Volgens signalen uit de sector is het hier zoeken naar de balans. $\mathrm{Na}$ enkele jaren waarin medewerkers meer autonomie werd gegeven, vragen medewerkers nu soms zelf weer om meer sturing. Daarnaast veroorzaken processen zoals standaardisatie en het werken in teams voor veranderingen in autonomie, omdat medewerkers hun aanpak moeten afstemmen op die van hun collega's. Een uitschieter naar beneden vormt daarnaast het jaar 2006, toen de metalektrowerknemers hun arbeidsautonomie

12 Voor meer informatie over deze survey, zie http://www.europeansocialsurvey.org 
een 5 gaven. ${ }^{13}$ Hetzelfde patroon van een dalende trend en een (iets kleinere) uitschieter in 2006 is ook terug te vinden wanneer we naar alle Nederlandse sectoren samen kijken. In de meeste jaren lijkt de arbeidsautonomie binnen de Metalektro redelijk gelijk aan die van Nederland in het algemeen.

In Figuur 5.7 wordt de arbeidsautonomie in zowel de Metalektro als in andere Nederlandse sectoren weergegeven. Op die manier kan gekeken worden of de arbeidsautonomie van de Metalektro landelijk gezien relatief hoog of laag is. Er zijn een aantal sectoren waarbij meer arbeidsautonomie gemeten is dan binnen de Metalektro, zoals de landbouw, bosbouw en visserij en openbaar bestuur en overheidsdiensten. Daarentegen zijn er ook een aantal sectoren te noemen waarbij een lagere arbeidsautonomie geldt. Hiertoe behoren de sectoren vervoer en opslag en de industrie. De industrie is een interessante sector omdat de Metalektro hiertoe behoort. Binnen de overkoepelende sector industrie blijkt de arbeidsautonomie iets lager te liggen dan binnen de Metalektro, maar het verschil is klein. Het lijkt hiermee dat de Metalektro binnen de industrie iets voorop loopt qua arbeidsautonomie.

\section{FIGUUR 5.7 Arbeidsautonomie in verschillende Nederlandse sectoren, 2012}

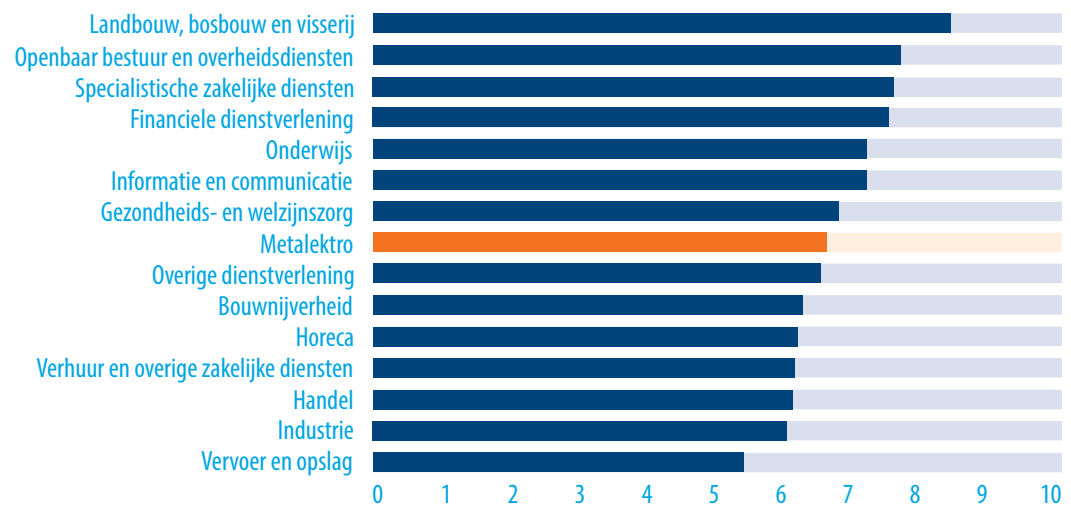

Bron: ESS 2012

Het is ook interessant om te kijken naar de arbeidsautonomie van de Nederlandse Metalektro in vergelijking met die in andere landen. Een reden hiervoor geeft De Hoorn (2014). Hij laat namelijk zien dat de mate van autonomie van werknemers een bijdrage levert aan de concurrentiekracht. ${ }^{14}$ Met name in landen waar het sociaal vertrouwen groot is, ondervinden sectoren met een hoge mate van arbeidsautonomie een concurrentievoordeel ten opzichte van dezelfde sectoren in landen waar minder sociaal vertrouwen of arbeidsautonomie is. In Figuur 5.8 is de gemiddelde arbeidsautonomie

13 Uit nadere analyses blijkt dat er geen samenhang is tussen de mate van arbeidsautonomie in de Metalektro en de brede inzetbaarheid of de omzet in de sector.

14 De Hoorn (2014), Sociale innovatie en de concurrentiekracht van sectoren, Economisch Statistische Berichten, jaargang 100 (4702), 42-45. 
van de Metalektro in verschillende Europese landen weergegeven. De Nederlandse Metalektro scoort internationaal gezien relatief hoog op de arbeidsautonomie. Alleen de Metalektro in Scandinavische landen en het Verenigd Koninkrijk scoren hoger. De Duitse Metalektro heeft een gemiddelde arbeidsautonomie die vergelijkbaar is met die in Nederland. Als we meerdere landen aan Figuur 5.7 zouden toevoegen, zouden deze bijna allemaal onder Nederland komen te staan. Met andere woorden, in de meeste Europese landen die niet in de figuur zijn opgenomen is de arbeidsautonomie binnen hun metalektro lager dan in de Nederlandse. Dit geldt bijvoorbeeld voor alle Midden- en Oost-Europese landen.

FIGUUR 5.8 Arbeidsautonomie in de Metalektro-sectoren in de EU-12, 2012

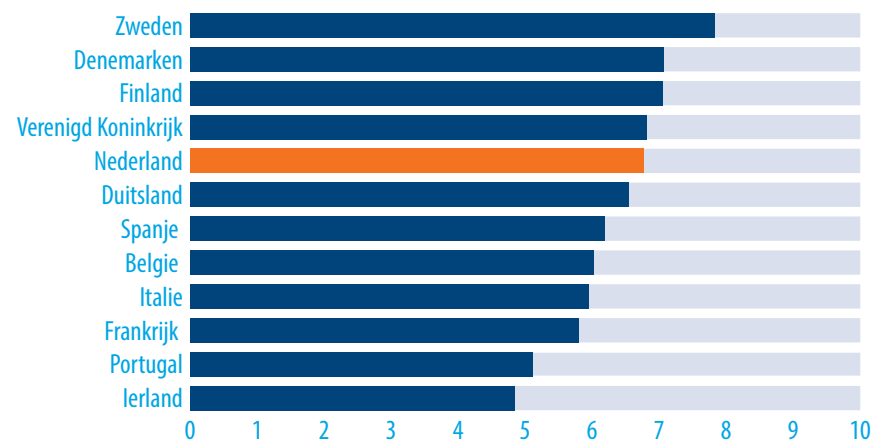

Bron: ESS 2012

\subsection{Externe samenwerking als organisatorische verandering}

Uit Figuur 5.1 is gebleken dat ruim 20\% van de metalektrobedrijven voor de komende drie jaar een organisatorische verandering verwacht in de vorm van een externe samenwerking. In Figuur 5.9 gaan we in op de mate waarin metalektrobedrijven in de nabije toekomst verwachten samen te werken met verschillende externe partijen. We onderscheiden samenwerking met andere bedrijven, maar ook met leveranciers, klanten en kennisorganisaties. Dit jaar is voor het eerst ook gevraagd naar samenwerking met gemeenten. De reden hiervoor is de invoering van de Participatiewet waardoor gemeenten verantwoordelijk worden om arbeidsgehandicapten te helpen zoeken naar een passende baan, bij voorkeur bij een 'gewone' werkgever. ${ }^{15}$ Als werkgevers er niet in slagen om de toegezegde banen te creëren dan worden, door middel van een quotum, bedrijven met meer dan 24 werknemers verplicht om arbeidsplaatsen voor arbeidsgehandicapten aan te bieden. Deze nieuwe wet zou dus, in theorie, tot veel nieuwe samenwerking tussen metalektrobedrijven en gemeenten kunnen leiden. Uit Figuur 5.9 blijkt echter dat gemeenten door metalektrobedrijven het minst genoemd worden als toekomstige samenwerkingspartij. Slechts $6 \%$ voorziet in de komende drie

15 http://www.rijksoverheid.nl/onderwerpen/participatiewet?utm_campaign=sea-t-subsidies-aparticipatiewet\&utm_term=participatiewet\&gclid=COXWm_Clw8QCFe7MtAodkmYAHw 
jaar een verandering in samenwerking met een gemeente. Wellicht is dit percentage zo laag omdat men al met gemeenten samenwerkt en dit continueert, terwijl de vraagstelling gericht was op samenwerking als toekomstige organisatorische verandering. De helft van de bedrijven verwacht een verandering op het gebied van externe samenwerking binnen de keten of met klanten. Ook het samenwerken binnen de sector wordt in bijna de helft van de bedrijven genoemd als het gaat om verwachte samenwerking in de komende drie jaar. Veranderingen met betrekking tot samenwerking met onderwijsinstellingen en kennisinstituten worden duidelijk minder verwacht.

\section{FIGUUR 5.9 Vormen van externe samenwerking in de komende 3 jaar (\% bedrijven)}

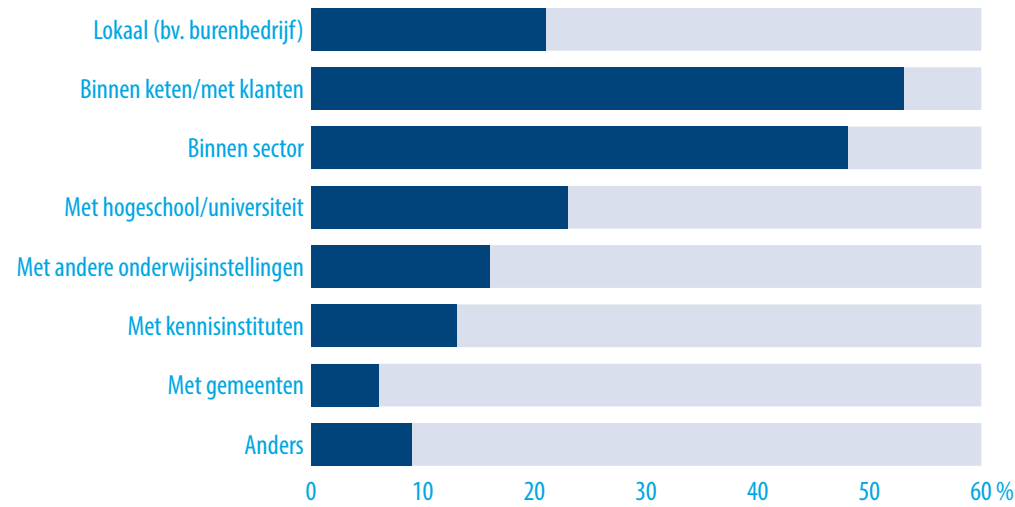

Bron: ROA, Arbeidsmarktmonitor Metalektro, 2014

TEKSTBOX 5.3 Actievere samenwerking met leveranciers

Bij Werkman Horseshoes is men sterk naar buiten gericht en ontplooit men veel samenwerkingen. Kennis delen en opnemen van anderen wordt steeds belangrijker in de organisatie, aldus directeur Hero Werkman. Dit uit zich onder andere in steeds meer verticale samenwerking met toeleveranciers en hoefsmeden. Vaste leveranciers hebben volgens Werkman veel kennis aan boord, komen daarnaast veel bij andere bedrijven over de vloer en kunnen Werkman dus van belangrijke tips voorzien. Procesinnovatie staat mede hierdoor continu op de agenda. Daarnaast heeft Werkman de Werkman Hoofcare Academy opgericht, waarin men samenwerkt met onder meer de universiteit van Leipzig om zoveel mogelijk kennis te ontwikkelen en te delen die voor hoefsmeden relevant is om hun vak uit te oefenen. 
Uit verschillende interviews is naar voren gekomen dat bedrijven behoefte hebben aan instroom van nieuwe jonge medewerkers met specifieke kennis en vaardigheden die nauw aansluiten bij wat in hun bedrijf nodig is en dat regionale samenwerking hierin een sleutelrol kan spelen.

Bij Royal Smit Transformers B.V., waar transformatoren geproduceerd worden, werd enkele jaren geleden hun toenmalige bedrijfsschool gesloten. Volgens senior personeelsfunctionaris Mèlanie Janssen-van Lendt werd echter al snel duidelijk dat de bedrijfsspecifieke kennis en vaardigheden die leerlingen van de bedrijfsschool ontwikkelden gemist werd binnen het bedrijf. Daarom is nadien in hechte samenwerking met Werk en Vakmanschap, een ROC en verschillende technische bedrijven uit de regio Nijmegen, een nieuwe BBL- opleiding mechatronica opgezet. In deze opleiding komen werktuigbouwkunde en elektronica samen, waardoor leerlingen van deze opleiding na het doorlopen van hun opleidingstraject over het algemeen breed inzetbaar zijn. Hiermee zijn de deelnemende bedrijven haast verzekerd van een kwalitatief goede aanwas van nieuwe jonge medewerkers die, door de BBL opzet, ook de cultuur van het bedrijf al hebben leren kennen. Nu deze opleiding er stevig staat, is in het samenwerkingsverband ook steeds meer aandacht komen te liggen op het enthousiasmeren en behouden van mensen voor technische beroepen. De bedrijven die deel uitmaken van het regionale samenwerkingsverband komen eens in de zes tot acht weken samen om onder meer de aanwezigheid van de deelnemende bedrijven op open dagen, beurzen, etc. te coördineren.

0ok bij Ardagh, waar glas- en metaalverpakkingen worden geproduceerd, leeft het besef dat het belangrijk is om jongeren te enthousiasmeren voor techniek en technische beroepen en dat samenwerking met het onderwijs en andere bedrijven in de regio hierin een belangrijke rol speelt. Herman van der Donk, HR-manager, wijst op het initiatief van de techniekcampus Deventer, een samenwerkingsverband in de stedendriehoek van Deventer, Apeldoorn en Zutphen. Deze campus moet hét opleidings- en innovatiecentrum voor techniek in de regio worden. Het betreft een samenwerkingsverband van bedrijven in 0.a. de bouw, Metalektro, metaal- en installatietechniek en het ROC. Volgens Van der Donk heeft dit initiatief geleid tot een toename van het aantal leerlingen dat kiest voor techniek en een toename van de kwaliteit van jonge technici in de regio.

Een specifieke vorm van samenwerking met andere bedrijven is het uitbesteden van eigen activiteiten aan een ander bedrijf. Uitbesteding kan zowel binnen als buiten Nederland plaatsvinden. Figuur 5.10 toont hoeveel procent van de bedrijven in 2014 verschillende activiteiten uitbesteed heeft. Omdat bedrijven een bepaalde activiteit (zoals productie) zowel binnen als buiten Nederland kunnen uitbesteden, tellen de percentages in de figuur niet op tot 100 . Uit de figuur maken we op dat productieactiviteiten het meest uitbesteed worden. $27 \%$ van de bedrijven besteedt een deel van de productie uit binnen Nederland, $13 \%$ van de bedrijven naar het buitenland. Administratieve activiteiten worden het minst vaak uitbesteed, in totaal slechts door $9 \%$ van de bedrijven. Als er al uitbesteding van administratieve activiteiten plaatsvindt, dan is dit vrijwel altijd binnen Nederland georganiseerd. Ook onderzoeksactiviteiten worden weinig uitbesteed. Het is overigens opvallend dat voor alle vormen van uitbe- 
steding geldt dat de percentages in 2014 beduidend lager zijn dan in 2013. Zo werd in 2013 nog door bijna 70\% van de bedrijven een deel van de productie uitbesteed. Meer dan $40 \%$ van de bedrijven besteedde in 2013 nog ondersteunende activiteiten uit. Deze ontwikkeling tussen 2013 en 2014 is extra opvallend omdat een overgroot deel van de bedrijven in 2013 aangaf dat zij geen wijzigingen in de omvang van hun uitbestedingen verwachten. Voor alle activiteiten gold dat minimaal drie kwart van de bedrijven van plan was de omvang van de uitbesteding binnen Nederland en buiten Nederland onveranderd te laten.

FIGUUR 5.10 Vormen van uitbesteding in 2014 (\% bedrijven)

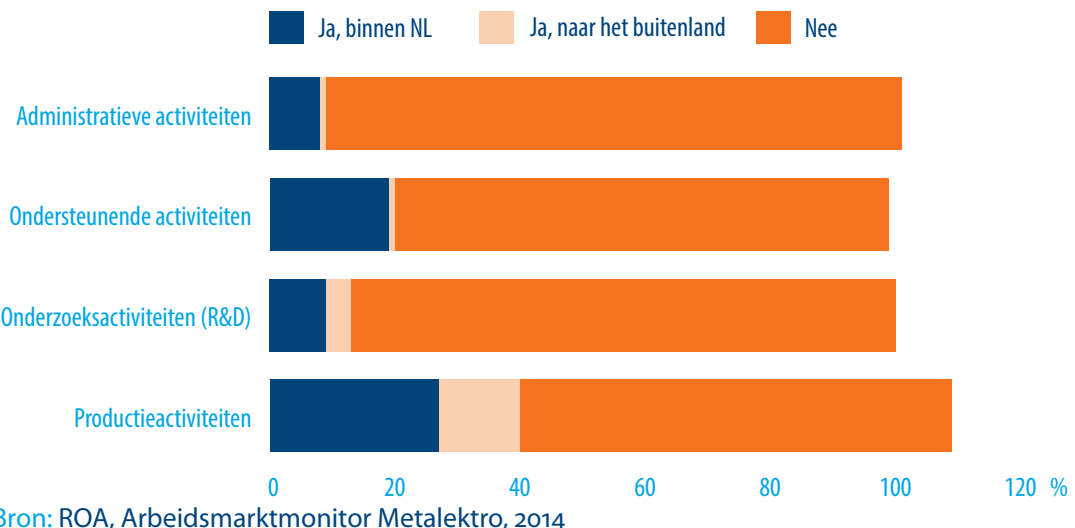

TEKSTBOX 5.5 Uitbesteding van productieactiviteiten

In verschillende interviews komt naar voren dat outsourcing plaatsvindt naar onder meer 0ost-Europese landen zoals Hongarije en Bulgarije, maar ook naar Italië. Bij Ardagh worden volgens HR-manager Herman van der Donk vooral de zeer arbeidsintensieve werkzaamheden uitbesteed.

Bij Miedema - producent van landbouwwerktuigen - betreft het volgens managing director René Boeijenga vooral technisch werk op een lager niveau dat uitbesteed wordt. Hij geeft aan dat het vaak lage arbeidsethos en het gebrek aan vakkennis bij lager opgeleide jonge werknemers in Nederland enkele van de belangrijkste redenen zijn om veel werk op laag niveau te automatiseren of te outsourcen naar het buitenland. Indien een grondige verbetering van het arbeidsethos van lager opgeleide jonge technici zou plaatsvinden in Nederland, zou dit het traject van outsourcing kunnen vertragen. Echter, het zal niet zo zijn dat de hele productie zal worden teruggehaald naar Nederland. 0ok staat voor Boeijenga vast dat nooit het hele productieproces naar Roemenië zal worden verplaatst, vanwege de Nederlandse handelsgeest en het hoge Nederlandse kennisniveau. 
In Figuur 5.11 wordt ingegaan op de verwachte verandering in de uitbesteding van activiteiten in het binnen- en buitenland. Uit de figuur blijkt dat bedrijven voor de komende drie jaar nauwelijks verandering verwachten in de omvang van hun uitbestedingen. Met uitzondering van uitbesteding van productieactiviteiten geldt dat meer dan $80 \%$ van de bedrijven verwacht dat de omvang van de uitbesteding niet verandert. De enige noemenswaardige verandering wordt dus verwacht bij uitbesteding van productieactiviteiten: $23 \%$ van de bedrijven verwacht een toename van uitbesteding hiervan binnen Nederland, terwijl 19\% van de bedrijven een toename van de uitbesteding hiervan naar het buitenland verwacht.

FIGUUR 5.11 Verwachte verandering in uitbesteding van activiteiten in de komende drie jaar (\% bedrijven)

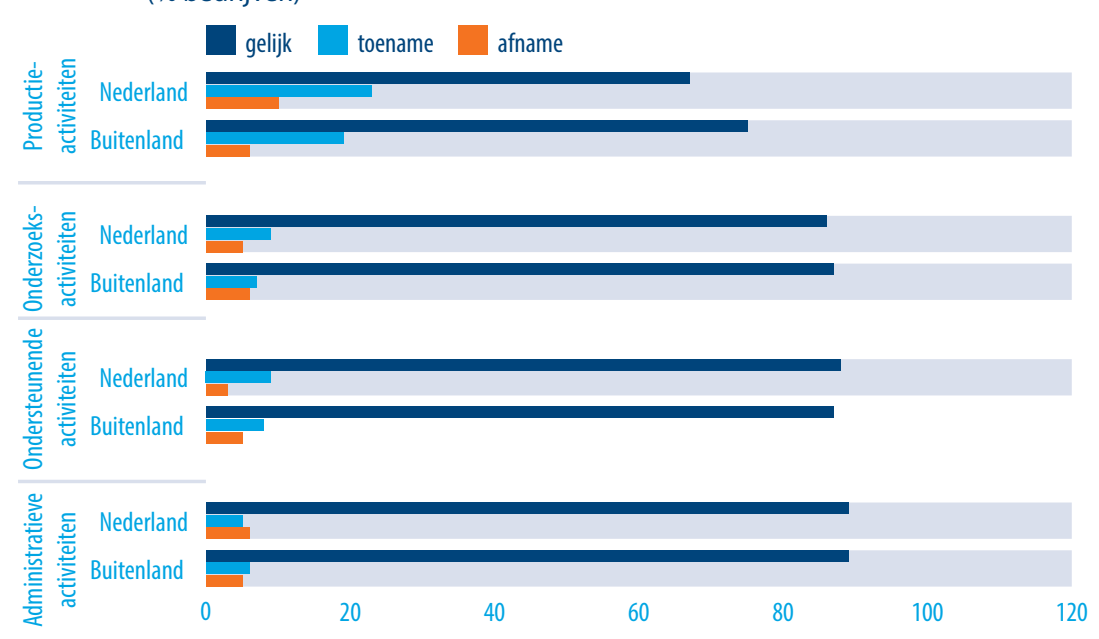

Bron: ROA, Arbeidsmarktmonitor Metalektro, 2014 



\section{6 \\ VERGRIJZING EN DUURZAME INZETBAARHEID}

Het personeel in de Metalektro ontgroent en vergrijst. Hoewel de gemiddelde leeftijd van de werkenden in de sector al sinds jaren onafgebroken toeneemt en in 2014 op 44,7 jaar lag, blijven de door de bedrijven voor de komende jaren verwachte vervangingsproblemen van personeel dat met pensioen gaat afnemen. Een mogelijke verklaring voor deze paradox ligt in de verplaatsing van werkzaamheden naar het buitenland of automatisering of robotisering van werkzaamheden (zie voorbeeld in Tekstbox 6.2). Daarnaast is het mogelijk dat pensioenuitstroom wordt gebruikt om een natuurlijk verlopende krimp vorm te geven, door niet al het uittredende personeel te vervangen. Bedrijven zijn nu echter ook beter ingesteld en voorbereid op de verwachte uitstroom van medewerkers die met pensioen gaan, zoals Figuur 6.6 verderop in dit hoofdstuk toont. De helft van de metalektrobedrijven nam één of meerdere maatregelen die specifiek gericht waren op het beperken van de verwachte vervangingsproblemen. Daarbij was het aannemen en zelf opleiden van nieuwe werknemers het meest populair. Daarnaast hebben steeds meer metalektrobedrijven aandacht voor de duurzame inzetbaarheid van hun personeel. Dit uit zich in een toenemend gebruik van active-aging instrumenten zoals het breder inzetbaar maken van medewerkers en aandacht voor hun (fysieke) belasting. 


\subsection{Leeftijdsopbouw Metalektro}

De vergrijzing van het werknemersbestand van de Metalektro is geen nieuwe ontwikkeling. De gemiddelde leeftijd van het personeel van metalektrobedrijven stijgt al jaren (tot 44,7 jaar in 2014) en zo ook het aandeel oudere werknemers (50-64 jaar). Dit verschijnsel doet zich niet enkel voor binnen de Metalektro. Over de gehele breedte van de arbeidsmarkt vergrijst de werkzame bevolking en neemt de netto-arbeidsparticipatie van 50 tot 65 -jarigen sterk toe $(C B S, 2013) .{ }^{16}$ Dit is niet vreemd, gezien de veroudering van de gehele bevolking en de flinke toename in participatie van ouderen als gevolg van verschillende beleidsmaatregelen genomen in de jaren 2006-2013. ${ }^{17}$ In deze periode is een opvallende ontwikkeling waar te nemen met betrekking tot het aandeel ouderen werkzaam in de Metalektro. Terwijl dit aandeel in de jaren tot 2011 telkens lager lag dan voor alle sectoren samen, nam het tussen 2010 en 2011 dermate toe - met ruim 2 procentpunt - dat sindsdien het aandeel ouderen binnen de Metalektro hoger ligt dan gemiddeld over alle sectoren (zie Figuur 6.1). Voorts steeg het percentage ouder personeel van metalektrobedrijven tussen 2011 en 2012 even hard als gemiddeld genomen over alle sectoren. Tussen 2012 en 2013 lopen de percentages weer verder uiteen; in dat jaar steeg het percentage 50-64 jarigen in de Metalektro harder dan gemiddeld genomen over alle sectoren.

FIGUUR 6.1 Percentage werkenden in de leeftijd 50-64 in de Metalektro en van alle sectoren in Nederland (2006-2013)

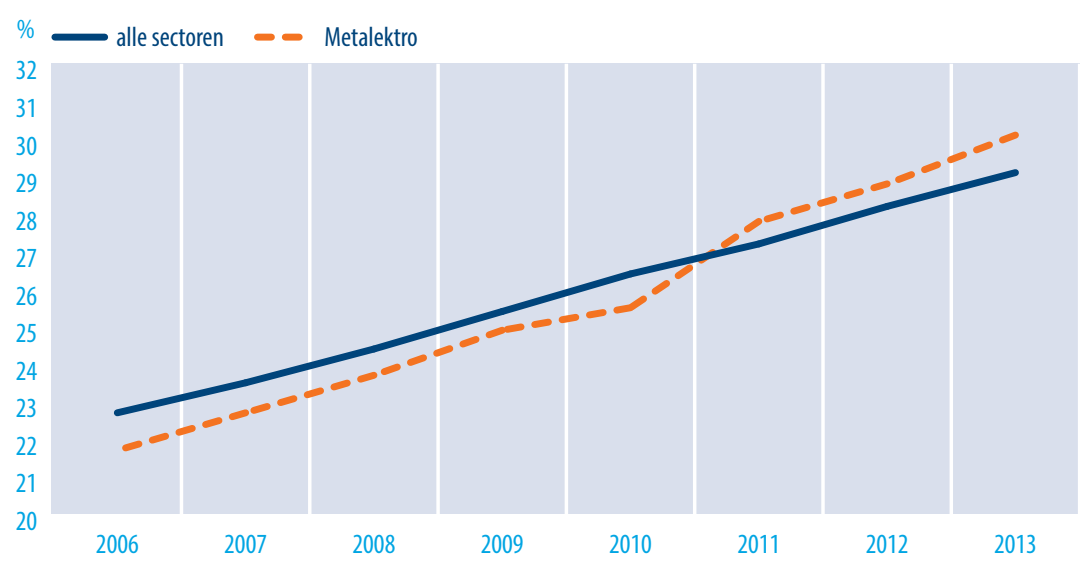

Bron: CBS, Enquête beroepsbevolking, 2006-2013

Figuur 6.1 laat zien dat de Metalektro in 2013 voor 30 procent uit oudere werknemers (leeftijd 50-64) bestond. Dit aandeel zal naar verwachting nog verder stijgen in de

16 CBS webmagazine, woensdag 10 april 2014. Auteurs: Koos Arts en Ferdy Otten.

17 Zoals de afschaffing van de fiscale bijdrage aan de VUT- en prepensioenregelingen, de verhoging van de fiscale arbeidskorting voor werkende ouderen in 2006 en de versnelde stijging van de AOW-en pensioengerechtigde leeftijd vanaf 2013. 
komende jaren. Recentere informatie over de leeftijdsopbouw van het personeelsbestand van de Metalektro is verkregen via het Pensioenfonds van de Metalektro (PME). Hoewel de EBB gegevens - welke zijn gebaseerd op een steekproef van de beroepsbevolking - heel bruikbaar zijn om een vergelijking te maken met andere sectoren, geven PME gegevens meer recente en gedetailleerde informatie over de leeftijdssamenstelling van werknemers in de Metalektro. Hiermee kan meer inzicht worden verkregen in de omvang van de groep die in de komende jaren naar verwachting uitstroomt naar pensionering.

In Figuur 6.2 is de leeftijdsverdeling van de Metalektro en van alle sectoren samen voor 2013 en 2014 in kaart gebracht. Door de verdelingen van deze twee jaren tegen elkaar af te zetten wordt duidelijk dat ook tussen 2013 en 2014 een veroudering heeft plaatsgevonden van werkenden in de Metalektro. De figuur toont voor de Metalektro namelijk een stijgend aandeel van werknemers in de leeftijden 55 tot 65 en 45 tot 55 . Daarentegen is het percentage medewerkers in de leeftijdscategorie 35-45 afgenomen. Voor de overige twee leeftijdscategorieën bleef het aandeel nagenoeg gelijk. Een vergelijking van de leeftijdsverdeling in de Metalektro met de leeftijdsverdeling over alle sectoren levert een interessant beeld op. Hoewel in beide gevallen de jongste leeftijdscategorie (15-25) de kleinste is van alle leeftijdscategorieën, is dit aandeel binnen de Metalektro drie keer kleiner dan voor alle sectoren samen (respectievelijk 3\% en 10\%). De groep 25-35-jarigen is eveneens relatief klein binnen Metalektrobedrijven (17\%) en aanzienlijk kleiner dan de groep oudere medewerkers (21\% in de leeftijden $55-65$ ). Voor alle sectoren samen is dit juist omgedraaid en vormt de groep 55-65-jarigen, na de leeftijdscategorie $15-25$, de kleinste groep werknemers. Hiermee is naast vergrijzing eveneens sprake van ontgroening in het werknemersbestand, en doen beide ontwikkelingen zich binnen de Metalektro in sterkere mate voor dan binnen de Nederlandse arbeidsmarkt als geheel.

FIGUUR 6.2 Leeftijdsopbouw in de Metalektro en alle sectoren 2013, 2014

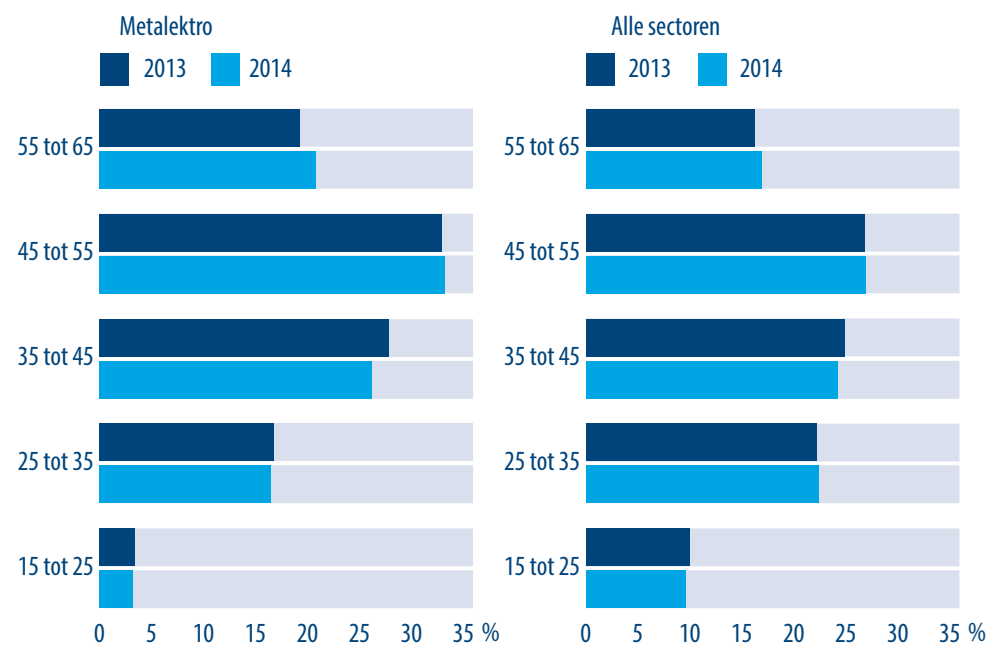

Bron: Metalektro: PME 2013-2014; Alle sectoren: CBS Enquête Beroepsbevolking 2013-2014 
De PME-gegevens over de leeftijdsopbouw van medewerkers in de Metalektro bieden de mogelijkheid om de pensioneringsuitstroom van de komende jaren te voorspellen. Als we uitgaan van het personeelsbestand van eind 2014 en een uittredeleeftijd van 65, levert dat in de komende vijf jaar (2015-2019) een pensioenuitstroom op van $8 \%$ van het totaal aantal werkenden. Dit betreft een gemiddelde prognose voor alle functiecategorieën binnen de Metalektro. Door de verhoging van de AOW-leeftijd zal dit percentage in werkelijkheid zeer waarschijnlijk lager liggen. De werknemers die eind 2014 de leeftijd van 64 hadden (geboortejaar 1950) zullen als gevolg van de gestegen AOW-leeftijd vaak met pensioen willen gaan wanneer zij 65,5 jaar oud zijn. 60-jarige werknemers (geboortejaar 1954) zullen als gevolg hiervan moeten doorwerken tot hun 67ste. Wanneer we een doorberekening maken op basis van de verhoogde AOW-leeftijd, zal in de komende vijf jaren (2015-2019) niet 8\% maar 4\% van de werknemers in de Metalektro met pensioen gaan. Hoewel de verhoging van de pensioensleeftijd ervoor zal zorgen dat mensen pas op latere leeftijd uit het arbeidsproces treden, moet er echter altijd rekeningen worden gehouden met vroegtijdige uittreding. Immers, de gemiddelde pensioenleeftijd in de praktijk lag in 2014 niet op 65, maar op 64, 1 jaar (CBS Statline). Hiermee rekening houdend zou het geprognosticeerde uitstroompercentage van $4 \%$ als absolute ondergrens kunnen worden beschouwd. Deze geldt voor het scenario waarin alle medewerkers tot hun verhoogde AOW-leeftijd blijven doorwerken.

Uit de theoretische exercitie in Tekstbox 6.1 blijkt dat het lastig is om de pensioneringsuitstroom voor de Metalektro als geheel te voorspellen, door de verschillende (onvoorspelbare) factoren die hierop van invloed zijn. In de arbeidsmarktmonitor Metalektro wordt ook ieder jaar aan de bedrijven zelf gevraagd hoeveel procent van hun medewerkers, per functiecategorie, zij verwachten dat met pensioen zal gaan in de komende jaren.

FIGUUR 6.3 Verwacht percentage medewerkers dat de komende vijf jaar met pensioen gaat (gemiddeld \% per technische functiecategorie), 2007-2014

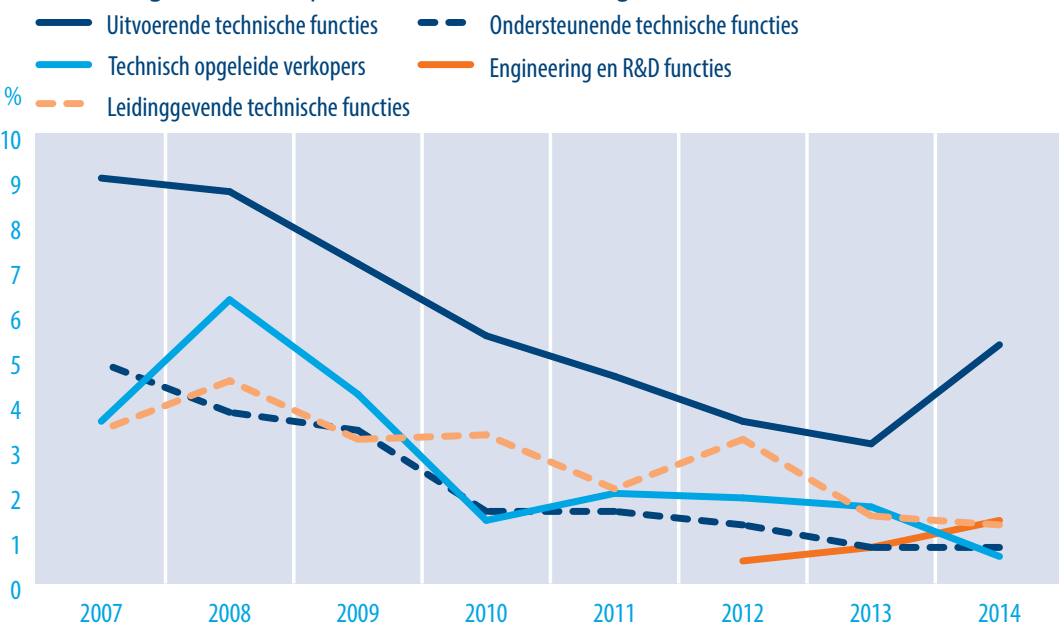

Bron: ROA, Arbeidsmarktmonitor Metalektro, 2007-2014 
Figuur 6.3 toont voor alle functiecategorieën een duidelijke afname in de verwachte pensioenuitstroom vanaf het begin van de economische crisis in 2008. Het verwachte aandeel werknemers dat in de nabije toekomst met pensioen gaat is - een enkele uitzondering daargelaten - gedaald tot in het jaar 2013. Voor wat betreft uitvoerende technici, lijkt in 2014 een breuk te zijn ontstaan in deze trend. Het voor de toekomst verwachte pensioneringspercentage werd in 2014 op $5 \%$ geschat, fors hoger dan in het voorgaande jaar 2013 (3\%).

\subsection{Vervangingsproblemen}

Uit de vorige paragraaf weten we dat het aantal oudere werknemers in de Metalektro relatief hoogt ligt, maar dat de verwachtingen van de bedrijven over de uitstroom naar pensioen relatief laag liggen. Het ligt voor de hand dat metalektrobedrijven dan ook weinig problemen verwachten om de werknemers die met pensioen gaan te vervangen. Om hier een indicatie van te krijgen is aan bedrijven gevraagd in hoeverre zij problemen tegemoet zien bij de vervanging van werknemers die in de komende vijf jaar met pensioen gaan. De resultaten hiervan zijn gegeven in Figuur 6.4. De lijnen in Figuur 6.4 geven aan hoe groot het aandeel bedrijven is dat voor de betreffende functiecategorie veel vervangingsproblemen verwacht in de komende vijf jaar. Over de gehele periode (2007-2014) is in grote lijnen een dalende trend waar te nemen; een steeds kleiner deel van de bedrijven verwacht veel vervangingsproblemen. Dit geldt voor alle functiecategorieën. Het begin van de economische crisis (2008) vormt een duidelijk omslagpunt. In dat jaar vond een forse daling plaats in het aandeel bedrijven dat veel vervangingsproblemen voorzag. In de twee jaren erna (2009 en 2010) sloeg de tendens voorzichtig om en voorzagen iets meer bedrijven grote problemen bij de vervanging van personeel dat met pensioen gaat. Vanaf 2011 daalt dit aandeel bedrijven dat veel vervangingsproblemen verwacht echter weer, ondanks de stijgende gemiddelde leeftijd en ondanks dat voor sommige functiecategorieën, zoals de uitvoerende technici, een stijgend percentage uittreders verwacht wordt (Figuur 6.3). Een mogelijke verklaring voor deze paradox ligt in de verplaatsing van werkzaamheden naar het buitenland of automatisering of robotisering van werkzaamheden (zie voorbeeld in Tekstbox 6.2). Daarnaast is het mogelijk dat pensioenuitstroom wordt gebruikt om een natuurlijk verlopende krimp vorm te geven, door niet al het uittredende personeel te vervangen. Tot slot zijn bedrijven nu beter ingesteld en voorbereid op de verwachte uitstroom van medewerkers die met pensioen gaan, zoals Figuur 6.6 verderop in dit hoofdstuk toont. 
FIGUUR 6.4 Vervangingsproblemen verwacht door pensionering in de komende vijf jaar (\% bedrijven met veel vervangingsproblemen, opgesplitst naar technische functiecategorie), 2007-2014

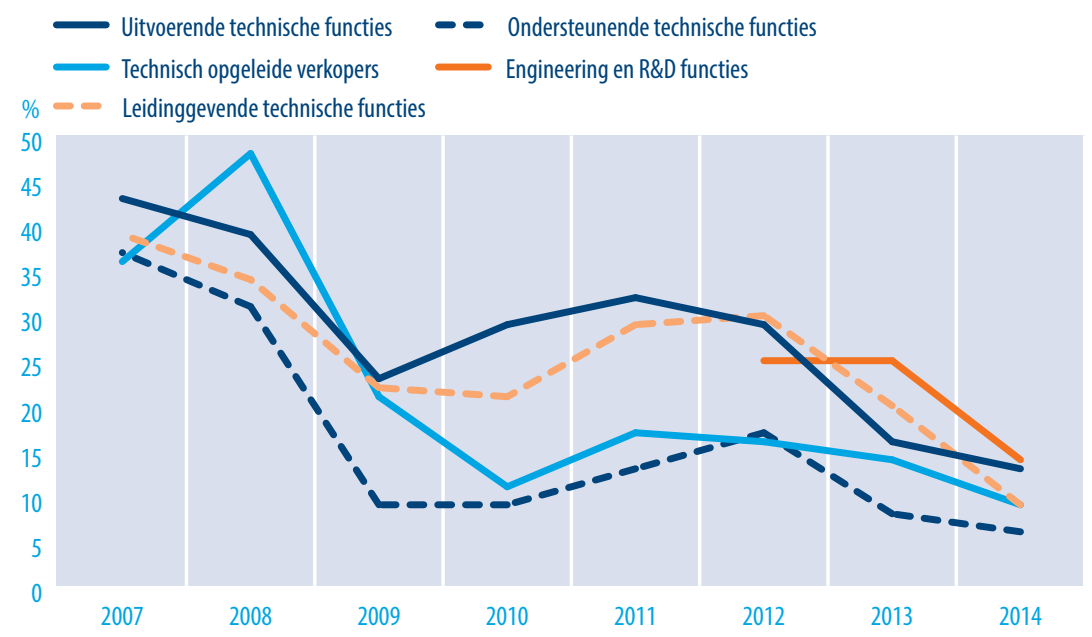

Bron: ROA, Arbeidsmarktmonitor Metalektro, 2007-2014

TEKSTBOX 6.2 Waarom vergrijzing in de praktijk soms voor maar weinig (vervangings)problemen zorgt

René Boeijenga - managing director bij Miedema, producent van landbouwwerktuigen - geeft aan dat ook zijn bedrijf te maken heeft met een vergrijzend personeelsbestand. De gemiddelde leeftijd van productiemedewerkers ligt rond de $\mathbf{5 0}$ jaar. Deze hoge gemiddelde leeftijd is echter geen groot probleem voor Miedema. Oudere werknemers met een fysiek zware baan kunnen bijvoorbeeld een mentorrol krijgen en op deze manier belangrijke kennis overdragen aan jongere medewerkers. Enkele jaren geleden was er bijvoorbeeld een industrieel spuiter die zich steeds meer ging bezig houden met het opleiden en mentoren van jonge, nieuwe spuiters. De betreffende medewerker kon door deze nieuwe rol deels ontlast worden in zijn fysiek zware beroep en ondertussen zijn kennis overdragen op een nieuwe generatie werknemers. De werknemer heeft inmiddels veel jonge spuiters opgeleid. Werknemers kunnen dus ook op hogere leeftijd nog steeds waarde toevoegen aan het bedrijf. De heer Boeijenga zegt hierover: 'de tijd dat we mensen afschrijven zodra ze 50 worden is echt voorbij'. 0ok wijst hij erop dat er nog steeds in scholing en opleiding van oudere werknemers geïnvesteerd wordt. Een tweede reden waarom vergrijzing niet echt een probleem is voor Miedema is dat een groot deel van de werkzaamheden die momenteel worden uitgevoerd door oudere werknemers, na pensionering van deze werknemers kunnen worden geautomatiseerd of verplaatst naar het buitenland. Voor maar ongeveer de helft van het aantal banen dat verdwijnt door pensionering is het volgens Boeijenga nodig om nieuwe mensen te werven. Echte vervangingsproblemen worden om die reden dan ook niet verwacht. 
Ook bij Werkman Horseshoes speelt het automatiseringsproces een belangrijke rol binnen de veroudering van het personeelsbestand en het opvangen van natuurlijk verloop: Door geleidelijke automatisering kunnen arbeidsplaatsen die vrijkomen door pensionering veelal opgevangen worden en is het werven van nieuwe medewerkers niet altijd nodig. Natuurlijk kunnen en zullen niet alle arbeidsplaatsen die vrijkomen na pensionering geautomatiseerd worden. Een groot deel van de werknemers die vertrekken zullen vervangen moeten worden door nieuwe mensen. Vervangingsproblemen doen zich hierbij echter nauwelijks voor. Doordat goed bijgehouden wordt over welke specifieke kennis en vaardigheden werknemers beschikken is bij uitstroom van personeelsleden door bijvoorbeeld pensionering volgens Hero Werkman meteen duidelijk naar wat voor soort mensen ze op zoek moeten gaan in termen van vereiste kennis en vaardigheden.

Ook Herman van der Donk van Ardagh in Deventer ziet de vergrijzing niet echt als een probleem: "we leven langer en blijven ook langer gezond, waardoor we in principe langer in staat zijn te blijven werken". Voor een groot deel is vergrijzing volgens Van der Donk slechts perceptie. "Tien jaar terug gingen veel mensen nog voor hun zestigste met pensioen en was de perceptie dat men dan al versleten was. Dat is nu alweer anders. We moeten er echter wel voor waken dat een stijgende gemiddelde leeftijd en het oprekken van de pensioenleeftijd er niet toe leidt dat we als bedrijf in slaapstand raken en er straks te weinig jongeren in de organisatie zitten". De toenemende gemiddelde leeftijd binnen Ardagh wordt volgens Van der Donk vooral gemerkt in de ploegen- en nachtdiensten. Naarmate werknemers ouder worden, levert het werk in ploeg- of nachtdienst soms problemen op. $0 \mathrm{~m}$ oudere werknemers die moeite hebben met het draaien van nacht- en/of ploegendiensten zoveel mogelijk te ontzien probeert Ardagh deze mensen, voor zover mogelijk, over te plaatsen naar een functie in dagdienst.

\subsection{Duurzame inzetbaarheid}

Bedrijven zullen ernaar streven de oudere werknemers die nog niet met pensioen gaan blijvend inzetbaar te houden. Hiertoe kan een breed scala aan HRM-instrumenten worden ingezet. Figuur 6.5 toont het gebruik van een aantal active-aging instrumenten - acties die bedrijven inzetten op het gebied van duurzame inzetbaarheid van het personeel. In zowel 2014 als 2013 zijn de meest gebruikte instrumenten het breder inzetbaar maken van medewerkers en aandacht voor (fysieke) belasting van medewerkers. Meer dan zeven op de tien bedrijven in 2014 gebruikten deze instrumenten in het kader van duurzame inzetbaarheid van de medewerkers. Voorts hield meer dan de helft (in 2014 zelfs $65 \%$ ) van de bedrijven rekening met de leeftijdsopbouw binnen het bedrijf bij het werven van nieuw personeel. Een kwart tot een derde van de bedrijven deed aan bevordering van een gezonde leefstijl, het bewaken van de balans tussen werk en privé en het bieden van de mogelijkheid om met deeltijdpensioen te gaan. Voorlichting over gezonde leefstijl en het regelmatig toetsen van werkdruk zijn instrumenten die door minder dan een kwart van de bedrijven werden ingezet met het oog op duurzame inzetbaarheid van het personeel. Voor de vijf meest populaire active-aging instrumenten geldt dat deze in 2014 door meer bedrijven werden ingezet dan in het jaar ervoor. De grootste toename is waar te nemen in het rekening houden met de leeftijdsopbouw binnen het bedrijf bij de werving van nieuw personeel; een toename in percentage 
bedrijven van 13\%-punt. Ook het bevorderen van een gezonde leefstijl en de aandacht voor fysieke belasting werden in 2014 door een significant groter percentage bedrijven ingezet dan in 2013.

FIGUUR 6.5 Gebruik van active-aging instrumenten ${ }^{18}$ (\% bedrijven), 2013 - 2014

$$
2013 \quad 2014
$$

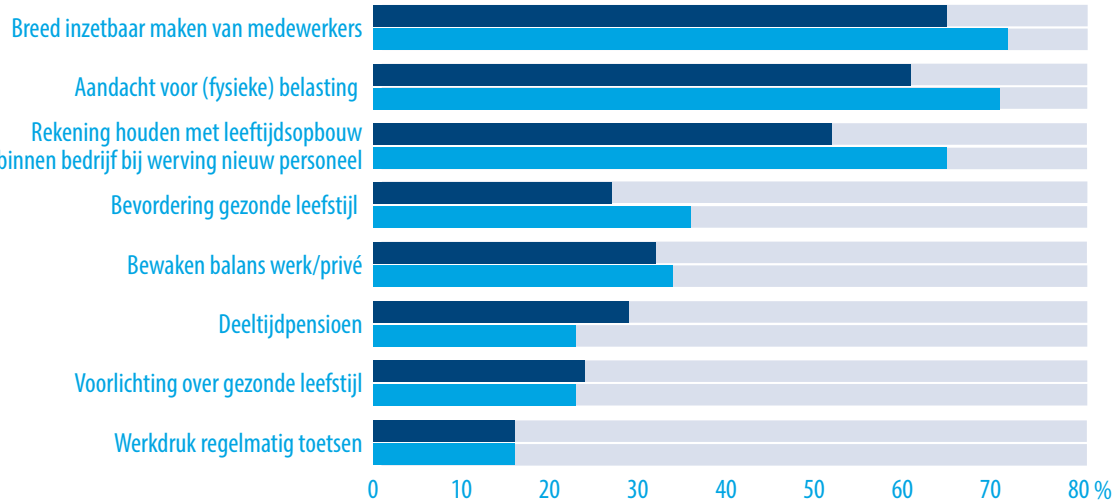

Bron: ROA, Arbeidsmarktmonitor Metalektro, 2013 - 2014

Om na te gaan in hoeverre metalektrobedrijven bij de inzet van HR instrumenten rekening houden met de leeftijd van hun medewerkers, is gevraagd om voor verschillende HR-maatregelen aan te geven of deze al dan niet worden aangeboden binnen het bedrijf en of deze vaker of minder vaak worden aangeboden aan personeel dat ouder is dan 45 jaar. Tabel 6.1 geeft hiervan de resultaten. Opleidingsmogelijkheden worden in alle metalektrobedrijven geboden. Daarnaast zijn loopbaangesprekken en het opstellen van een persoonlijk ontwikkelingsplan (POP) nog altijd veel gebruikt. Bijna driekwart van de bedrijven biedt mogelijkheden voor taakroulatie en het (gedeeltelijk) verrichten van ander werk.

Voor alle in 2014 ingezette HR-instrumenten geldt dat deze bij de meeste bedrijven even vaak aan alle werknemers, ongeacht leeftijd, werden aangeboden. Met andere woorden: in de meerderheid van de metalektrobedrijven is een groot deel van het HR-aanbod leeftijdsonafhankelijk. Slechts enkele HR-instrumenten werden door een klein deel van de metalektrobedrijven relatief vaak aan een specifieke leeftijdsgroep aangeboden. Het (gedeeltelijk) verrichten van ander werk, het verrichten van werkzaamheden waarbij de overdracht van kennis centraal staat en het verminderen van het aantal werkuren, worden door twee van de tien bedrijven vaker aangeboden voor werknemers in de leeftijd 45+. Dit duidt erop dat binnen deze bedrijven de (fysieke) belastbaarheid van oudere medewerkers mogelijk concreet wordt verlaagd. Een klein deel van de bedrijven biedt instrumenten zoals opleidingsmogelijkheden, loopbaangesprekken en het hanteren

18 Bedrijven konden hier meerdere instrumenten aanvinken. 
van een persoonlijk ontwikkelingsplan (POP) vaker aan, aan jongere dan aan oudere medewerkers.

TABEL 6.1 Aanbod van HR-instrumenten in 2014, algemeen en voor 45+/45- werknemers (\% bedrijven), 2014

\begin{tabular}{|c|c|c|c|}
\hline Ontwikkelinstrumenten en aanpassingen van het werk & $\begin{array}{l}\text { \% bedrijven } \\
\text { dat instrument } \\
\text { aanbiedt }\end{array}$ & $\begin{array}{l}\% \text { bedrijven dat } \\
\text { instrument relatief } \\
\text { vaker aan } 45+ \\
\text { aanbiedt }\end{array}$ & $\begin{array}{l}\% \text { bedrijven dat } \\
\text { instrument relatief } \\
\text { vaker aan } 45- \\
\text { aanbiedt }\end{array}$ \\
\hline Opleidingsmogelijkheden & 100 & 0 & 14 \\
\hline Loopbaangesprekken & 84 & 3 & 10 \\
\hline Persoonlijk Ontwikkelingsplan (POP) & 83 & 0 & 10 \\
\hline Taakroulatie & 74 & 4 & 5 \\
\hline (Gedeeltelijk) ander werk & 71 & 20 & 0 \\
\hline Opleidingsdagen & 70 & 0 & 2 \\
\hline $\begin{array}{l}\text { Werkzaamheden verrichten waarbij de overdracht van kennis } \\
\text { centraal staat }\end{array}$ & 60 & 20 & 2 \\
\hline Aantal werkuren verminderen & 58 & 20 & 0 \\
\hline Werken op andere tijden & 53 & 5 & 1 \\
\hline EVC & 38 & 3 & 3 \\
\hline Andere werkpatronen & 27 & 2 & 0 \\
\hline Persoonlijke inzetbaarheidsscan & 24 & 1 & 2 \\
\hline Loopbaancheck & 20 & 0 & 1 \\
\hline Ploegendienst anders organiseren & 17 & 3 & 0 \\
\hline
\end{tabular}

Bron: ROA, Arbeidsmarktmonitor Metalektro, 2014

\subsection{Voorkomen en beperken van vervangingsproblemen}

In paragraaf 6.2 was te zien dat metalektrobedrijven momenteel weinig vervangingsproblemen naar aanleiding van pensioneringen verwachten. Een aanzienlijk deel van de bedrijven (51\%) heeft dan ook in 2014 maatregelen genomen om deze mogelijke problemen bij voorbaat al in te perken. Figuur 6.6 toont de in 2014 genomen maatregelen en de maatregelen die door de meeste bedrijven worden genomen in de komende jaren. $29 \%$ van de bedrijven heeft nieuwe werknemers aangenomen die ze vervolgens zelf opleiden. In 2014 was dit de vaakst genomen maatregel in het kader van vervangingsproblematiek. Het breder inzetbaar maken van medewerkers werd in 2014 door ruim een kwart van de bedrijven benoemd als specifieke maatregel om vervangingsproblemen te beperken. Uit Figuur 6.6 blijkt vervolgens dat een relatief groot aandeel van de bedrijven (25\%) gebruik maakt van taakroulatie om deze bredere inzetbaarheid te bewerkstelligen. Taakroulatie kan worden beschouwd als een manier om te investeren in de ontwikkeling van nieuwe kennis en vaardigheden. Dit maakt dat 
medewerkers een ruimer pakket aan taken kunnen beoefenen, en variabeler kunnen worden ingezet wanneer zij bepaalde taken (zoals fysiek sterk belastende taken) niet meer kunnen uitvoeren (zie Tekstbox 6.3). Een even groot deel van de metalektrobedrijven neemt nieuwe, goede opgeleide werknemers aan om vervangingsproblemen te lijf te gaan. De overige maatregelen zijn door minder dan $20 \%$ van de bedrijven genomen. Voor bijna alle maatregelen geldt dat het aandeel bedrijven dat voornemens is de diverse HR-maatregelen te nemen - om vervangingsproblemen te beperken - in de komende jaren aanzienlijk groter is dan het aandeel bedrijven dat de betreffende maatregelen al heeft toegepast in 2014. We kunnen hieruit concluderen dat metalektrobedrijven hun inspanningen om vervangingsproblemen te beperken in de nabije toekomst sterk denken op te schroeven. Het is mogelijk dat deze toekomstige maatregelen mede verklaren waarom slechts weinig bedrijven veel vervangingsproblemen verwachten (Figuur 6.4).

FIGUUR 6.6 HR-maatregelen om problemen met de vervanging van gepensioneerde technici te beperken (\% bedrijven), 2014

2014 komende 5 jaar (2015-2019)

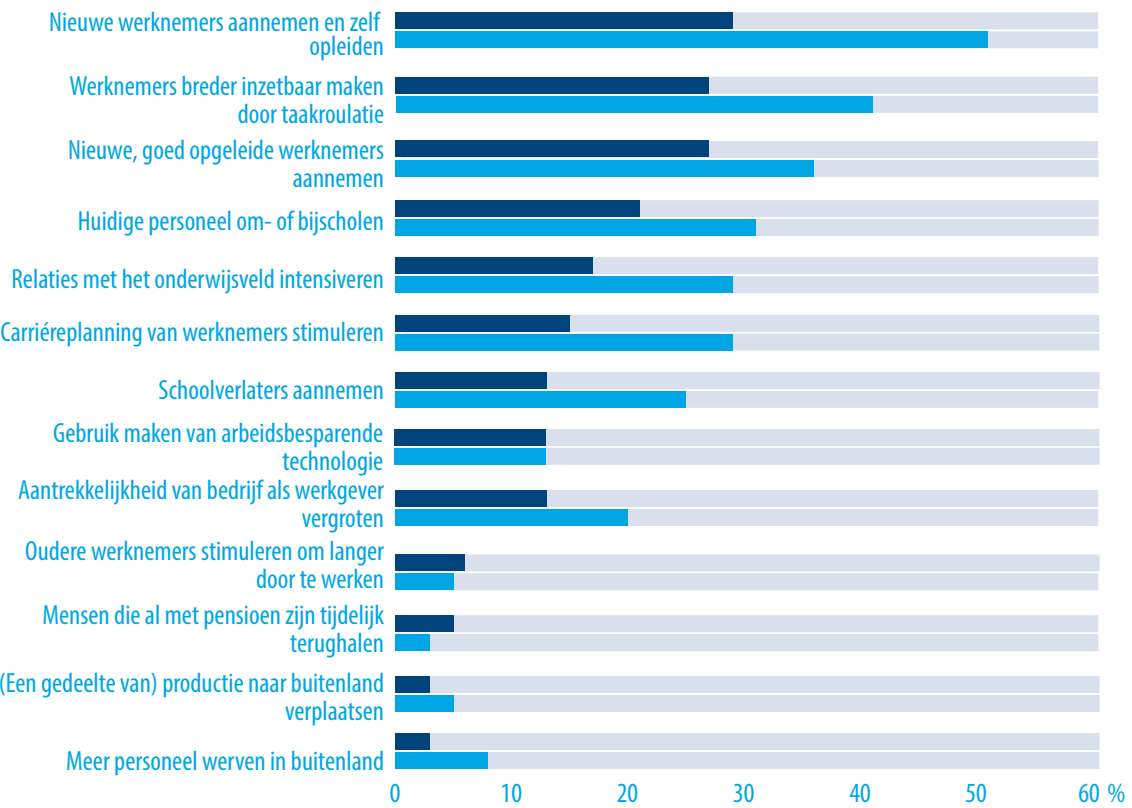

Bron: ROA, Arbeidsmarktmonitor Metalektro, 2014 
Door regelmatig te veranderen van functie kunnen werknemers worden geprikkeld om hun bestaande kennis steeds weer op andere manieren toe te passen en te blijven investeren in het ontwikkelen van nieuwe kennis en vaardigheden. $0 \mathrm{p}$ die manier kan functieroulatie op verschillende wijzen bijdragen aan de duurzame inzetbaarheid van medewerkers. Eén op de vijf metalektrobedrijven is het (helemaal) eens met de stelling dat het om de vijf jaar van functie veranderen essentieel is voor het duurzaam inzetbaar houden van hun werknemers. Daarentegen zijn bijna twee op de vijf bedrijven het (helemaal) niet eens met de stelling en staat $43 \%$ er neutraal tegenover. Grote bedrijven onderschrijven significant vaker de uitspraak dat om de 5 jaar van functie veranderen essentieel is in het kader van iemands duurzame inzetbaarheid. Grote bedrijven zullen over het algemeen over een breder palet aan functies beschikken waardoor functieroulatie of functieveranderingen gemakkelijker te realiseren zijn. Miedema Landbouwwerktuigenfabriek B.V. is een voorbeeld van een middelgroot bedrijf waarin functieroulatie wordt ingezet om brede inzetbaarheid te stimuleren. Managing director René Boeijenga geeft aan dat binnen zijn bedrijf meerdere keren per jaar aandacht wordt geschonken aan functieroulatie, hoewel dit niet in een vaste structuur is gegoten. Voor andere (kleinere) bedrijven is taakroulatie minder effectief gebleken. Redenen die hiervoor worden gegeven zijn onder meer dat werknemers vaak goed zijn in één specifieke taak of het bedienen van één specifieke machine en dat het (tijdelijk) overplaatsen naar een andere functie ertoe leidt dat de eisen op het gebied van kwaliteit en output niet meer worden gehaald.

* Bron cijfers: Arbeidsmarktmonitor Metalektro, Quickscan 2014/IV 



\section{7 \\ METALEKTRO \\ IN DE TOEKOMST}

Metalektrobedrijven zijn over het algemeen positief gestemd over de werkgelegenheidsgroei voor de eerste helft van 2015. Zo verwachten er meer bedrijven een toename in de totale werkgelegenheid en het aantal vacatures dan dat er bedrijven een afname verwachten. Dit geldt zowel voor MKB-bedrijven als grote bedrijven. Grote bedrijven met meer dan 250 werknemers zijn hierbij wel iets positiever dan MKB-bedrijven. Gedragsmatige competenties worden in de toekomst nog belangrijker dan ze al zijn en het populairste speerpunt van personeelsbeleid blijft het bevorderen van de inzetbaarheid van het personeel. 


\subsection{Bedrijven positief over verwachte ontwikkeling werkgelegenheid}

Het jaar 2014 werd gekenmerkt door een verdere verbetering van de werkgelegenheid in de sector, die al in 2013 was ingezet. Zowel in de eerste helft als in de tweede helft van het jaar was er sprake van een netto-instroom van personeel (zie Hoofdstuk 2). Ook bleek in Hoofdstuk 1 dat er voor het eerste kwartaal van 2015 nog steeds een overwicht is aan bedrijven die een groeiende werkgelegenheid verwachten. In deze en de volgende paragraaf wordt dieper ingegaan op de werkgelegenheidsverwachtingen van metalektrobedrijven.

Figuur 7.1 toont de verwachte ontwikkelingen voor de eerste helft van 2015 voor vier indicatoren: het aantal vacatures, de in- en uitstroom van personeel en de totale werkgelegenheid. Het aandeel bedrijven dat géén veranderingen verwacht is voor elke indicator het grootst. Daarnaast geldt voor alle indicatoren dat het aandeel bedrijven dat een toename verwacht groter is dan het aandeel bedrijven dat een afname verwacht. Bijna een kwart van de metalektrobedrijven verwacht in de eerste helft van 2015 een toename van de instroom van personeel, tegenover $7 \%$ van de bedrijven die een afname van de instroom verwacht. Als we kijken naar de uitstroom verwacht slechts $10 \%$ van de bedrijven een toename, terwijl $7 \%$ van de bedrijven een afname van de uitstroom verwacht. Hoewel er dus bij beide indicatoren een overwicht is van bedrijven is die een toename verwachten, is het overwicht van bedrijven dat een toename in de instroom verwacht groter dan het overwicht aan bedrijven dat een toename verwacht in de uitstroom. Het ligt daarom in de lijn der verwachting dat de netto-instroom van personeel verder toe zal nemen in de eerste helft van 2015. Dit wordt bevestigd door de indicatoren over de totale werkgelegenheidsverwachting en vacatures. Ook hier is een aanzienlijk overwicht van bedrijven dat verwacht dat de totale werkgelegenheid in de Metalektro zal toenemen.

FIGUUR 7.1 Verwachte werkgelegenheidsontwikkeling tot en met juni 2015 (\% bedrijven)

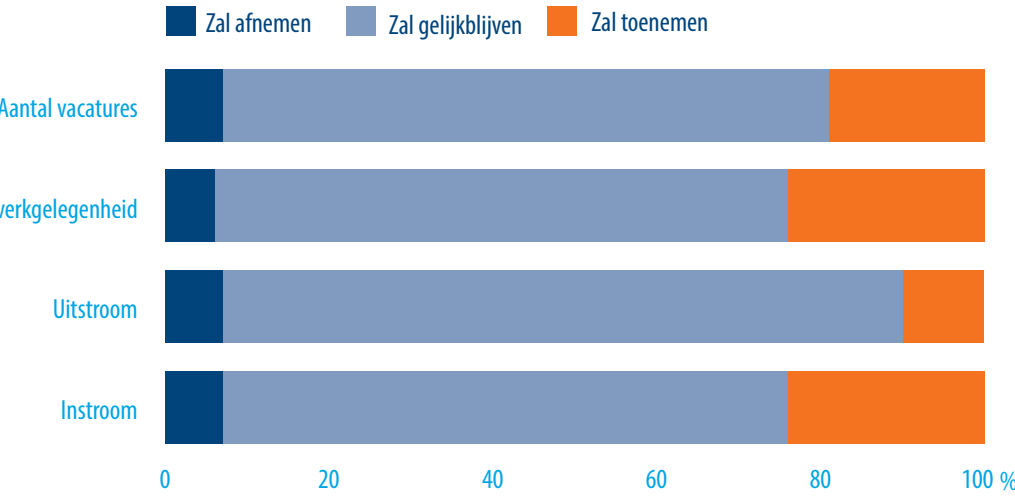

Bron: ROA, Arbeidsmarktmonitor Metalektro, 2014 


\subsection{Verwachte werkgelegenheidsontwikkeling verschilt tussen MKB-bedrijven en grote bedrijven}

Om dieper op de werkgelegenheidsverwachtingen in te gaan wordt in Figuur 7.2 een onderverdeling gemaakt naar de werkgelegenheidsverwachtingen van MKB-bedrijven ( $\leq 250$ werknemers) en grote bedrijven. Zowel MKB-bedrijven als grote bedrijven verwachten voor alle indicatoren eerder een toename dan een afname. Er is dus in beide grootteklassen een algemeen beeld van een overwicht aan bedrijven dat groeiende werkgelegenheid verwacht. Wel is het overwicht kleiner bij de MKB-bedrijven dan bij de grote bedrijven. Grote bedrijven zijn dus relatief nog positiever dan MKB-bedrijven. Opvallend is vooral dat grote bedrijven een stuk positiever zijn over de ontwikkeling van de totale werkgelegenheid en het aantal vacatures dan kleine bedrijven. Geen enkel groot bedrijf geeft aan te verwachten dat de totale werkgelegenheid of het aantal vacatures zal dalen, terwijl 7\% van de MKB-bedrijven zowel voor de totale werkgelegenheid als het aantal vacatures een daling verwacht.

FIGUUR 7.2 Verwachte werkgelegenheidsontwikkeling naar bedrijfsgrootte tot en met juni 2015 (\% bedrijven)

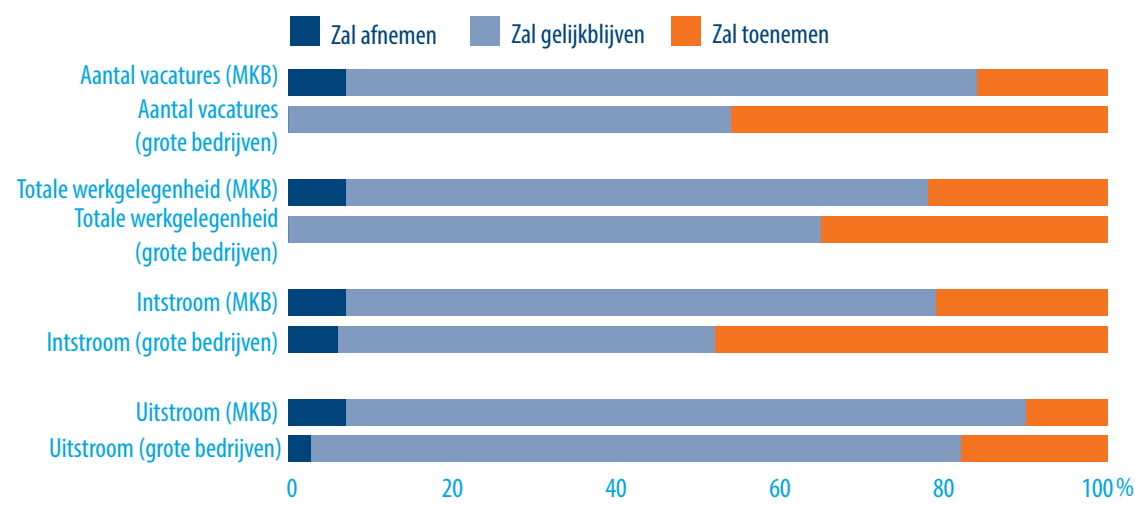

Bron: ROA, Arbeidsmarktmonitor Metalektro, 2014

\subsection{Het belang van gedragsmatige competenties voor technische functies blijft toenemen}

Aan bedrijven is gevraagd om aan te geven of ze voor de komende drie jaar veranderingen verwachten in de functies van het technisch personeel en welke veranderingen dit dan zijn. Zoals is te zien in Figuur 7.3 voorziet $16 \%$ van de bedrijven geen veranderingen in de functies van technisch personeel. Dit betekent dat de overgrote meerderheid dus wél één of meerdere veranderingen in de functies verwacht. Vergeleken met de meting uit 2013 is dit een afname van het aantal bedrijven dat veranderingen verwacht in de functies. De verandering die door bedrijven het meest genoemd wordt is het 
belangrijker worden van gedragsmatige competenties. 58\% van de bedrijven verwacht dat deze competenties belangrijker worden. Grote bedrijven geven hierbij significant vaker aan dat gedragsmatige competenties belangrijker worden dan MKB-bedrijven.

Het meer allround worden van technische functies was in 2013 nog de meest genoemde verandering, maar zakt nu naar een tweede plek. Desalniettemin wordt deze verandering nog steeds door bijna de helft (47\%) van de bedrijven genoemd. Wel lijkt deze verandering van groter belang in de regio Zuid, waar deze optie significant vaker wordt gekozen dan in de rest van het land. Twee andere veranderingen die zowel in 2013 als in 2014 vaak genoemd worden zijn het specialistischer worden van technische functies (38\%) en het vergroten van de verantwoordelijkheden van technici op een lager niveau in de organisatie (37\%). De laatste verandering werd significant vaker genoemd door grote bedrijven en bedrijven in de regio Zuid.

FIGUUR 7.3 Verwachte veranderingen in de functies van het technisch personeel in de komende 3 jaar (\% bedrijven)

2014-2018 (meting 2013)

2015-2017 (meting 2014)

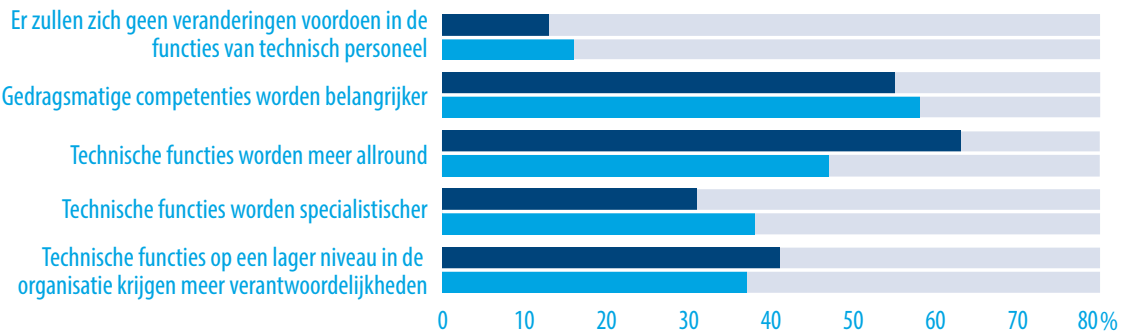

Bron: ROA, Arbeidsmarktmonitor Metalektro, 2013-2014

Noot: In 2013 werd aan bedrijven gevraagd welke veranderingen in de functies van het technisch personeel zich in de komende vijf jaar zouden voordoen. Sinds 2014 wordt naar de komende drie jaar gevraagd. Enkele antwoordopties die niet of nauwelijks werden genoemd zijn niet opgenomen in de tabel.

\subsection{Bevorderen van de inzetbaarheid van het personeel belangrijkste speerpunt voor de komende jaren}

Aan de bedrijven in de Metalektro is gevraagd om aan te geven wat de drie belangrijkste speerpunten van hun personeelsbeleid voor de komende drie jaar zijn. Figuur 7.4 toont de uitkomsten. De figuur geeft niet alleen aan wat bedrijven in 2014 als speerpunten aangaven, maar ook welke speerpunten in 2013 nog werden aangegeven. De speerpunten die in 2013 het meest werden genoemd, worden in 2014 door een nog groter percentage bedrijven genoemd, terwijl de speerpunten die in 2013 al weinig genoemd werden nu nog minder zijn genoemd. Het verschil tussen de meest- en minst genoemde 
speerpunten is daardoor groter geworden. De rangorde van meest genoemde toekomstige speerpunten is in 2014 echter vrijwel gelijk aan die van 2013. Evenals in voorgaande jaren noemt een ruime meerderheid van de bedrijven in de Metalektro (67\%) het bevorderen van de inzetbaarheid van het personeel als speerpunt van het personeelsbeleid. Hiermee blijft dit het meest voorname speerpunt van personeelsbeleid in de Metalektro.

Het bevorderen van coachend leiderschap vormt voor meer dan een kwart van de bedrijven een speerpunt voor de komende jaren. Dit speelt echter significant vaker bij grote bedrijven dan in het MKB. Van de grote bedrijven noemt $56 \%$ dit speerpunt, tegenover $24 \%$ van de MKB-bedrijven. Andere speerpunten in de top vijf van meest genoemde speerpunten zijn het verminderen van verzuim, het invoeren van leeftijdsbewust personeelsbeleid en het intensiveren van de samenwerking met onderwijsinstellingen. Ook valt het op dat steeds meer bedrijven aangeven dat leeftijdsbewust personeelsbeleid een speerpunt zal zijn in hun personeelsbeleid voor de komende jaren. Gezien het al jaren gestaag toenemende percentage oudere werknemers in de Metalektro (zie o.a. Hoofdstuk 6) is dit een positieve ontwikkeling. Voor wat betreft het intensiveren van de samenwerking met andere bedrijven en onderwijsinstellingen geldt dat dit significant vaker als speerpunt wordt genoemd door bedrijven in de regio Noord/Oost dan in de rest van het land. Het opbouwen of uitbreiden van de flexibele schil wordt daarentegen significant vaker als speerpunt genoemd in het zuiden van het land.

FIGUUR 7.4 Toekomstige speerpunten personeelsbeleid (\% bedrijven)

2014-2018 (meting 2013)

2015-2017 (meting 2014)

Bevorderen van de inzetbaarheid van het personeel

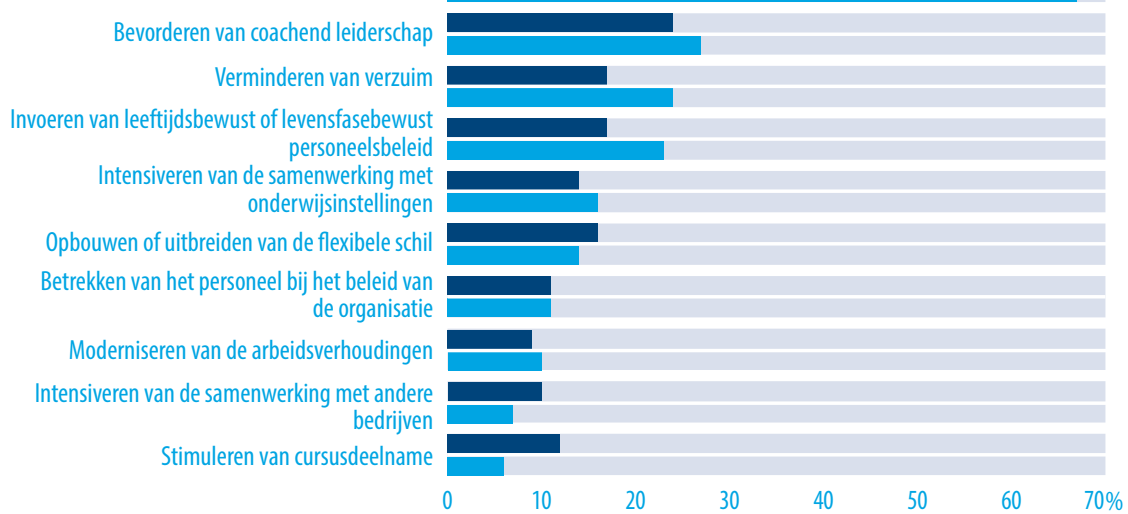

Bron: ROA, Arbeidsmarktmonitor Metalektro, 2013-2014

Noot: In de figuur zijn alleen de speerpunten opgenomen die voor ten minste één van de jaren door minimaal 10\% van de bedrijven zijn genoemd. Speerpunten die door minder dan 10\% genoemd werden zijn: voorkomen van vroegtijdige uitstroom, flexibele werktijden invoeren, loopbaanbeleid implementeren, verminderen van werkdruk en een prestatiebeloning en/of flexibele beloning invoeren. In 2013 werd aan bedrijven gevraagd wat hun speerpunten voor de komende vijf jaar waren. Sinds 2014 wordt gevraagd naar speerpunten voor de komende drie jaar. 
Opvallend is dat het aandeel bedrijven dat vermindering van verzuim tot de drie belangrijkste speerpunten rekent in 2014 is toegenomen. Dit speerpunt werd namelijk tussen 2011 en 2013 door steeds minder bedrijven genoemd. Dit is te zien in Figuur 7.5, welke voor de afgelopen negen jaar het aandeel bedrijven weergeeft dat het verminderen van verzuim als speerpunt noemde. De figuur toont ook de omzetontwikkeling in de sector. Er lijkt sprake van een positief verband tussen het aandeel bedrijven dat het verminderen van verzuim als speerpunt noemt en de ontwikkeling van de omzet. De periode van omzetgroei vóór 2009 ging gepaard met een toenemend aandeel bedrijven dat verminderen van verzuim als speerpunt noemde, terwijl de omzetdaling van 2009 werd gevolgd door een sterke afname in het speerpunt verminderen van verzuim. Deze ontwikkeling zette door tot in 2010. De opleving van de omzet in 2010 en 2011 leidde met enige vertraging in 2011 tot een toename in het aandeel bedrijven dat het verminderen van verzuim als speerpunt noemde. Gelijktijdig met de omzetdaling in 2012 nam dit speerpunt vervolgens echter weer af in belang. De positieve omzetontwikkeling vanaf 2013 leidde in 2014 weer tot een toename in het aandeel bedrijven dat verminderen van verzuim als speerpunt noemde. In de periode 2006-2014, waarin zowel crisisjaren als hersteljaren zaten, valt dus op dat omzetdalingen meteen leiden tot een kleiner aandeel bedrijven dat vermindering van verzuim als speerpunt noemt. Perioden van groei daarentegen leiden tot een toename in het aandeel bedrijven dat de vermindering van verzuim als speerpunt noemt, zij het met enige vertraging. Als het goed gaat met de omzet en de productiecapaciteit beter benut wordt zijn alle hens aan dek nodig en ligt er meer nadruk op het voorkomen van verzuim.

FIGUUR 7.5 Verminderen van verzuim als speerpunt (\% bedrijven) en omzet Metalektro over tijd

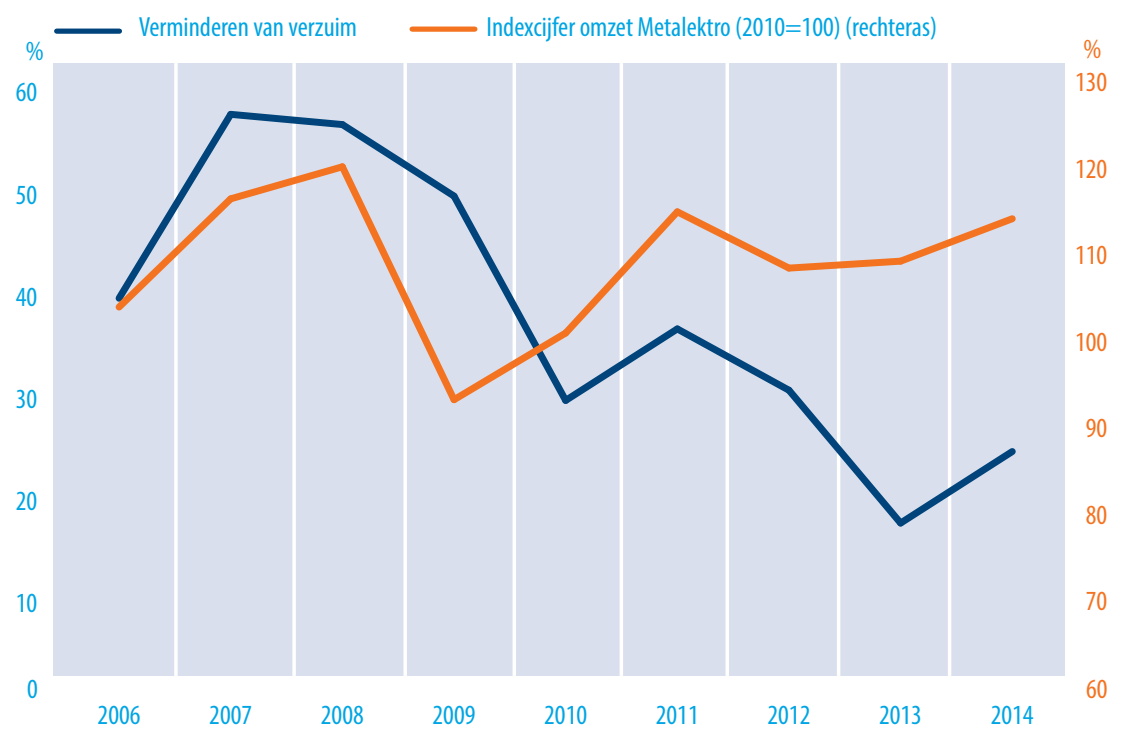

Bron: ROA, Arbeidsmarktmonitor Metalektro, 2006-2014; CBS Nijverheidsstatistiek, 2006-2014 
Ardagh in Deventer probeert zijn werknemers over te halen om gezonder te leven. Motiveren en stimuleren van gezond gedrag in plaats van met het vingertje wijzen staat hierbij centraal, aldus Herman van der Donk, HR manager. Als voorbeeld noemt hij de kroket, die in de kantine met opzet wat hoger geprijsd wordt dan gezondere (snack)opties. Door gezond gedrag goedkoper te maken en ongezond gedrag duurder te maken probeert Ardagh gezonder gedrag bij werknemers te bewerkstelligen. Een tweede voorbeeld hiervan is het stimuleren van bezoekjes aan de sportschool. Voor werknemers die minimaal één keer per week naar de sportschool gaan betaalt Ardagh het abonnement. Daarnaast biedt Ardagh zijn werknemers een gratis stoppen met roken cursus aan. Deze sportschooloptie en stoppen met roken cursus zijn echter niet vrijblijvend. Als werknemers minder dan één keer per week naar de sportschool gaan of als werknemers na het volgen van de stoppen met roken cursus blijven roken moeten ze de sportschool en/of de stoppen met roken cursus zelf vergoeden. Het stimuleren van gezond gedrag heeft niet enkel grote voordelen voor de werknemer. Van der Donk wijst op het feit dat Ardagh er de afgelopen jaren in is geslaagd om het ziekteverzuim drastisch te reduceren van $10 \%$ naar $\pm 3 \%-4 \%$. Om het ziekteverzuim nog verder te verlagen zal de focus in de toekomst nóg meer komen te liggen op preventieve in plaats van curatieve maatregelen.

De grootste stap die Ardagh volgens Van der Donk heeft genomen om het ziekteverzuim drastisch te reduceren, is het serieus nemen van werknemers. Als voorbeeld legt Van der Donk uit wat Ardagh doet met werknemers die vaak en/of lang ziek zijn: "In plaats van een controleur te sturen proberen we mee te denken met de werknemer en proberen we samen met hem zijn probleem op te lossen. We schenken hem aandacht en nemen hem serieus. 0ok hebben we bijvoorbeeld elke donderdagmiddag een psycholoog die op het bedrijf een spreekuur houdt. Werknemers maken hier in toenemende mate gebruik van en dit voorkomt dat deze werknemers de problemen laten oplopen en later maanden lang ziek thuis zitten". Het serieus nemen en aandacht schenken aan medewerkers is volgens Van der Donk dus de basis bij het reduceren van ziekteverzuim. "We gaan zeker niet een discussie met een werknemer in met de opmerking 'je bent niet ziek!', maar we proberen juist te achterhalen wat de bron van het probleem is. 0ok proberen we samen met de werknemer goed te kijken waar hij nog wél toe in staat is. Als iemand vaak last heeft van hoofdpijn proberen we niet alleen de bron van die hoofdpijn te achterhalen, maar ook te kijken naar de vraag welke werkzaamheden hij nog wel kan verrichten als hij last heeft van deze hoofdpijn. Als de hoofdpijn niet minder erg wordt als de werknemer thuis zit, kunnen we immers net zo goed kijken wat hij wel nog zou kunnen doen".

\subsection{Functioneringsgesprek populairste instrument voor realiseren speerpunten}

Figuur 7.6 toont de HR-instrumenten waarmee bedrijven de toekomstige speerpunten uit de vorige paragraaf willen realiseren. De rangorde van meest gekozen HR-instrumenten lijkt sterk op die van voorgaande jaren. Net als in voorgaande jaren blijkt het functioneringsgesprek veruit het populairste instrument om de HR-speerpunten te bereiken. Hoewel het belang hiervan iets lijkt te zijn afgenomen, geeft nog steeds $64 \%$ van de bedrijven aan functioneringsgesprekken te voeren met het personeel teneinde de toekomstige speerpunten te realiseren. Naast het voeren van functioneringsgesprekken maken het voeren van scholingsgesprekken, het opstellen van een persoonlijk ontwik- 
kelingsplan (POP), het voeren van werkoverleg en beoordelingsgesprekken ook onderdeel uit van de top vijf meest gebruikte instrumenten. Al deze HR-instrumenten worden door meer dan $40 \%$ van de bedrijven toegepast. Opvallend is de sterke toename van $24 \%$ naar $39 \%$ in het aandeel bedrijven dat functieroulatie noemt als toekomstig speerpunt. Zowel het werkoverleg als het beoordelingsgesprek worden tussen 2012 en 2014 steeds minder ingezet met betrekking tot het bereiken van HR speerpunten. Daarentegen kan het instrument loopbaanplanning, waarvoor in 2012 en 2013 nog een sterke afname te zien was, weer op een gestegen belangstelling rekenen. Opvallend is dat loopbaanplanning significant vaker wordt genoemd door grote bedrijven dan door MKB-bedrijven. Ook het gebruik van een competentie- of vaardighedenmatrix komt vaker voor onder grote bedrijven dan in het MKB. Onder MKB-bedrijven geniet daarentegen het werkoverleg grotere populariteit dan onder grote bedrijven.

FIGUUR 7.6 HR-instrumenten t.b.v. het bereiken van toekomstige speerpunten (\% bedrijven)

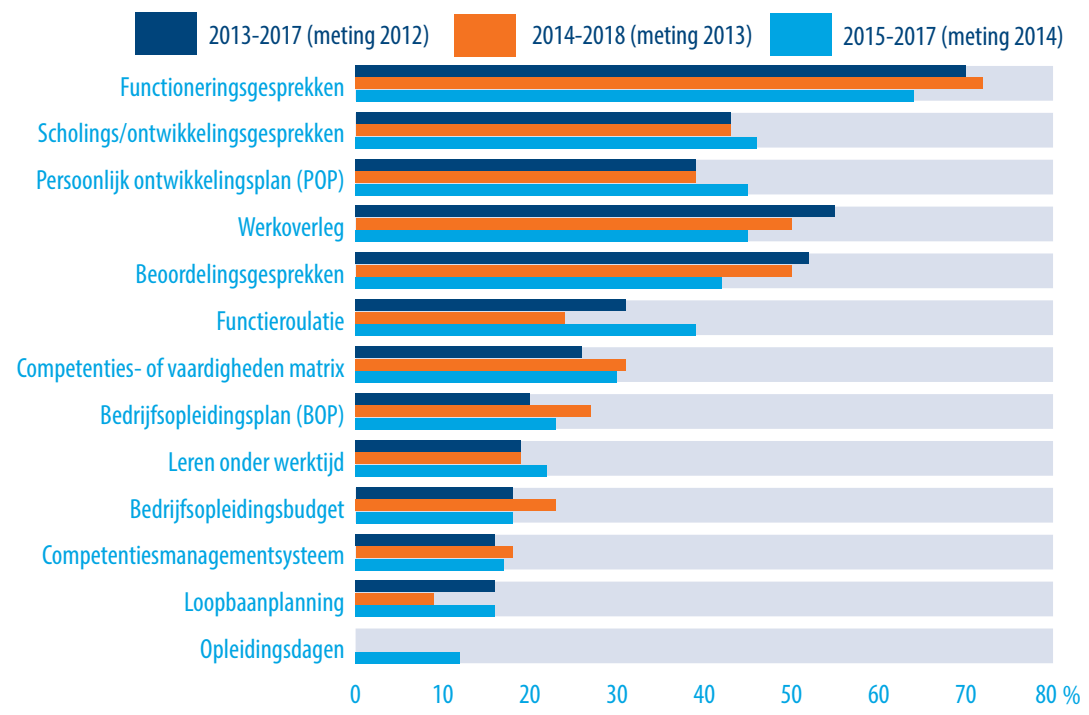

Bron: ROA, Arbeidsmarktmonitor Metalektro, 2011-2014

Noot: In de figuur zijn alleen de instrumenten opgenomen die door minimaal $10 \%$ van de bedrijven zijn genoemd. In 2012 en 2013 werd aan bedrijven gevraagd welke HR-instrumenten zij de komende vijf jaar zouden inzetten voor het realiseren van speerpunten. Sinds 2014 wordt gevraagd welke HR-instrumenten de komende drie jaar zouden worden ingezet.

In de vragenlijst van 2014 werden op basis van het 'Protocol CAO Metalektro 2013/2015'19 enkele nieuwe antwoordopties toegevoegd. Deze toegevoegde HR-instrumenten zijn: de persoonlijke inzetbaarheidsscan, andere werkpatronen, opleidingsdagen en de loopbaancheck. Slechts één van deze vier instrumenten is daadwerkelijk te zien in Figuur 7.6, namelijk de opleidingsdagen. Dit is de enige van de nieuwe antwoordmoge-

19 http://www.ao-metalektro.nl/images/pdf/Protocol.pdf 
lijkheden die hoger scoorde dan 10\%. De relatief lage score voor de vier toegevoegde HR-instrumenten is opvallend gezien het belang van deze instrumenten expliciet aan bod komt in het 'Protocol CAO Metalektro 2013/2015'. Desalniettemin zijn het relatief nieuwe instrumenten die mogelijk tijd nodig hebben om een plek in het scala van HR-instrumenten te veroveren. Het is interessant om bij te houden hoe het gebruik van deze instrumenten voor het bereiken van HR speerpunten in de komende jaren ontwikkelt.

\subsection{Knelpunten van speerpunten}

Bij het realiseren van de genoemde speerpunten verwacht $33 \%$ van de bedrijven geen problemen. In 2013 verwachtte $26 \%$ van de bedrijven geen knelpunten. Er lijkt dus sprake van een verbetering ten opzichte van 2013. Toch verwacht dus twee derde van de bedrijven wel tegen knelpunten op te lopen bij het realiseren van toekomstige speerpunten. De meest genoemde knelpunten zijn in Figuur 7.7 gegeven. Evenals in voorgaande jaren hebben de verwachte knelpunten vooral betrekking op het personeel en minder op het niveau van de organisatie. Metalektrobedrijven verwachten bijvoorbeeld dat het personeel moeilijk om zal kunnen gaan met veranderingen (genoemd door $39 \%$ van de bedrijven). Tevens blijkt dat iets meer dan een kwart (26\%) van de bedrijven verwacht dat het personeel onvoldoende bereid is om in zichzelf te investeren en een op de vijf bedrijven geeft aan dat de flexibiliteit van het personeel tekortschiet. Ook een te laag kennisniveau van het personeel en onvoldoende motivatie om mee te gaan met veranderingen werden genoemd (aangegeven door $16 \%$, respectievelijk $12 \%$ ). Knelpunten op organisatorisch niveau - zoals onvoldoende medewerking van de direct leidinggevende, onvoldoende budget of onvoldoende zicht op de competenties van het personeel - worden beduidend minder vaak genoemd.

Het is zorgwekkend dat het percentage bedrijven dat aangeeft dat hun personeel onvoldoende bereid is om in zichzelf te investeren de laatste jaren sterk toeneemt. Dit temeer omdat er door de toenemende complexiteit van het werk steeds meer van medewerkers wordt gevraagd. Daarentegen daalt sinds 2013 het percentage bedrijven dat aangeeft dat de flexibiliteit van het personeel tekort schiet. Ook de omvang van budgetten wordt steeds minder vaak als knelpunt genoemd. Het feit dat bedrijven minder vaak aangeven dat onvoldoende budget een knelpunt is heeft waarschijnlijk te maken met de verbetering in de gemiddelde (bedrijfs)economische situatie. Ander positief nieuws is dat het kennisniveau van het personeel, alsmede de bereidheid om mee te gaan met veranderingen, in 2014 minder vaak als knelpunt worden gezien. 
FIGUUR 7.7 Verwachte knelpunten bij het realiseren van toekomstige speerpunten (\% bedrijven)

Er worden geen knelpunten verwacht

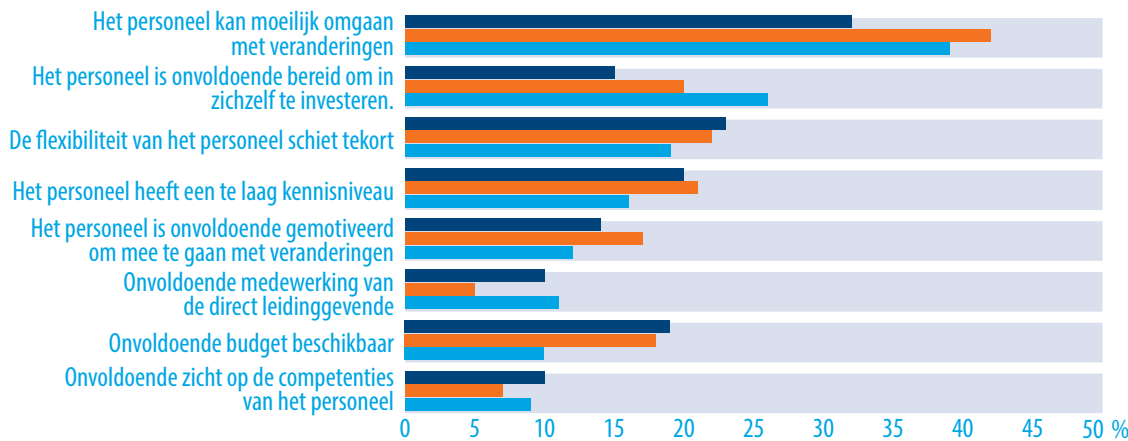

Bron: ROA, Arbeidsmarktmonitor Metalektro, 2011-2014

Noot: In de figuur zijn alleen de knelpunten opgenomen die door minimaal $10 \%$ van de bedrijven zijn genoemd. In 2013 werd aan bedrijven gevraagd welke knelpunten zich in de komende vijf jaar zullen voordoen. In 2014 werd gevraagd welke knelpunten zich in de komende drie jaar voor zullen doen.

Met betrekking tot deze knelpunten zijn er geen significante verschillen tussen MKB-bedrijven en grote bedrijven. Wel zijn er enkele verschillen tussen de regios Zuid, West en Noord/Oost. Zo worden er in de regio Noord/Oost significant vaker knelpunten verwacht. Ook geven bedrijven in deze regio significant vaker aan dat het personeel over een te laag kennisniveau beschikt. Indien we terugkijken naar de toekomstige speerpunten die bedrijven noemen, valt op dat het percentage bedrijven dat het intensiveren van de samenwerking met onderwijsinstellingen noemt in de regio Noord/Oost significant hoger is dan in de rest van het land. Het zou kunnen dat het gerapporteerde lagere kennisniveau van het personeel in deze regio de reden is voor het veelvuldig kiezen van dit speerpunt. Positief hierbij is het feit dat het personeel in deze regio volgens de bedrijven in hogere mate bereid is om in zichzelf te investeren dan in de rest van het land. Dit biedt mogelijkheden om het kennisniveau in deze regio te verbeteren. Bedrijven in de regio Zuid geven significant vaker aan dat een gebrek aan flexibiliteit van het personeel een knelpunt is. 


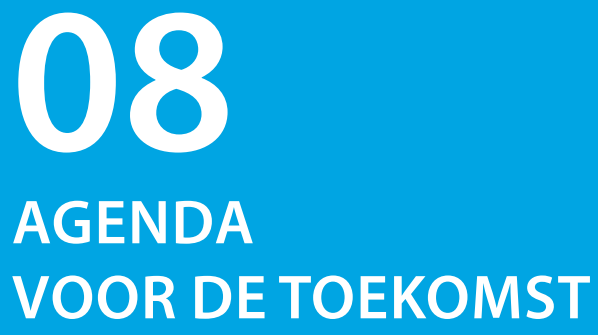

Eind 2014 heeft de Nederlandse maakindustrie de Actieagenda Smart Industry gelanceerd. 'Smart industry' is daarbij de verzamelnaam die een aantal trends samenvat die al enige tijd gaande zijn in de Metalektro en waarvan verwacht kan worden dat ze de komende jaren verder door zullen zetten. Deze trends zijn onder meer de snelle technologische ontwikkeling in bijvoorbeeld robotica en sensortechnologie, de toenemende samenwerking van bedrijven in ketens en netwerken en de alsmaar stijgende eisen die mede hierdoor aan het personeel in de Metalektro gesteld worden. De beweging naar een 'smart industry', werkt als een stuwende kracht onder de toenemende vraag naar hoger opgeleiden, PROFI skills en brede inzetbaarheid. Human capital is hiermee de motor van de sector geworden. Voor de bedrijven is het essentieel dat hun personeel zo goed mogelijk mee komt, en mee wordt genomen, met deze beweging richting een 'smart industry. Dit geldt vanzelfsprekend ook voor de medewerkers zelf. Tot op heden is deze brede inzetbaarheid echter een punt waarop nog veel bedrijven knelpunten ervaren. Bedrijven geven bijvoorbeeld aan dat het verbeteren van de inzetbaarheid nogal eens belemmerd wordt doordat medewerkers vaak moeilijk kunnen omgaan met veranderingen of onvoldoende bereid zijn in zichzelf te investeren. Ook wervingsproblemen en de vergrijzing kunnen een knelpunt vormen in de beweging naar een 'smart industry'. Metalektrobedrijven proberen hun werknemers op verschillende manieren te faciliteren en motiveren om zich te blijven ontwikkelen. Zo proberen steeds meer bedrijven een leerrijke werkomgeving te creëren en hebben steeds meer bedrijven aandacht voor duurzame inzetbaarheid en vervangingsproblemen. Daarbij komt het initiatief voor het volgen van trainingen steeds vaker bij de HR afdeling te liggen. Momenteel biedt bijna 90\% van de metalektrobedrijven zijn medewerkers trainingen aan in vaktechnische kennis en vaardigheden. De investeringen in trainingen en opleidingen namen in 2014 licht toe, net als de aandacht voor de ontwikkeling van 'soft skills', maar beide blijven achter bij wat nodig lijkt te zijn voor de ontwikkeling tot een 'smart industry.' Ook zien we dat bedrijven doorgaans veel minder aandacht besteden aan het op peil houden van de kennis en vaardigheden van medewerkers in de flexibele schil dan bij de medewerkers die in vaste dienst zijn, hoewel de verschillen de afgelopen twee jaar wel kleiner zijn geworden. Door de cruciale rol die het human capital speelt in de beweging naar een 'smart industry' zal de rol van de HR afdeling de komende jaren alleen nog maar toenemen en zal de concurrentiekracht van de bedrijven in de Metalektro in toenemende mate worden bepaald door de professionaliteit van het gevoerde HR-beleid. 


\subsection{Positieve economische ontwikkelingen en een lichte werkgelegenheidsgroei}

In de Agenda voor de Toekomst van vorig jaar constateerden we dat de sector in 2013 door de bank genomen een positieve ontwikkeling had doorgemaakt. De omzetgroei kroop uit het dal en schreef aan het eind van dat jaar weer zwarte cijfers, wat gepaard ging met een sterk groeiende flexibele schil. Daarnaast stabiliseerden, na jaren van daling, de gemiddelde uitgaven van metalektrobedrijven aan scholing en training en nam het aantal bedrijven met vacatures toe. Blijvende scherpte was, en is, echter geboden ten aanzien van een aantal knelpunten die - juist bij een aantrekkende economie - sneller tot uitdrukking kunnen komen, zoals een hoge vervangingsvraag en een sterke toename van het overwerk.

De opleving die in 2013 inzette heeft zich in 2014 sterk doorgezet (Figuur 1.1). De omzetgroei was in alle kwartalen positief. Deze goede bedrijfseconomische ontwikkeling ging gepaard met een lichte groei van de werkgelegenheid (Tabel 1.1). De flexibele schil is in 2014 weer verder gegroeid. Vooral in de eerste helft van het jaar was er een sterke toename van het aantal tijdelijke contracten. In de tweede helft van het jaar nam de omvang van de flexibele schil weer wat af; vooral door een daling van het aantal tijdelijke contracten (Figuur 2.5). Gezien het feit dat de totale werkgelegenheid in de Metalektro in 2014 licht is gegroeid, is het niet ondenkbaar dat de afname van het aantal tijdelijke contracten veroorzaakt is doordat een deel hiervan is omgezet in vaste aanstellingen. Signalen van bedrijven uit de sector bevestigen dit.

Eind 2014 heeft de Nederlandse maakindustrie - in navolging van het Duitse programma Industry 4.0 - de Actieagenda Smart Industry gelanceerd. In deze Agenda voor de Toekomst zal de zich snel voortzettende beweging van de Metalektro in de richting een 'smart industry' en de samenhang hiervan met HR ('human capital') beleid centraal staan. 'Smart industry' is daarbij de verzamelnaam die een aantal trends samenvat die al enige tijd gaande zijn in de Metalektro en waarvan verwacht kan worden dat ze de komende jaren verder door zullen zetten. In paragraaf 8.2 zetten we deze trends, die vooral betrekking hebben op het vereiste human capital in de sector, op een rij. In paragraaf 8.3 gaan we in op de problemen en uitdagingen die metalektrobedrijven in hun human capital beleid ervaren, waarna we in paragraaf 8.4 de door de metalektrobedrijven ingezette oplossingsstrategieën bespreken. In paragraaf 8.5 trekken we conclusies en presenteren enkele concrete handvatten voor het toekomstige human capital beleid.

\subsection{Eisen aan personeel worden hoger: de sector beweegt naar een 'smart industry'}

Uit verschillende indicatoren blijkt dat de eisen die aan het personeel in de Metalektro gesteld worden nog altijd omhoog gaan; de upgrading van het opleidingsniveau van de medewerkers gaat onverminderd voort. Het aandeel hoger opgeleiden in de sector (minimaal HBO niveau) is op recordhoogte aanbeland, terwijl het aandeel lager opgeleiden (VMBO of lager) steeds verder afneemt (Figuur 1.6). Daarnaast geven de bedrijven 
wederom aan dat gedragsmatige competenties nog belangrijker worden (Figuur 7.3). Dit bevestigt het toenemende belang van 'soft skills', die eerder door de metalektrobedrijven werden getypeerd als de PROFI competenties:

- Probleemoplossend vermogen

- Relatie met klanten

- Omgaan met veranderingen

- Flexibiliteit

- Initiatief

De behoefte aan medewerkers die beschikken over PROFI skills wordt nog versterkt door de grote behoefte om medewerkers variabel in te kunnen zetten. Deze variabele inzet van medewerkers is de door metalektrobedrijven meest verwachte organisatorische verandering voor de komende drie jaar (Figuur 5.1). Van het personeel wordt dan ook steeds meer verwacht dat ze breed inzetbaar zijn. Niet alleen voor het opvangen van schommelingen in de bedrijfsdrukte, maar bij bijna de helft van de metalektrobedrijven ook vanwege product- en procesvernieuwingen (Figuur 5.5). De inzetbaarheid van het personeel is dan ook met afstand het belangrijkste speerpunt van HR beleid voor de komende jaren (Figuur 7.4).

De beweging naar een 'smart industry', werkt als een stuwende kracht onder de toenemende vraag naar hoger opgeleiden, PROFI skills en brede inzetbaarheid. Human capital is hiermee de motor van de sector geworden.

Deze stijgende vraag naar hoger opgeleiden, soft skills en brede inzetbaarheid staan niet los van elkaar en moeten gezien worden in het kader van een bredere ontwikkeling. Een combinatie van snelle technologische ontwikkeling in robotica en sensortechnologie en de komende jaren waarschijnlijk ook in 3D-printen, maakt dat de Metalektro zich momenteel in razend tempo ontwikkelt. De bedrijven maken meer en meer deel uit van samenwerkende ketens en netwerken waarin complexe en kennisintensieve producten worden gemaakt, die over de hele wereld worden afgezet, met veel oog voor de specifieke wensen van de afnemers. In deze ketens is er steeds meer sprake van co-creatie en coproductie waarbij innovatieve gespecialiseerde MKB-bedrijven een grote rol spelen. Dit wordt onderstreept in Figuur 5.9, waarin de samenwerking met klanten en samenwerking binnen de sector de twee belangrijkste (toekomstige) vormen van samenwerking blijken te zijn voor de metalektrobedrijven.

Al deze ontwikkelingen, die samengevat kunnen worden als de beweging naar een 'smart industry', werken als een stuwende kracht onder de toenemende vraag naar hoger opgeleiden, soft skills en brede inzetbaarheid. Human capital is hiermee de motor van de sector geworden. Aangenomen mag worden dat de ontwikkeling van een 'smart industry' een additionele impuls zal geven aan de al langer lopende hboisering van de werkgelegenheid in de sector alsook aan een blijvend sterke vraag naar 
PROFI skills en een brede inzetbaarheid van de medewerkers. Uit de derde Quickscan van 2014 bleek bijvoorbeeld dat nu al 29\% van de metalektrobedrijven verwacht dat banen op MBO-niveau 1 en 2 in de toekomst vrijwel zullen verdwijnen, terwijl 14\% van de bedrijven verwacht dat een meerderheid van de technici in de toekomst minimaal een HBO-diploma heeft.20

\subsection{Welke knelpunten en uitdagingen ervaren bedrijven bij de ontwikkeling van hun personeel?}

Voor de bedrijven is het essentieel dat hun personeel zo goed mogelijk mee komt, en mee wordt genomen, met deze beweging richting een 'smart industry'. Dit geldt vanzelfsprekend ook voor de medewerkers zelf. Tot op heden is dit echter een punt waarop nog veel bedrijven knelpunten ervaren. Zo geeft een derde van de metalektrobedrijven aan dat ze meer behoefte hebben aan breed inzetbare uitvoerende technici dan ze momenteel beschikbaar hebben (Figuur 5.4). Ook geven ze aan dat het verbeteren van de inzetbaarheid nogal eens belemmerd wordt doordat medewerkers vaak moeilijk kunnen omgaan met veranderingen. Bovendien geven steeds meer bedrijven aan dat hun personeel onvoldoende bereid is in zichzelf te investeren (Figuur 7.7). Daarnaast ervaren steeds meer bedrijven problemen bij de werving van engineering en R\&D personeel (Figuur 3.10), wat bij uitstek één van de meest human capital gedreven functiecategorieën is. Deze wervingsproblemen leiden vaak tot een toenemende werkdruk en kunnen ook een belemmering vormen voor innovatie (Tabel 3.1). Dit is een belangrijk punt van zorg omdat human capital gedreven innovatie van cruciaal belang is voor een sector die zich ontwikkelt tot een 'smart industry'. Daar komt nog bij dat er in de Metalektro relatief veel ouderen en weinig jongeren werken (Figuur 6.2). Deze vergrijzing en ontgroening van het personeel spelen de sector parten en vormt de komende jaren een belangrijke uitdaging voor het HR beleid van de metalektrobedrijven. Tot slot is de flexibele schil de laatste jaren zeer sterk gegroeid, van $14 \%$ van de totale werkgelegenheid in januari 2013 tot 37\% in januari 2015 (Figuur 2.5). Met zoveel medewerkers in de flexibele schil is het nog belangrijker dan ooit dat deze medewerkers goed opgeleid zijn en blijven beschikken over een up-to-date competentieprofiel.

\subsection{Hoe faciliteren en motiveren bedrijven hun werknemers om zich te ontwikkelen?}

De Metalektro is van oudsher een van de sectoren waarin vakkennis sneller veroudert dan in veel andere sectoren. Onderzoek laat namelijk zien dat kennis in het vakgebied van natuur en techniek sneller veroudert dan in andere vakgebieden.$^{21}$ De veel kortere

20 Gerards, R. (2014). Arbeidsmarktmonitor Metalektro Quickscan 2014-3. Maastricht: ROA. http://www.ao-metalektro.nl/images/pdf/quickscans/Quickscan-derde-kwartaal-2014.pdf

21 A. de Grip \& J. van Loo (2002) "The Economics of Skills Obsolescence: A Review." In: A. de Grip, J. van Loo \& K. Mayhew (eds.). The Economics of Skills Obsolescence,. Research in Labor Economics, Vol 21,. Amsterdam/ Boston: JAI Press, p.1-26. 
'halfwaardetijd' van technische kennis is een logisch gevolg van de snelheid waarmee technologische en organisatorische innovaties in de sector worden geïmplementeerd. Het is dan ook goed dat bijna 90\% van de metalektrobedrijven zijn medewerkers trainingen aanbiedt in vaktechnische kennis en vaardigheden. Er is dus veel aandacht voor de vaktechnische verdieping en verbreding, die een belangrijke pijler vormt in de beweging naar een 'smart industry'. Om de knelpunten die in de vorige paragraaf beschreven staan te verhelpen is er echter meer nodig dan vakinhoudelijke training. Dit roept de vraag op hoe metalektrobedrijven met hun HR beleid hun personeel faciliteren en motiveren om mee te gaan met veranderingen, om meer PROFI skills onder de knie te krijgen en om breder inzetbaar te worden.

\section{De investeringen in training en opleiding nemen sinds kort voorzichtig toe, maar kunnen nog aanzienlijk beter}

Op een aantal aspecten van human capital ontwikkeling tonen metalektrobedrijven in 2014 ontwikkelingen die ten opzichte van het recente verleden veelbelovend lijken, maar op de keper beschouwd nog altijd achter blijven bij wat nodig lijkt te zijn voor de ontwikkeling tot een 'smart industry'.

Ten eerste is het positief dat de opleidingsuitgaven als percentage van de loonsom in 2014 voor het eerst sinds 2009 weer zijn gestegen, van 1,3\% naar 1,6\% (Figuur 4.1). Ook het gemiddeld aantal dagen dat aan opleidingen wordt besteed is gestegen van 2,5 naar 3,4 dag per technische werknemer. Toch liggen vooral de opleidingsuitgaven nog altijd op een relatief laag niveau. Deze waren in 2004 nog 3\% van de loonsom. Dat is bijna twee keer zo hoog als in 2014.

Ten tweede was er in 2014 in meer bedrijven aandacht voor de ontwikkeling van soft skills. Het percentage bedrijven dat medewerkers trainde op gebied van communicatieve vaardigheden steeg van 19\% in 2013 naar $30 \%$ in 2014; voor training in commerciële vaardigheden steeg dit van $14 \%$ naar $17 \%$ en voor trainingen gericht op plannen en organiseren van $10 \%$ naar $14 \%$ (Figuur 4.5). Deze bescheiden stijgingen nemen echter niet weg dat er in de grote meerderheid van metalektrobedrijven nog te weinig aandacht is voor de ontwikkeling van de PROFI skills.

Wel zien we dat het percentage metalektrobedrijven dat actief probeert een leerrijke werkomgeving te creëren in 2014 duidelijk is toegenomen tot $26 \%$ van alle bedrijven (Figuur 4.4). Het creëren van een leerrijke werkomgeving stimuleert het informele leren op het werk, wat cruciaal is voor het optimaal presteren van een 'smart industry'. Daarbij gaat het om zowel 'learning by doing' als om de kennisoverdracht tussen medewerkers op de werkvloer. De ROA Leven Lang Leren Enquête $2013^{22}$ laat zien dat informeel leren tijdens het werk inmiddels al $96 \%$ van de totale tijd beslaat die werkenden in Nederland aan leeractiviteiten besteden.

22 L. Borghans, D. Fouarge, A. de Grip \& Jesper van Thor (2014). Werken en leren in Nederland. Maastricht: ROA. 
Tot slot zien we dat bedrijven doorgaans veel minder aandacht besteden aan het op peil houden van de kennis en vaardigheden van medewerkers in de flexibele schil dan bij de medewerkers die in vaste dienst zijn, hoewel de verschillen de afgelopen twee jaar wel kleiner zijn geworden. Van het technisch personeel in vaste dienst heeft bijna $50 \%$ het afgelopen jaar minstens één cursus of training gevolgd; onder de medewerkers met een tijdelijk contract is dat met $45 \%$ iets lager, maar bij het ingeleende technisch personeel is de trainingsdeelname slechts $29 \%$ (Figuur 4.2). Vanuit bedrijfsperspectief is het begrijpelijk dat flexwerkers minder training volgen. Vooral ingeleende krachten zijn doorgaans slechts korte tijd bij het bedrijf werkzaam. Gezien de snelle halfwaardetijd van technische kennis en verschuivende competentie-eisen, zal een gebrek aan training echter na verloop van tijd de duurzame inzetbaarheid van deze medewerkers aantasten. Hierdoor zullen bedrijven bij een krappere arbeidsmarkt worden geconfronteerd met een flexibele schil die niet langer adequaat kan worden ingezet omdat de tijdelijke krachten vaardigheden te kort komen. Zeker gezien de grote omvang die de flexibele schil bij tijden aanneemt, zoals de piek van $43 \%$ in juli 2014, is het van vitaal belang dat al deze mensen optimaal inzetbaar blijven.

\section{Initiatief voor het volgen van training ligt steeds vaker bij HR afdeling}

Uit Figuur 4.3 blijkt dat er de afgelopen jaren een zeer lichte stijging heeft plaatsgevonden in het aandeel van de trainingen dat werd gevolgd op eigen initiatief van werknemers. Ook nam het aandeel van de trainingen dat op gezamenlijk initiatief van werknemer en werkgever werd gevolgd licht toe. De grootste stijging in het initiatief voor trainingen en cursussen van het technisch personeel is echter duidelijk te zien bij de HR afdeling. Al deze verschuivingen gaan vooral ten koste van trainingen die puur op initiatief van de direct leidinggevende worden gevolgd. Uit deze verschuivingen blijkt enerzijds dat de maatregelen, die de afgelopen jaren zijn genomen om technisch personeel bij hun eigen opleiding en ontwikkeling te betrekken, langzaam vruchten beginnen af te werpen. Anderzijds duidt met name de toename van het initiatief voor het opleiden van medewerkers vanuit de HR afdeling op een gegroeide rol van deze afdeling bij het human capital beleid van het bedrijf.

\section{Steeds meer aandacht voor duurzame inzetbaarheid en vervangingsproblemen}

Ondanks de nog altijd stijgende gemiddelde leeftijd van de werkenden in de metalektrobedrijven en de scheve leeftijdsverdeling, verwachten bedrijven minder vervangingsproblemen dan in de voorgaande jaren (Figuur 6.4). Voor een deel is dit het gevolg van het feit dat vrij komende arbeidsplaatsen niet meer worden ingevuld doordat werkzaamheden worden geautomatiseerd of gerobotiseerd (zie Tekstbox 6.2). Ook nemen steeds meer bedrijven in de Metalektro gerichte HR maatregelen om vervangingsproblemen te beperken en duurzame inzetbaarheid van hun medewerkers te bevorderen. Metalektrobedrijven proberen de duurzame inzetbaarheid van hun medewerkers vooral te bevorderen met een verdere toename in het gebruik van active aging instrumenten zoals breder inzetbaar maken, aandacht voor de fysieke belasting, het bevorderen van 
een gezonde leefstijl en rekening houden met de leeftijdsopbouw van het personeel bij de werving van nieuwe medewerkers. Bijna het hele scala aan active aging instrumenten werd in 2014 door meer bedrijven toegepast dan in 2013 (Figuur 6.5). Om de problemen bij de vervanging van technici die met pensioen gaan te beperken wordt ook een scala aan HR maatregelen genomen zoals het aannemen en zelf opleiden van nieuw personeel, breder inzetbaar maken van werknemers door taakroulatie, aannemen van al goed opgeleide werknemers, etc. Ook van deze instrumenten verwachten steeds meer bedrijven dat ze er de komende 5 jaar gebruik van gaan maken (Figuur 6.6). Gelijktijdig met de toenemende inzet van HR maatregelen en active-aging instrumenten, zien we dat steeds meer bedrijven proactief vacatures openen in verband met personeel dat binnenkort met pensioen gaat.

\subsection{Concluderend: In de ontwikkeling naar een 'smart industry' neemt de rol van de HR afdeling toe}

Bij verschillende van de hierboven beschreven ontwikkelingen zien we dat er een toenemende rol is weggelegd voor de HR afdelingen van de metalektrobedrijven. Dit geldt voor:

- De upgrading van het personeel, zowel vaktechnisch als PROFI skills.

- Het initiatief voor het volgen van trainingen.

- Het creëren van een leerrijke werkomgeving.

- Het inzetten van active-aging instrumenten.

- HR maatregelen om vervangingsproblemen te voorkomen.

- Het proactief vacatures openen.

Door de cruciale rol die het human capital speelt in de beweging naar een 'smart industry' zal de rol van de HR afdeling de komende jaren alleen nog maar toenemen en zal de concurrentiekracht van de bedrijven in de Metalektro in toenemende mate worden bepaald door de professionaliteit van het gevoerde HR-beleid. HR afdelingen in metalektrobedrijven zullen, analoog aan de R\&D voor technologische innovaties, steeds meer aandacht moeten hebben voor een eigen Research \& Development (R\&D) voor sociale innovatie. Deze sociale innovatie zal gericht moeten zijn op de grote uitdagingen waar het human capital-beleid in de Metalektro voor staat:

- het aantrekken en binden van medewerkers met de technische kwaliteiten, PROFI skills en persoonlijkheid die bedrijven nodig hebben om hun concurrentiekracht te versterken;

- het creëren van een leerrijk werkklimaat (zie de actiepunten hieronder) en verdergaande co-creatie op het gebied van levenslang leren in de regio en de keten, als ook met het beroepsonderwijs;

- het op peil houden van de kennis en vaardigheden van de flexibele schil. 
Hieronder staan een aantal concrete initiatieven die behulpzaam kunnen zijn om deze grote uitdagingen aan te gaan.

\section{Richt de werkomgeving in op leren}

Creëer een optimale leerrijke werkomgeving. Dit kan langs de volgende wegen worden gerealiseerd:

- Geef medewerkers een goed beeld van de mogelijke loopbaanperspectieven.

- Creëer functies met uitdagende taken gekoppeld aan de loopbaanfase.

- Bevorder de samenwerking op de werkvloer en betrek de medewerkers bij de vernieuwingsprocessen.

- Stimuleer functieroulatie en taakroulatie.

- Geef medewerkers positieve en kritische feedback.

- Stimuleer wederzijdse coaching tussen jonge en oudere medewerkers.

- Organiseer (lunch)seminars of praktijkworkshops met interne en externe sprekers over nieuwe ontwikkelingen in de vakgebieden van medewerkers.

- Bied medewerkers de mogelijkheid om verlof in te zetten voor een door het bedrijf gefaciliteerde sabbatical week, waarin medewerkers zich vanuit een ander of ruimer perspectief op hun werk of loopbaan kunnen oriënteren.

- Betrek medewerkers bij innovaties van producten, processen en de sociale interactie in de organisatie, en stimuleer initiatieven van onderaf en bijdragen hieraan vanuit alle lagen van de organisatie.

- Stimuleer medewerkers te participeren in externe professionele (sociale) netwerken.

\section{Verdere professionalisering van het HR-beleid}

Een verdere professionalisering van het HR-beleid moet leiden tot een hoogwaardig human capital beleid, door:

- het human capital beleid van het bedrijf in te bedden in een R\&D-beleid gericht op sociale innovatie (vergelijkbaar met de wijze waarop R\&D de basis vormt voor technologische innovaties);

- het vergroten van de samenwerking met kennisinstellingen die bedrijven kunnen ondersteunen in dit human capital beleid.

\section{Werk aan de continue ontwikkeling van zowel vast als tijdelijk personeel}

- Werk samen met de uitzend- en detacheringsbranche en met andere bedrijven (in de regio) om de duurzame inzetbaarheid van de flexibele schil op peil te houden. 